INTER NATIONAL MONETARY FUND
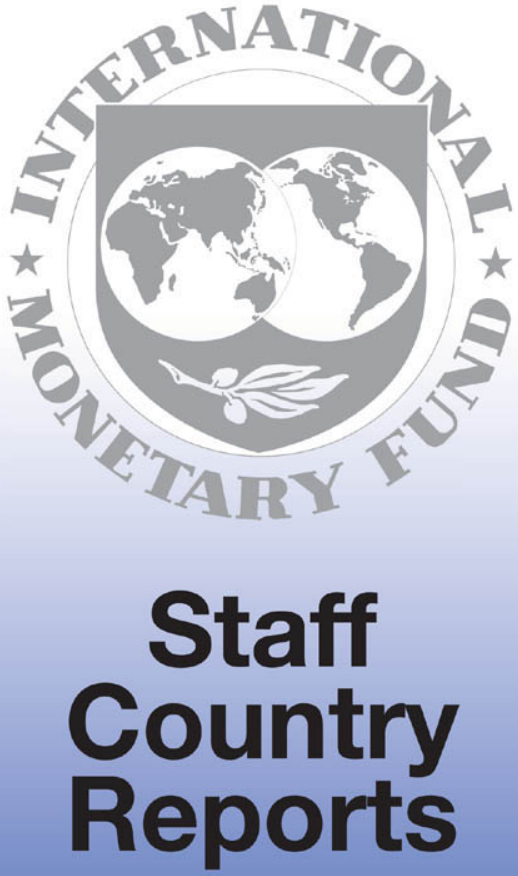


\section{Republic of Belarus: Recent Economic Developments and Selected Issues}

This Recent Economic Developments and Selected Issues report on Republic of Belarus was prepared by a staff team of the International Monetary Fund as background documentation for the periodic consultation with this member country. As such, the views expressed in this document are those of the staff team and do not necessarily reflect the views of the government of Republic of Belarus or the Executive Board of the IMF.

Copies of this report are available to the public from

International Monetary Fund • Publication Services

700 19th Street, N.W. • Washington, D.C. 20431

Telephone: (202) 623-7430 - Telefax: (202) 623-7201

Telex (RCA): 248331 IMF UR

E-mail: publications@imf.org

Internet: http://www.inf.org

Price: $\$ 15.00$ a copy

International Monetary Fund

Washington, D.C. 


\section{INTERNATIONAL MONETARY FUND}

\section{REPUBLIC OF BELARUS \\ Recent Economic Developments and Selected Issues \\ Prepared by Messrs. Schipke, Mumssen, Zeuner, Horton, Ms. Fisher (all EU2); and Mr. Taylor (MAE) \\ Approved by the European II Department}

September 28,2000

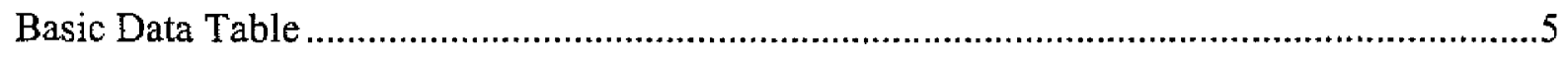

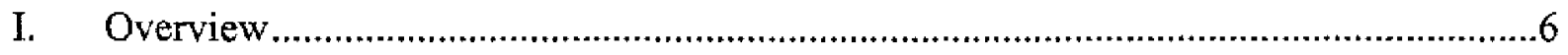

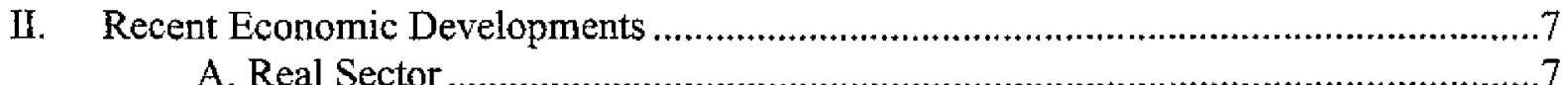

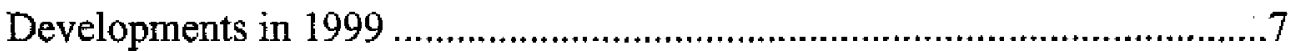

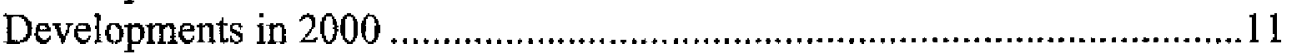

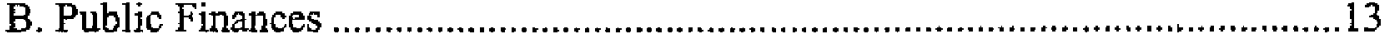

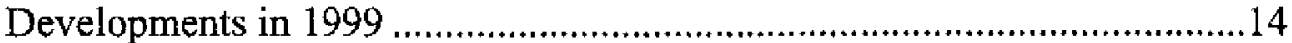

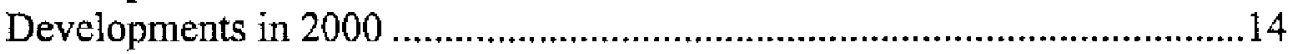

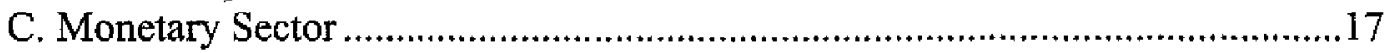

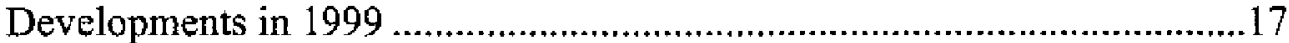

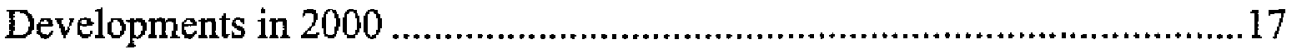

D. External Sector .....................................................................................20

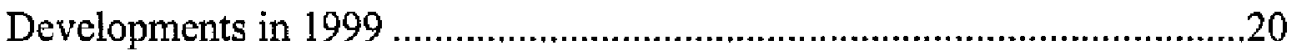

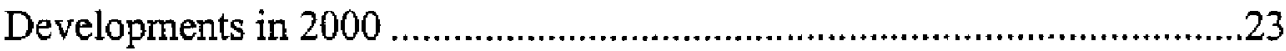

Exchange rate developments.................................................................24

E. Structural Policies.....................................................................................24

III. An Assessment of Banking Sector Vulnerabilities ..................................................26

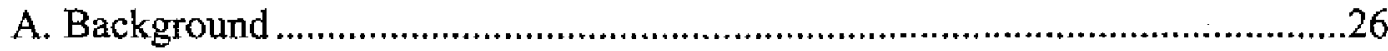

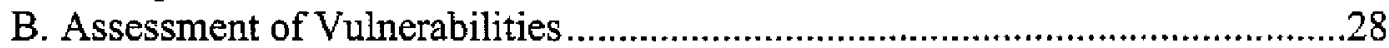

C. Regulatory Environment and Banking Supervision..........................................32 


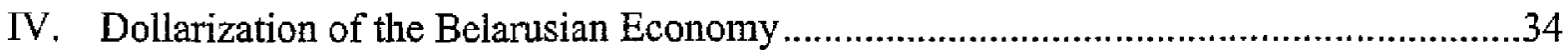

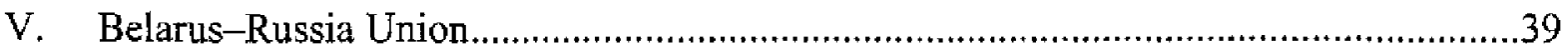

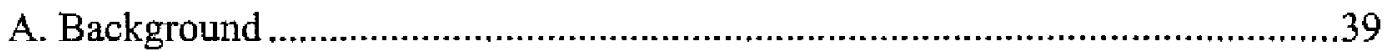

B. Interstate Agreements and Institutions ........................................................39

Economic integration ........................................................................40

Customs harmonization ....................................................................40

Tax harmonization ..............................................................................4

Monetary union ................................................................................42

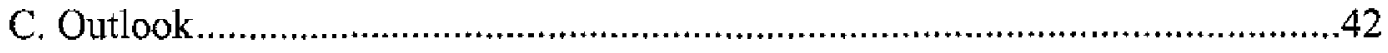

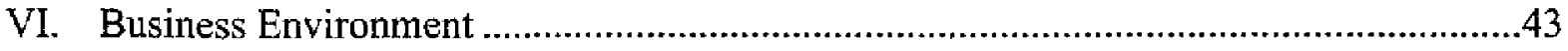

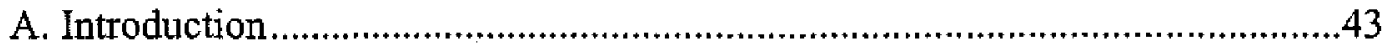

B. Barriers to Private Sector Growth ..................................................................44

Price and wage controls ..........................................................................44

Controls on foreign trade and exchange ....................................................45

Administrative controls ..........................................................................46

State intervention and legal environment ..................................................47

C. Privatization and Foreign Investment …........................................................47

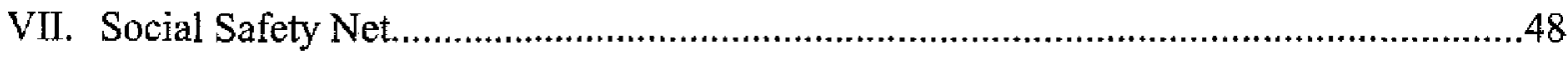

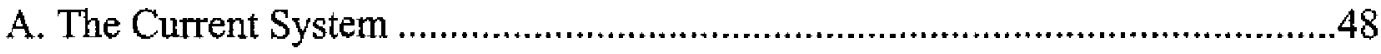

B. The Reform Agenda ................................................................................51

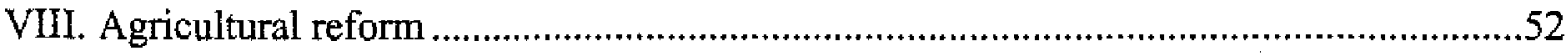

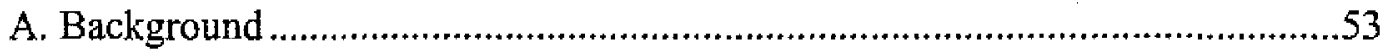

B. Land Reform and the Development of Private Farming ...................................54

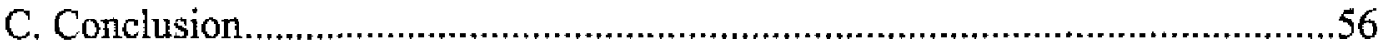

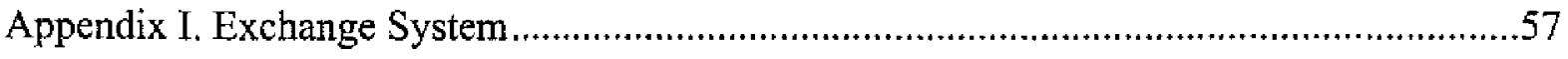

Text Boxes

1. The Budget Sector Wage Grid and Wage Indexation in Belarus ............................13

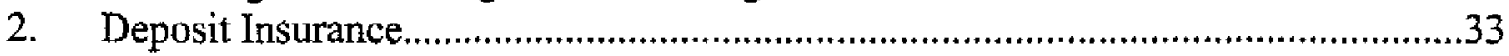

$\underline{\text { Text Figures }}$

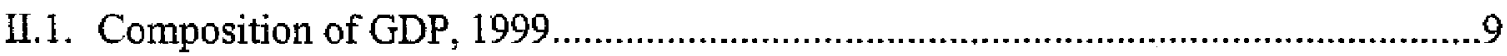

II.2. Inflation and Wages in Selected CIS Countries, January 1995-June 2000 _............10

II.3. Fiscal Operations, 1998-2000 …................................................................16

II.4. Interest Rates, January 1996-June 2000 _......................................................19

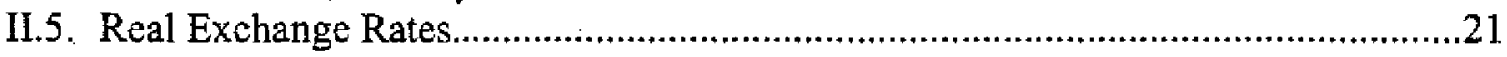

II.6. Share of CIS Countries and Russia in Total Trade, 1993-99 …............................22 


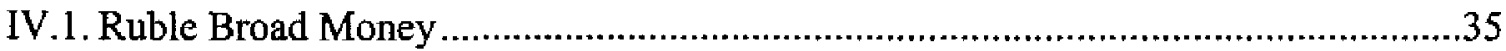

IV.2. Interest Rate on Foreign Currency Deposits, 1996-2000 _.................................36

IV.3. Real Domestic Currency Deposit Rate, 1996-2000 .............................................36

IV.4. Foreign Exchange Deposits at Commercial Banks...................................................36

IV.5. Foreign Exchange Deposits and Inflation...................................................................37

IV.6. Minimum Reserve Requirements .......................................................................38

$\underline{\text { Text Tables }}$

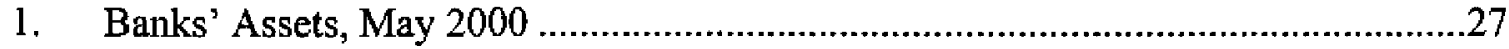

2. Commercial Bank Loans by Economic Sector, 1995-99 ......................................30

Appendix Tables

1. Gross Domestic Product by Sector, 1995-99 …….............................................59

2. Gross Domestic Product by Expenditure, 1995-99 _.............................................60

3. Growth of Gross Domestic Product by Expenditure, 1995-99 _............................61

4. Growth of Gross Domestic Product by Sector, 1995-99 …....................................62

5. Capital Investment by Sector in Comparable Prices, 1995-99.............................63

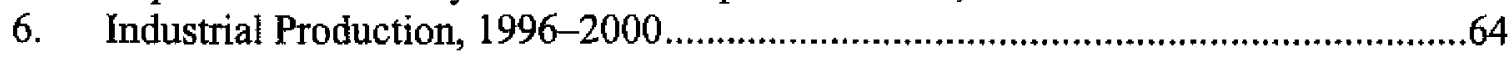

7. Inventories of Final Products in the Warehouses of Industrial Enterprises

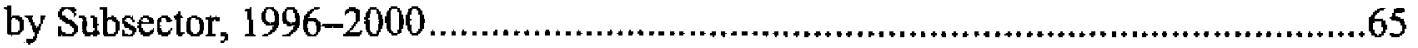

8. Agricultural Production, 1995-99 …..........................................................66

9. Production and Consumption of Energy, 1995-99 _..............................................67

10. Change in Consumer and Producer Prices 1996-2000 ...........................68

11. Changes in Administered Prices of Household Services, 1999-2000 _....................69

12. Tariffs and Cost Coverage for Households, 1998-2000 _.......................................70

13. Average Monthly Wages 1995-99 _..................................................................71

14. Price and Wage Developments, 1996-2000 ….................................................72

15. Money Income and Expenditures of the Population, 1996-2000 ........................73

16. Labor Market Indicators, 1996-2000 ..........................................................74

17. Average Monthly Employment by Sector, 1996-2000 …....................................75

18. Enterprise Profits and Losses, 1996-2000 _..........................................................76

19. Interenterprise Arrears and the Barter Economy, 1996-2000 .............................77

20. Sectoral Distribution of Energy Debts of Enterprises, 1997-1999..........................78

21. General Government Operations, 1996-2000 (in millions of rubels) ....................79

22. General Government Operations, 1996-2000 (in percent of GDP) ........................80

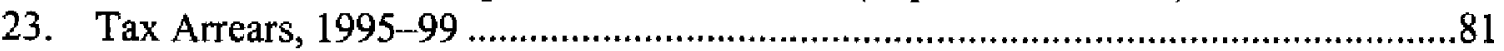

24. General Government Debt, 1996-2000 ….........................................................82

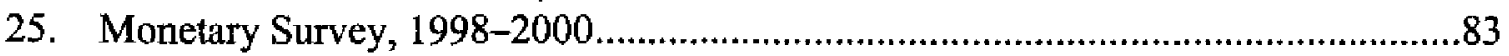

26. Accounts of the National Bank of Belarus, 1998-2000 .......................................84

27. Deposit Money Banks' Accounts, 1998-2000 …...............................................85

28. National Bank's Directed Credits, 1997-2000 _..................................................86

29. Composition of Bank Lending by Type of Credit and Sector, 1996-2000 …..........87

30. Auction of Securities issued by the Ministry of Finance, 1999-2000 .....................88 


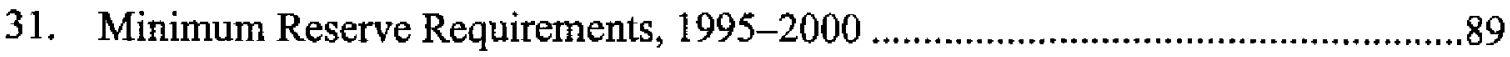

32. Interest Rates of the National Bank of Belarus, 1999-2000 ..................................90

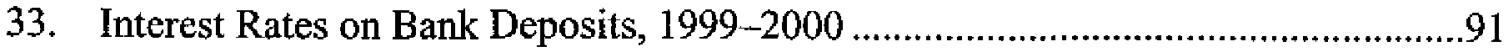

34. Interest Rates on Bank Credit, 1999-2000 .....................................................92

35. Interest Rates on New Foreign Exchange Credits and Deposits, 1999-2000..........93

36. Structural Characteristics of the Banking Sector, 1997-2000 .............................94

37. Commercial Banks, Selected Indicators, 1996-2000 ....................................95

38. Six Largest Commercial Banks, Selected Indicators, 1996-2000 ........................96

39. Commercial Banks and Branches of Foreign Banks ........................................97

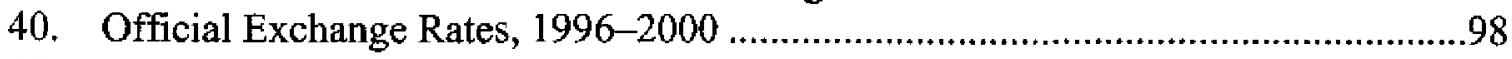

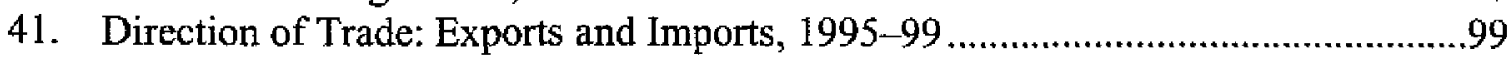

42. External Trade in Goods by Economic Branches, 1996-99 ..........................100

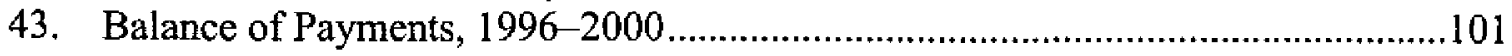

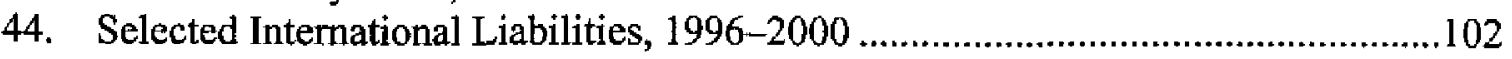

45. Disbursements and Payments on Medium- and Long-term Public and

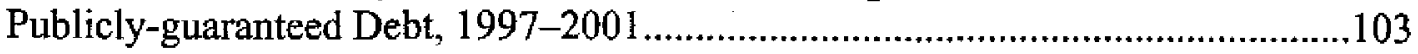

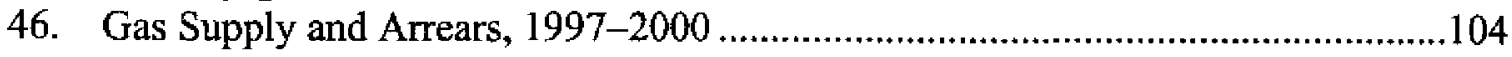

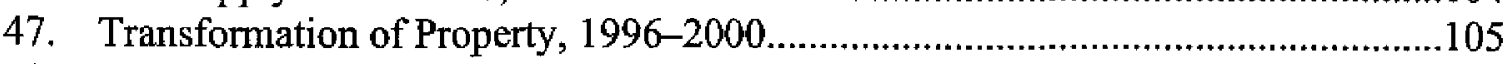

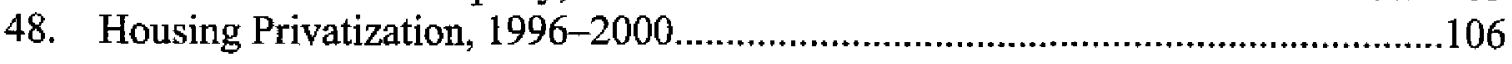


Belanus: Basic Data, 1995-2000 (June)

\begin{tabular}{|c|c|c|c|c|c|c|c|}
\hline & 1995 & 1996 & 1997 & 1998 & 1999 & \multicolumn{2}{|l|}{2000} \\
\hline & & & & & & Q1 & Jan-Jun \\
\hline \multicolumn{8}{|l|}{ Social and derrographic indicalors } \\
\hline Population (in thousands) & 10,246 & 10,235 & 10,300 & 10,179 & 10,019 & 10,009 & $\ldots$ \\
\hline UIban & 7,061 & 7,071 & 7,214 & $\ldots$ & 6,985 & $\ldots$ & $\ldots$ \\
\hline Rural & 3,236 & 3,793 & 3,869 & $\ldots$ & 3,034 & $\ldots$ & $\ldots$ \\
\hline Population density (inhabitants per sq. km.) & 50 & 49 & 49 & $\ldots$ & 48 & 48 & $\ldots$ \\
\hline Life expectancy at birth (in years) & 68.6 & $\ldots$ & 69.0 & $\ldots$ & 67.9 & $\ldots$ & $\ldots$ \\
\hline [nfant mortality rate (per thousand) & 13.3 & 12.6 & 12.1 & $\ldots$ & 11.5 & 9.2 & $\ldots$ \\
\hline Annual population growth rate (in percent) & -0.3 & -0.3 & 0.6 & -1.2 & -0.3 & $\ldots$ & $\ldots$ \\
\hline GDP (in millions of U.S. dollars) $1 /$ & 10,389 & 13,857 & 13,595 & 14,555 & 11,561 & 3,266 & 6,349 \\
\hline \multirow[t]{2}{*}{ GDP per capita (in U.S. dollars) U } & 1,014 & 1,354 & 1,320 & 1,430 & 1,154 & $\cdots$ & $\cdots$ \\
\hline & \multicolumn{7}{|c|}{ (Percentage changes in constant prices) } \\
\hline \multicolumn{8}{|c|}{ 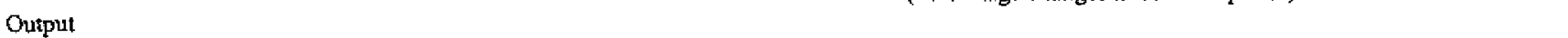 } \\
\hline GDP & -10.4 & 2.8 & 1.4 & 8.4 & 3.4 & 6.1 & 4.0 \\
\hline \multicolumn{8}{|l|}{ Of which: } \\
\hline Inciustry & -10.2 & 4.1 & 16.5 & 8.7 & 8.3 & 6.0 & 5.6 \\
\hline Agriculture & -2.5 & 1.4 & -5.9 & -0.9 & -9.1 & -9.2 & -7.5 \\
\hline \multirow[t]{2}{*}{ Industrial production } & -11.7 & 3.5 & 18.8 & 12,4 & 10.3 & 7.5 & 5.6 \\
\hline & \multicolumn{7}{|c|}{ (Percentage changes) } \\
\hline \multicolumn{8}{|l|}{ Prices and Wages } \\
\hline Producer prices (end-of-period; year-on-year) & 122 & 31 & 91 & 200 & 239 & 168 & 190 \\
\hline Consumer prices (end-of-period; year-on-year) & 244 & 39 & 63 & 182 & $2 \$ 1$ & 212 & 191 \\
\hline Average wage, excluding kolkhozes & 669 & 61 & 88 & 105 & 250 & 289 & 202 \\
\hline \multirow[t]{2}{*}{ Minimum wage (end-of-period; year-on-year) } & 200 & 67 & 100 & 75 & 4,043 & 2,800 & 1,350 \\
\hline & \multicolumn{7}{|c|}{ (In U.S. dollars) } \\
\hline Average monthly wage (end-of-period) $1 /$ & 88 & 103 & 108 & 83 & 110 & 107 & 92 \\
\hline \multirow[t]{2}{*}{ Minimum wage (end-of-period) $1 /$} & 5 & 6 & 7 & 4 & 46 & 34 & 23 \\
\hline & \multicolumn{7}{|c|}{ (In percent of GDP) } \\
\hline \multicolumn{8}{|l|}{ General goverument finance $2 i$} \\
\hline Revenue & 31,0 & 30.0 & 29.0 & 44.5 & 45.7 & 52.3 & 37.9 \\
\hline Expenditure 3/ & 33.7 & 31.6 & 29.6 & 44.8 & 49.7 & 55.0 & 40.3 \\
\hline \multirow[t]{2}{*}{ Balance $3 /$} & -2.7 & -1.6 & -0.6 & -0.3 & -2.2 & -2.7 & -2.4 \\
\hline & \multicolumn{7}{|c|}{ (Percentage changes from previous period) } \\
\hline \multicolumn{8}{|l|}{ Money and credit } \\
\hline Rubel broad money & 292 & 67 & 103 & 130 & 195 & 195 & 172 \\
\hline Banking system net domestic credit 4 & 160 & 59 & 116 & 300 & 143 & 174 & 216 \\
\hline \multirow[t]{2}{*}{ Refinance rate (percent per annum, end-of-period) } & 66 & 35 & 42 & 48 & 120 & 150 & 90 \\
\hline & \multicolumn{7}{|c|}{ (In millions of U.S. dollars; unless otherwise indicated) } \\
\hline \multicolumn{8}{|l|}{ Merchandise trade } \\
\hline Exports of goods & 4,803 & 5,790 & 7,383 & 7,138 & 5,949 & 1,679 & $\ldots$ \\
\hline Imports of goods & $-5,469$ & $-6,939$ & $-8,718$ & $-8,488$ & $-6,548$ & $-1,975$ & $\ldots$ \\
\hline Trade bafance & -666 & -1.149 & $-1,335$ & $-1,350$ & -599 & -296 & $\ldots$ \\
\hline Current account balance (in percent of GDP) & -4.4 & -3.7 & -5.8 & -5.9 & -2.0 & -4.1 & $\ldots$ \\
\hline Exchange rate (in rubels per U.S. dollar, end-of-period) $5 /$ & 12 & 16 & 31 & 107 & 320 & 434 & 675 \\
\hline (in rubels per U.S. dollar; period average) & 12 & 13 & 26 & 46 & 250 & 382 & $45 ?$ \\
\hline Goss convertible official reserves & 377 & 369 & 394 & 345 & 309 & 294 & 367 \\
\hline
\end{tabular}

Sources: Belarusian authorities; and IBRD.

1/ Measured at the official exchange rate.

2/ Based on data according to the functional classification. Data for the first half of 2000 refer to preliminary data for January-May, excluding the Social Protection Fund.

$3 /$ Includes an adjustment for discrepancy between monetary and fiscal data.

4/ Unadjusted for exchange rate variation.

5/ Data have been revised backward to reflect the redenomination of the rubel on January 1,2000 , which removed three zeros from the currency. 


\section{OVERVIEW}

1. The government continues to control or intervene in most aspects of the Belarusian economy. This is done either directly, through the ownership of productive assets and banks, or indirectly, through the channeling of resources to priority sectors and pervasive administrative controls. Government intervention has inhibited the development of a dynamic private sector. It also clouds the analysis of fiscal developments. While officiallyrecorded fiscal deficits have been relatively low over the past few years, monetary policy has traditionally accommodated the financing of strategic but inefficient sectors of the economy, such as agriculture. Therefore, the officially-measured fiscal deficit becomes a poor measure of the extent of fiscal activities.

2. Given Belarus' relative openness and extreme dependence on Russian markets, economic activity slowed down substantially in the aftermath of the Russian crisis, with output growth falling from about $81 / 2$ percent in 1998 to $31 / 2$ percent in 1999 . With the slowdown in external and domestic demand, both exports and imports contracted substantially, resulting in a drop of the current account deficit from 6.1 percent of GDP in 1998 to 2.2 percent of GDP in 1999 . The authorities responded by relaxing monetary policy. Despite the continued use of price and exchange rate controls, this policy led to an acceleration in inflation (to about 250 percent at the end of 1999) and a depreciation of exchange rates in the parallel markets. There was little progress with respect to structural reforms in 1999 , especially regarding price liberalization and privatization.

3. Faced with an increasingly destabilized macroeconomic environment, at the end of 1999 , the authorities set out to change their economic policy stance, seeking to reduce inflation and to unify the multiple exchange rates at a gradual pace. Their economic program for 2000 targeted an end-period inflation rate of 90 percent, and output growth of 3 percent. To achieve these objectives, the authorities aimed to limit the average growth rate of rubel broad money to 4 percent per month and the annual fiscal deficit to 1.7 percent of GDP.

4. Compared to the original economic program, the results for the first half of 2000 were mixed. Largely driven by the strong recovery of Belarus' largest trading partner, Russia, output grew by 4 percent. The faster depreciation of the official exchange rate and several steps toward liberalizing the parallel foreign exchange market led to a significant narrowing of the spread between official and parallel rates (from 180 percent at the beginning of the year to about 25 percent by end July). The tightening of monetary policy at the beginning of 2000 was associated with a return to positive real interest rates. However, while inflation has come down (end-period inflation was 54 percent during the first half of the year compared to 86 percent during the same period in 1999), the National Bank of Belarus (NBB) relaxed its

\footnotetext{
${ }^{1}$ The National Bank of Belaris merged the main and additional trading sessions at the Belarusian Currency and Stock Exchange in mid-September, and announced that, from then on the official rate would be determined by supply and demand.
} 
monetary policy again in the second quarter of 2000 in order to accommodate a government's directive for commercial bank lending to the agricultural sector. As a result, rubel broad money grew by 7.6 percent on average per month during the first half of 2000 , substantially exceeding the authorities' original target. The fiscal position was also weaker than anticipated. With revenues performing below budget, the adjusted general government deficit for the first five months of the year (including quasi-fiscal operations) reached 2.4 percent of GDP. ${ }^{2}$ At the same time, the government faced difficulties in financing its operations and had to cut expenditures. While there was less external financing than anticipated, banks' tighter liquidity position during the first half of the year complicated the placement of domestic debt instruments.

5. The remaining sections are organized as follows: Chapter II covers recent economic developments through the first half of 2000 . Chapter III provides an assessment of vulnerabilities in the Belarusian banking system, also taking into account the potential shortterm impact of a tightening of monetary and fiscal policies as well as exchange rate unification. Chapter IV discusses dollarization in Belarus. Chapter V describes recent developments toward the creation of an economic union with Russia.

6. The long-term growth prospects for Belarus will depend-to a large extent-on the creation of an environment that is conducive to private sector activity, entrepreneurship, and investment, including by foreigners. Chapter VI describes the current business environment and the existing obstacles to reach these objectives. Chapter VII describes key aspects of the current safety net, its shortcomings, and the government's reform effort. Agriculture plays a key role in the Belarusian economy. As in other parts of the economy, the involvement of the government in the sector is large. Chapter VIII describes the lack of progress in agricultural reform, especially with respect to land reform and the development of private sector farming.

\section{RECENT ECONOMIC DEVELOPMENTS}

\section{A. Real Sector}

\section{Developments in 1999}

\section{Overall economic activity}

7. Economic activity slowed down markedly in 1999. Real GDP expanded by only $31 / 2$ percent, compared to $81 / 2$ percent in 1998 and $11 \frac{1}{2}$ percent in 1997 . Year-on-year growth was sluggish during the first quarter ( $1 \frac{1}{2}$ percent) but gained pace toward the end of the year, reaching $6 \frac{1}{2}$ percent during the fourth quarter.

\footnotetext{
${ }^{2}$ This figure excludes the Social Protection Fund.
} 
8. A combination of domestic and external factors affected output growth in 1999 . Extemally, exports to Russia, which accounted for more than 50 percent of total exports, fell sharply during the second half of 1998 , in the wake of the Russian crisis. Demand for Belarusian products was weak throughout 1999, showing signs of recovery only during the final quarter, with the revival of economic activity in Russia. Domestically, positive growth was maintained by a continuation of government-directed programs to boost consumption and an expansionary monetary policy. Public consumption increased by 2 percent and private consumption by 5 percent in real terms compared to 1998 . However, capital investments could not be stimulated sufficiently by the country's strategy of money-led growth. After two years of double-digit growth, gross capital formation fell by almost 14 percent in 1999 , including a significant reduction in the stock of inventories. Net of the change in inventories, capital investments fell by $5 \frac{1}{2}$ percent.

9. The industrial sector was the major source of output growth in 1999 given its large share in GDP (Figure II.1). Industrial value added expanded by almost $81 / 2$ percent, while construction stagnated at the 1998 level, despite extensive lending programs for housing. Trade grew by more than 9 percent year-on-year, followed by the transport sector, which grew by about 3 percent during the same period. By contrast, agriculture contracted by 9 percent in 1999, as Belarus experienced its second consecutive bad harvest. Within industry, machine-building, metalworking, wood-working and the food industry were the main contributors to Belarus' growth performance in 1999, with value added growth reaching double-digits. While the decline of the agricultural sector was partly due to bad weather conditions, it also reflected a steady deterioration of the capital stock, and the distorted incentive structure in the sector (price controls, collective farming, and stateownership of land). ${ }^{3}$ With the exception of 1996 , agricultural output has been falling since 1993.

${ }^{3}$ For a more detailed analysis, see Chapter VIII. 
Figure H.1. Belarus: Composition of GDP, 1999

(In percent)

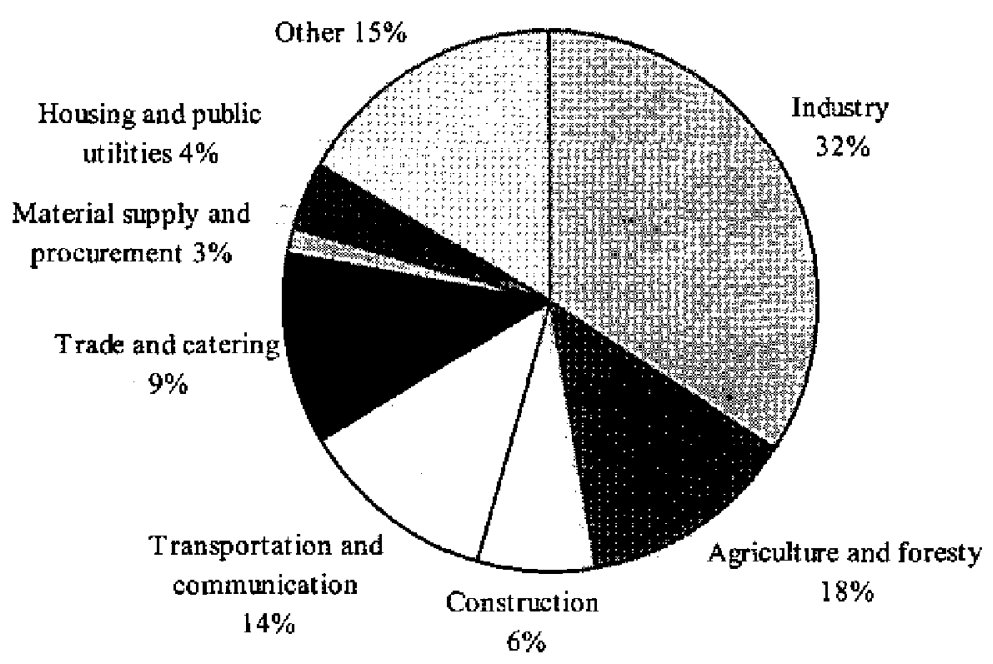

Source: Belarusian authorities.

\section{Inflation}

10. Output growth in 1999, however moderate, came at the expense of high inflation, notwithstanding extensive price controls. The twelve-month rate of consumer price inflation remained at triple digits (251 percent) at end-December, with consumer price inflation for the year as whole averaging 294 percent. This was well above average consumer price inflation in 1998 ( 73 percent) and 1997 (64 percent) and compares unfavorably with inflation performance in neighboring CIS countries (Figure II.2).

11. High and rising inflation was primarily the result of Belarus" expansionary monetary and credit policies. Furthermore, whereas in the past the economy could run a current account deficit that partially absorbed inflationary pressures generated by the expansionary monetary policy, during most of 1999 access to import financing to partially offset excess demand was not available due to the Russian crisis. Despite continued exchange controls, price pressures also resulted from a sharp depreciation of the rubel against the U.S. dollar in nominal terms in 1999 , both in the official and parallel markets. Finally, inflation was also fueled ex-post by wage adjustments intended to offset losses in real houschold income.

\section{Wages}

12. For the fourth consecutive year, real wages (adjusted for CPI increases) were raised with a view toward restoring the level of real income achieved during the Soviet era. In 1999 , period average real wages grew by about 4 percent year-on-year, which was again achieved through backward-looking wage indexation for low income groups and several adjustments 
Figure II.2. Belarus: Inflation and Wages in Selected Countries, January 1995-June 2000

Average Monthly Wages

(In U.S. dollars)

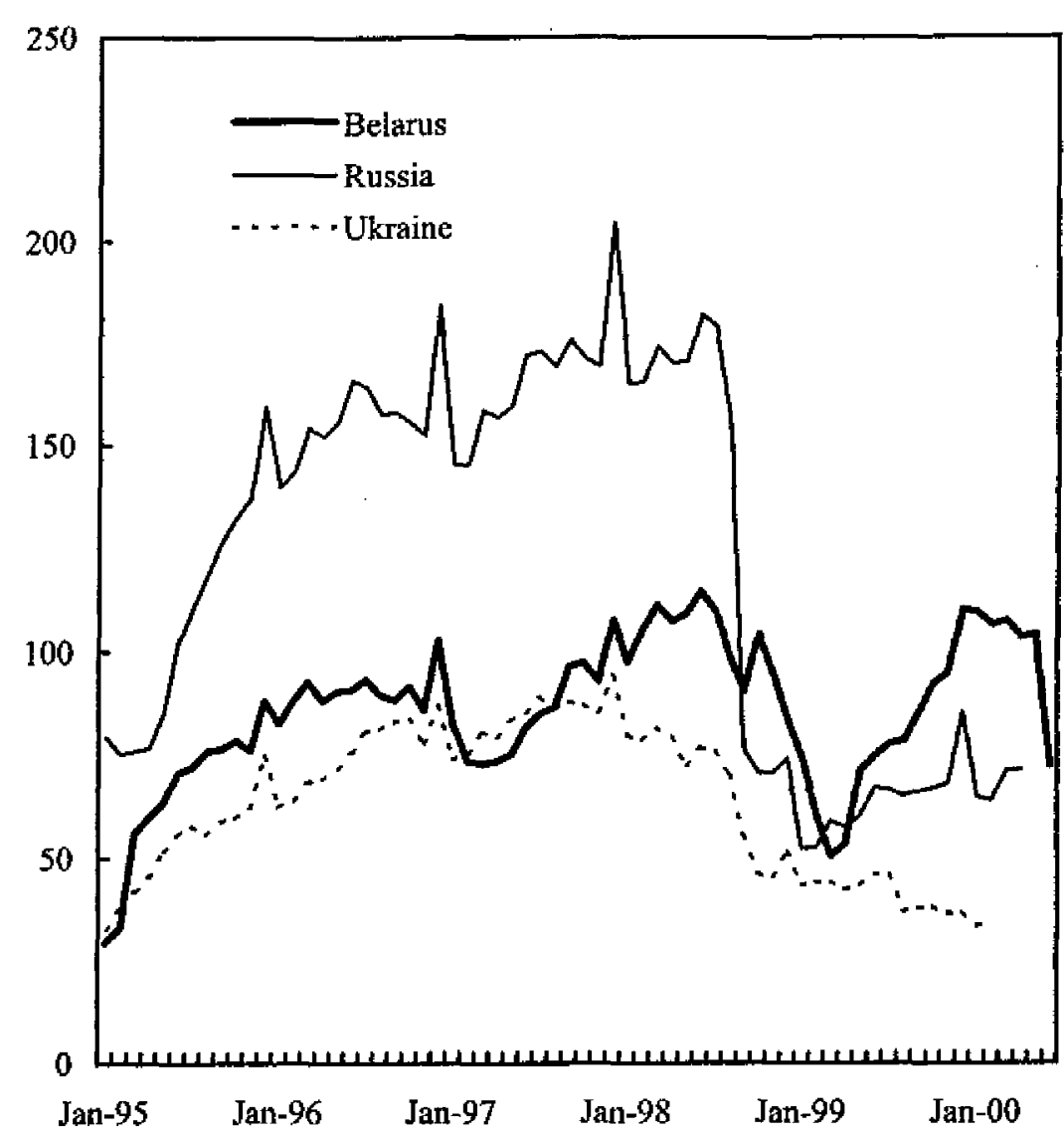

Consumer Price Inflation

(Monthly percent change)

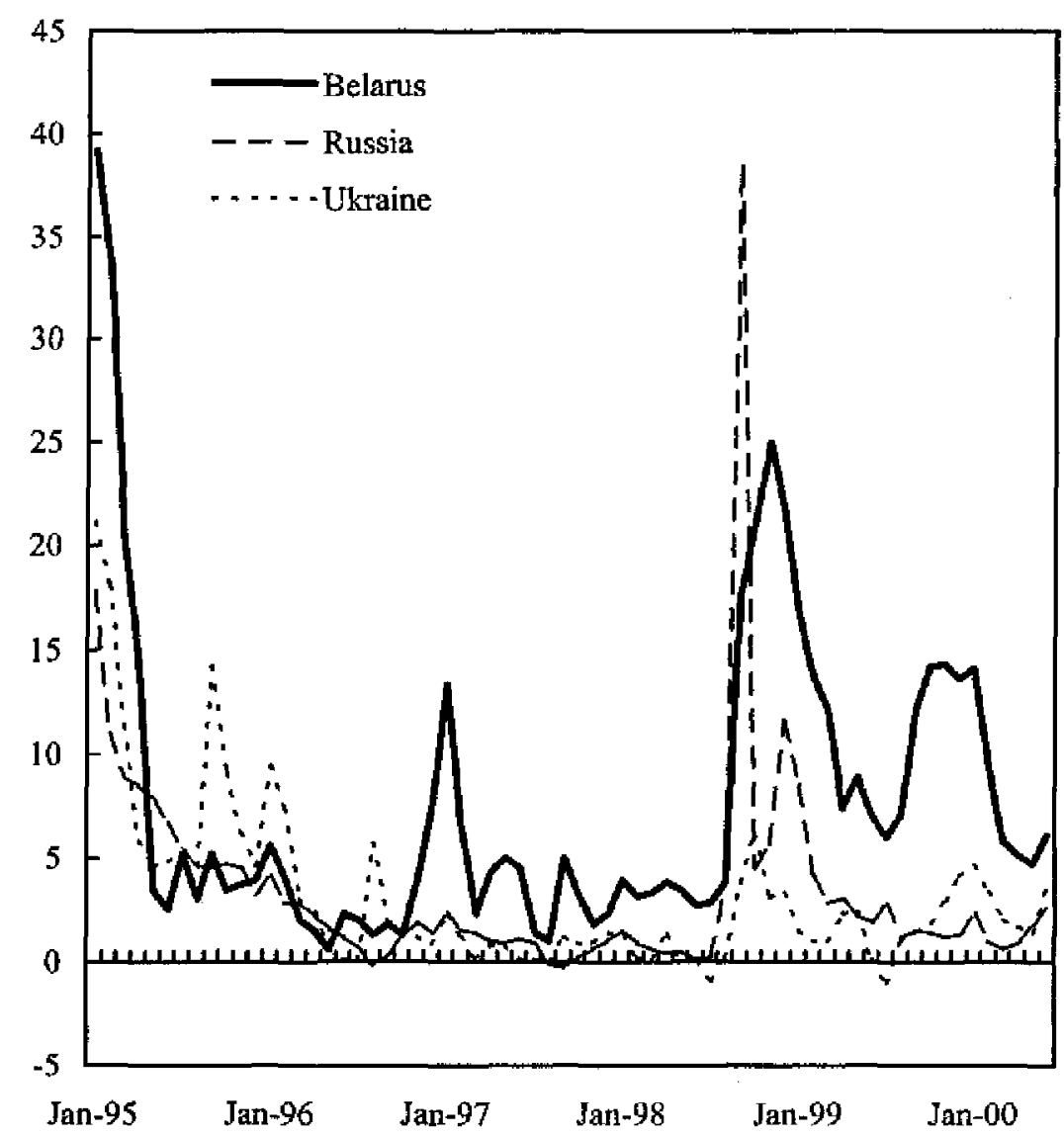

Source: Belarusian authorities; and Fund staff estimates. 
in all other public sector wages in the economy. The latter were raised by 35 percent each time, in January, May, and in several smaller steps during October-December 1999. The average nominal monthly wage in the public sector, therefore, rose by 277 percent compared to 1998 , reaching $\mathrm{Rbl} 24,000$ or $\$ 41$ (measured at the parallel exchange rate). ${ }^{4}$

13. Wage developments in the public sector put considerable pressure on private sector wage policies, including parastatals. The private sector average nominal monthly wage rose by about 320 percent during 1999 and reached the level of Rbl 19,500 or $\$ 33$ (measured at the parallel exchange rate).

14. Despite considerable wage increases during the year, the salaries in some sectors, including agriculture and social services, were below subsistence level at end-December 1999. Moreover, a positive increase in public and private sector rubel real wages masked a stagnation in living standards. In U.S. dollar-terms, period average wages in the economy as a whole fell to $\$ 34$ from $\$ 50$ in the previous year (measured at the parallel exchange rate).

15. Formal unemployment, as registered at local labor exchanges, was reported at 2 percent for 1999, roughly unchanged from the 1998 level. However, estimates suggest that hidden unemployment is much higher in Belarus, reaching at least 10 percent, with considerable regional variations. Unemployment benefits amounted to $\mathrm{Rbl} 5,200$ or $\$ 5$ per month (measured at the parallel exchange rate) in May 2000, falling significantly short of the prevailing minimum subsistence budget of Rbl 39,000.

\section{Enterprise profitability}

16. Continued price controls on both products and producers, and the distortions in the exchange rate system worsened enterprises' financial position during 1999 following some relief toward the end of 1998. The hike in the international price of oil and the continued government-directed diversion of funds to agriculture and housing also contributed to the deterioration of enterprises' balance sheets. The number of loss-making enterprises increased by 6 percent in 1999 , to 17 percent of the total. Furthermore, interenterprise arrears remained high, at $371 / 2$ percent of GDP. Against this background, output levels continued to be maintained through barter transactions, often associated with implicit subsidies in the agreedupon relative price.

\section{Developments in 2000}

17. During January-June 2000, real GDP grew by 4 percent, compared to the same period last year. Industry was again the driving force behind growth ( $51 / 2$ percent). At the same time, agriculture continued to contract (minus $7 \frac{1}{2}$ percent), making it increasingly

\footnotetext{
${ }^{4}$ The parallel rate used as reference is the domestic non-cash interbank rate outside the Belarus Currency and Stock Exchange.
} 
unlikely that the sectoral growth target for the year as a whole ( $8-9$ percent) will be achieved despite continued financial support to the sector. Transportation also fell by $151 / 2$ percent during the first half of the year, while retail trade turnover and the service sector expanded by about 11 percent and 1 percent, respectively.

18. On the expenditure side, exports started growing again in the first half of 2000 , following the recovery of the Russian economy. Due to high oil prices, however, the trade balance deteriorated sharply. Investments grew by $4 \frac{1 / 2}{2}$ percent, in line with overall GDP growth, this time reflecting the build-up of significantly larger stocks (100 percent growth during January-May). Preliminary estimates suggest that consumption was up by about $61 / 2$ percent. An expansion of housing construction by more than $251 / 2$ percent reflected continued large-scale directed lending programs in this area.

19. Consumer prices rose by 8 percent per month on average during January-June 2000 , compared to 11 percent in 1999 . On cumulative terms, consumer price inflation rose to 54 percent during the same period. As in the previous year, high inflation reflected Belarus' loose monetary policy stance and exchange rate depreciation, while high international oil prices also added pressure on prices. Mandatory ceilings on monthly price increases ranging from 5 to 17 percent for different products may also have fueled inflation. As long as the average monthly inflation is below the ceiling, this administrative measure provides enterprises with the incentive to make precautionary price adjustments. Compared to 1999 , average monthly inflation slowed down somewhat in 2000 , falling from 14 percent in January to 6 percent in June. This partly reflects some tightening of monetary policy and the relative stability in the non-controlled segments of the foreign exchange market.

20. In January and May 2000, the reference wage of the Belarusian wage system was raised by 50 and $151 / 2$ percent, respectively, reaching Rbl 5,200 or $\$ 5$ per month at endMay (see Box 1 for details on the wage system). This level was equivalent to the monthly unemployment benefit at the time, but fell significantly short of the subsistence level budget. ${ }^{5}$ Public sector wages were adjusted accordingly, followed by similar wage increases in the private sector. The average monthly wage reached $\mathrm{Rbl} 60,500$ or $\$ 57$ (measured at the parallel exchange rate) at end-June.

\footnotetext{
${ }^{5}$ The subsistence level budget is equal to the money income that is needed for minimum consumption.
} 


\section{Box 1: The Budget Sector Wage Grid and Wage Indexation}

The Belarusian labor legislation is being reformed at present to reflect the new labor code that was introduced on January 1,2000. A major change currently under review is to require all sectors of the economy to adopt the state wage system, including the rigid budget sector wage grid and wage indexation. In their efforts to reform the wage system, the authorities are concerned both about the low level of real wages in the economy and the possibility that this may reflect cash side payments by enterprises to avoid taxes and social fund contributions.

The budget sector in Belarus comprises some 1 million workers. The wage grid for these employees has 28 grades, each of which is a multiple of the first grade. The first-grade wage was equivalent to Rbl 5,200 or $\$ 5$ (evaluated at the parallel exchange rate) at end-May 2000. Due to high inflation, the first-grade wage is generally reviewed quarterly and has been raised twice so far during 2000 . Since the remaining budget sector wages are expressed in terms of the first-grade wage, both changes have consequently triggered wage adjustments in all of these categories. The rigidity of the budget sector wage system, particularly when adopted for the rest of the economy, is reinforced by the fact that the wage differentials as defined by the grid have to remain constant, which raises costs significantly. Only the entire grid can be moved.

In addition, wage differentials have also started to be compressed by the new system of (still backward-looking) wage indexation in Belarus. In February 2000, the government abandoned the fixed indexation ceiling of $\mathrm{Rbl} 5,000$ below which wages were automatically adjusted for monthly consumer price inflation of more than 5 percent. The authorities realized that a fixed indexation ceiling could not be maintained with still high inflation. Hence, they adopted instead a moving ceiling for indexation of 50 percent of the subsistence level budget, which is periodically adjusted for inflation. At end-June 2000, the subsistence level budget was equal to $\mathrm{Rbl} 26,000$ or $\$ 27$ (evaluated at the parallel exchange rate). Thus, the first-grade wage is equal to only 20 percent of the subsistence level budget and the third-grade wage is the first wage level that can cover minimum consumption. The government is planning to take measures to gradually raise the first-grade wage to the subsistence level budget by 2005 .

The new system leads to wage compression because low-level wages are adjusted fully and more frequently than high-level wages. Under extremely high price pressures, wage compression is accelerated.

\section{B. Public Finances}

21. The continued large role of the government in economic activity and the redistribution of income is reflected in Belarus' high tax burden. General government revenues-including social security taxes-amounted to more than 45 percent of GDP in 1999. The analysis of fiscal developments is clouded by extensive quasi-fiscal operations, which are not included in the budget (more on this below). For example, banks are regularly instructed by the government to provide loans at subsidized interest rates to targeted sectors with a questionable ability to repay. Furthermore, the public sector accounts underestimate the fiscal operations of the government due to the widespread use of cross-subsidization and the accumulation of energy arrears. 


\section{Developments in 1999}

22. The officially recorded general government deficit narrowed from 1.9 percent of GDP in 1995 to 0.3 percent of GDP in 1998. However, the deficit increased again to 2.2 percent in 1999 , largely reflecting budgetary support to two state banks of 2.4 percent of GDP. ${ }^{6}$ Including quasi-fiscal operations, the overall deficit widened to 5.7 percent of GDP, from 3.3 percent of GDP in 1998. In view of negative foreign financing ( 0.3 percent of GDP), the deficit was financed largely through central bank credit (about 2.5 percent of GDP).

23. The deterioration in the general government position in 1999 took place despite an improvement in revenue collection of 1.2 percent of GDP. Payroll taxes improved from 0.9 percent of GDP to 1.6 percent of GDP because local governments were able to levy additional taxes. Other taxes on goods and services increased from 0.4 percent of GDP to 1.9 percent of GDP after local governments started to impose their own sales taxes. During the same period, property taxes fell from 1.3 percent of GDP to 0.6 percent because property values were not revalued in 1999, despite an annual average inflation rate of some 295 percent. Collection of the personal income tax fell from 3.7 percent of GDP in 1998 to 3.1 percent of GDP in 1999, largely as a result of an increase in the nontaxable threshold. A drop in excise taxes from 3.9 percent of GDP to 3.4 percent of GDP was attributed to lower retail sales and the slow depreciation of the official exchange rate, since excises are levied in euros per physical unit.

24. Despite lower capital expenditure in real terms, overall expenditure for the consolidated budget climbed by 3.1 percent of GDP in 1999, mostly on account of support to two state banks. Higher expenditure on housing construction ( 0.9 percent of GDP) and the road fund ( 0.4 percent of GDP), also contributed to magnify overall expenditures.

\section{Developments in 2000}

25. The general government performed poorly during the first five months of the year, posting a deficit of 2.4 percent of the period GDP, compared to a full-year target of 1.7 percent of GDP, reflecting a marked shortfall in revenue. Actual revenue collection amounted to 37.9 percent of GDP for the first five months of the year, compared to the budgeted level of 39 percent of GDP, and 41.7 percent in the same period in 1999. The revenue shortfall can be attributed largely to lower profit and excise taxes reflecting a deterioration in enterprise profitability and lower collection of excises from the sale of gasoline and vodka. Expenditures for the first five months of the year were broadly in line with the level of real expenditures in 1998 and slightly below budget. While both capital expenditure and spending on education exceeded the budgeted amounts, expenditures by

\footnotetext{
${ }^{6}$ The assessment of the banking sector situation presented in Chapter III suggests that the inclusion of the capital support is a more realistic measure of the fiscal position of the general government.
} 
budgetary funds, on social policies and other miscellaneous expenditures fell short of the budgeted levels.

26. The financing of the operations of the government during the first five months of the year was tighter than envisaged in the budget. The faster-than-budgeted depreciation of the official exchange rate ${ }^{7}$ increased the domestic currency equivalent of extemal amortization payments. The burden of the amortization payments was aggravated by the absence of external financing, as originally anticipated inflows of official financing did not materialize. The government also experienced difficulties in placing debt instruments domestically, owing to the tighter liquidity position of the banking system. In addition to the impact of the tighter monetary policy on the banking system's liquidity, especially at the beginning of the year, banks' liquidity situation was affected by their continued quasi-fiscal operations, including mandatory lending to the agricultural sector (see Chapter III). While direct credit from the NBB was in line with the budgeted target for the year of Rbl 76 billion, the government reduced its deposits with the NBB to finance its operations.

\section{Quasi-fiscal operations}

27. Similarly to some other CIS countries, a significant part of the government's fiscal operations are not captured in the budget. A key component of such operations are the quasifiscal activities of the banking system and (until the year 2000) the NBB, providing subsidized credit to priority sectors, notably to agriculture and construction. Loans to agriculture are frequently at a notional interest rate of 2 percent, while the construction sector has access to financing at 50 percent or less of the refinancing rate. These quasi-fiscal activities amounted to about 3.3 percent of GDP in 1999, raising the overall fiscal deficit (including these operations) to 5.5 percent of GDP (Figure II.3). In early 2000, the Belarusian authorities improved the transparency of these operations, by including on budget the amount related to directed credits of the NBB to selected sectors. Nevertheless, commercial banks continue to be instructed to provide subsidized credit to priority sectors. It is estimated that during the first five months of the year, quasi-fiscal operations amounted to 1.4 percent of GDP, bringing, the overall fiscal deficit for the same period to 3.8 percent of GDP.

\footnotetext{
${ }^{7}$ The 2000 budget considered an end-of-period exchange rate of Rbl 575 per $\$$ while by midyear the rate was already at $\mathrm{Rbl} 675$ per $\$$.
} 
Figure Il.3. Belarus: Fiscal Operations (In percent of GDP)

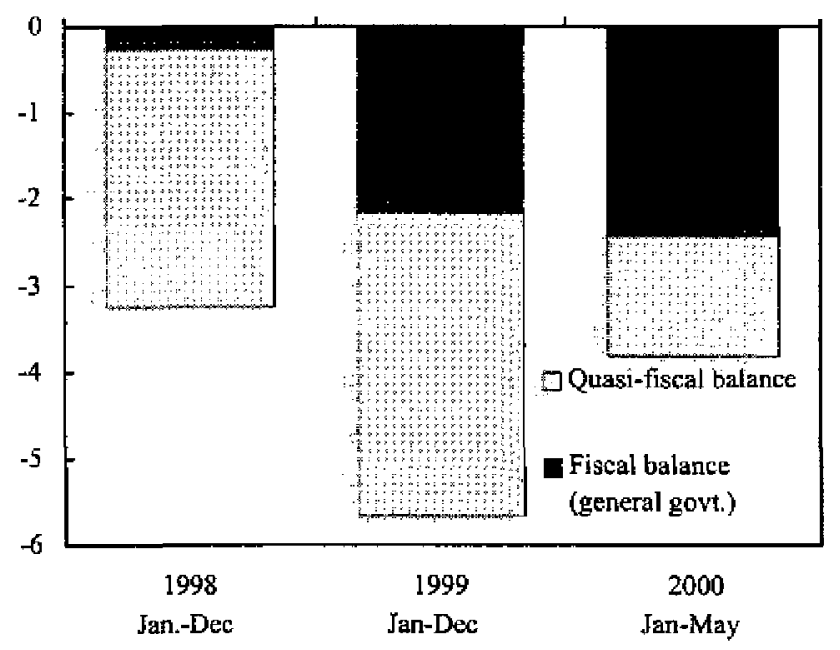

\section{Treasury system}

28. In order to improve the planning and execution of fiscal policies, the Belarusian authorities have introduced a new Treasury system. ${ }^{8}$ The objective of the new Treasury system is to improve the collection of revenue, the financing of expenditures, the accounting of financial transactions, and the preparation of accounting reports. The new system allows the direct financing of expenditure from a unified Treasury account. While in the past cash flows were channeled from the Ministry of Finance to the respective line ministries, and from there to the spending units before they finally reached those who provided the goods and services, the new system channels the resources directly to the suppliers via local agencies of the state treasury. The new system represents a major improvement, as it will make it possible for the Ministry of Finance to (i) concentrate resources at the unified treasury account; (ii) increase the flexibility to allocate resources efficiently; (iii) make more precise projections of cash budget execution; (iv) carry out preliminary control over primary documents that prove validity of amounts requested; (v) accelerate the pace of settlements with suppliers; and (vi) provide the respective ministries and spending units with timely information about the execution of the budget.

\footnotetext{
${ }^{8}$ The establishment of a new Treasury system is based on the Government's Act no. 846 of 1993. The latest changes to the Treasury system were implemented at the beginning of 2000 .
} 


\section{Monetary Sector}

\section{Developments in 1999}

29. Since the beginning of 1996 , monetary policy had been subject to the broader policy goals of the government, providing subsidized and directed credit to selected sectors of the economy. As a result of the accommodating monetary policy, rubel reserve money and rubel broad money increased rapidly. This trend accelerated in 1999, when rubel broad money increased by 195 percent. The associated high rates of inflation exacerbated the process of dollarization of the economy, as foreign currency deposits increased by some 25 percent (see Chapter IV). Monetary expansion came on the heels of a marked increase in rubel net domestic credit from the central bank, by 220 percent (Rbi 87 billion) compared to 95 percent in 1998. As in previous years, the major source of credit expansion was NBB net rubel credit to the government, which increased by some Rbl 83 billion. Most of this credit (some $\mathrm{Rbl} 79$ billion) was to provide soft loans to the construction and housing sector.

30. Although in 1999 the NBB abstained from engaging directly in the financing of the spring sowing campaign - as had been standard practice in the previous years-it continued to support specific sectors indirectly, for example through the extension of exemptions from statutory reserve requirements to banks lending to agriculture. Whereas the statutory reserve requirement for rubel and foreign currency deposits stood at 16 percent at the beginning of 1999, the effective rate for both types of deposits was about 12 percent, falling to less than 10 percent by mid-year. A subsequently tougher stance of the NBB increased compliance somewhat, but by the end of the year the effective rate amounted to only 11.5 percent.

\section{Developments in $\mathbf{2 0 0 0}$}

31. At the beginning of 2000 , the NBB began tightening monetary policy somewhat. While the NBB continued to provide direct credit to the government, it was expected to be limited to the amount stipulated in its Monetary Guidelines and Credit Policies (Rbl 76 billion), increasing the transparency of NBB operations. Although the NBB was able to keep the allocation of gross credit to the government within the limits established in the Guidelines during the first six months of 2000 (1/12 of the total amount per month), net credit to government grew by almost 58 percent during the same period, due to the drawdown in government deposits. In order to offset the higher-than-programmed injection of rubel reserve money, the NBB initially mopped up liquidity through the mobilization of deposits from commercial banks and the issuance of short-term securities. Because of the high costs 
of such a policy and the adverse implications for its profitability, the NBB subsequently increased the statutory reserve requirement on rubel deposits from 16 percent to 17 percent in February, and to 19 percent in April. ${ }^{9}$

32. While rubel broad money growth was somewhat constrained earlier in the year, it started to accelerate from March onward, reaching 15.5 percent in June. In the first half of the year, rubel broad money grew on average by 7.6 percent per month. This was far in excess of the NBB's target of 4 percent monthly growth for the year, although lower than during the same period in 1999. The monetary expansion in June was largely driven by a government's directive instructing banks to provide a total of $\mathrm{Rb} 35$ billion in credit to the agricultural sector to finance the harvest. Given the tight liquidity position of the banking system, banks were forced to sell foreign exchange to the NBB in exchange for rubel liquidify to fulfill the directive. This "forced" demand for rubels by the banking system contributed to the relative stability in the parallel foreign exchange market despite the acceleration in money growth.

33. While the NBB regained formal independence on June $1,2000,{ }^{10}$ the government has continued to influence monetary policy through its practice of instructing public and private banks to make loans to selected sectors of the economy irrespective of their ability to repay. In order to accommodate the latest directives of the government, the NBB revised upward both its annual target for net reserves accumulation and for average monthly growth of rubel broad money in 2000 (the latter from 4 percent to 6.5 percent).

\section{Interest rate policy}

34. In order to return to positive real interest rates, the NBB increased its basic refinance rate from 120 percent at the end of 1999 to 175 percent in February 2000. However, in view of declining monthly inflation rates, the refinance rate was lowered to 90 percent in June. Lombard rates have remained high compared to the refinance rate, amounting to 160 percent for 14 days funds in June (Figure II.4). The return to positive real interest rates has boosted deposit mobilization. In addition, the spread between real deposit and lending rates has widened again, reversing the trend of a compressed interest rate structure. The role of credit allocation via interest rates in Belarus is, however, still limited since certain banks continue to have access to resources at lower cost, for example, through waivers from statutory reserve requirements.

\footnotetext{
${ }^{9}$ The statutory reserve requirement for foreign deposits remained unchanged at 16 percent (see Chapter IV).
}

${ }^{10}$ A presidendial decree cancelled a former decree that subordinated the NBB to the government. 
Figure I1.4. Belarus: Interest Rates, January 1996-June 2000

(In percent per annum)

Nominal Refinance Rate

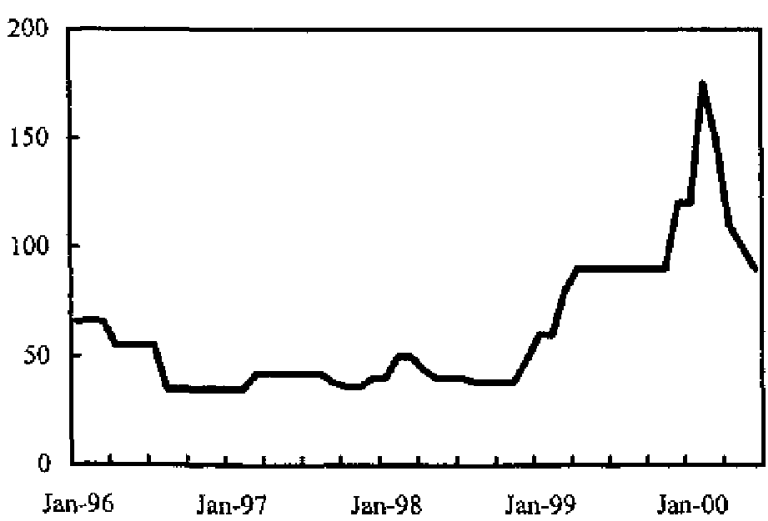

Basic Lombard Rate

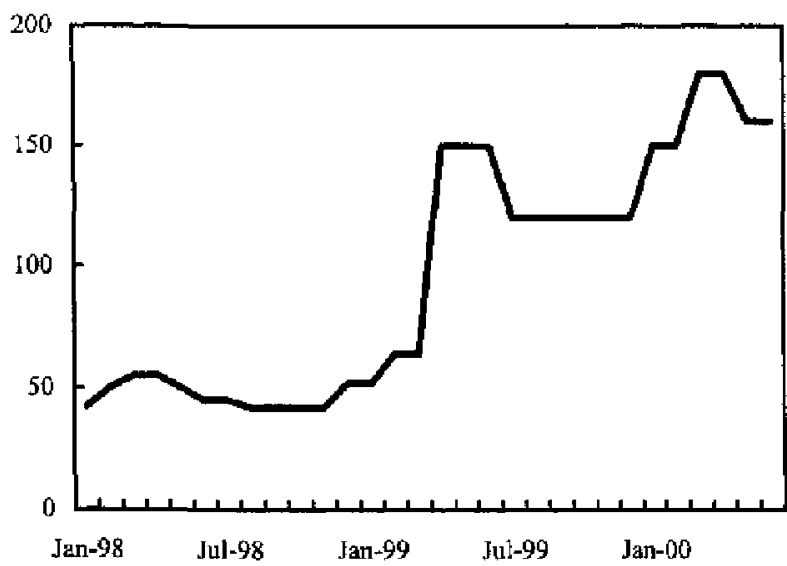

Nominal Lending and Deposit Rates

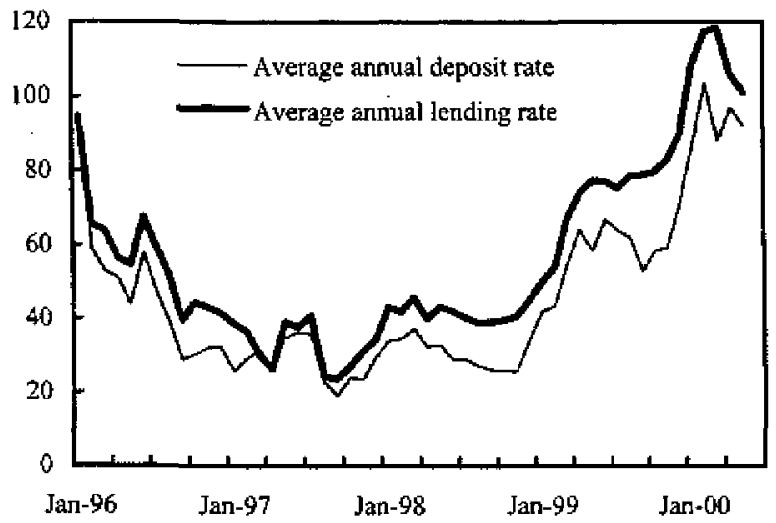

Real Refinance Rate 1/

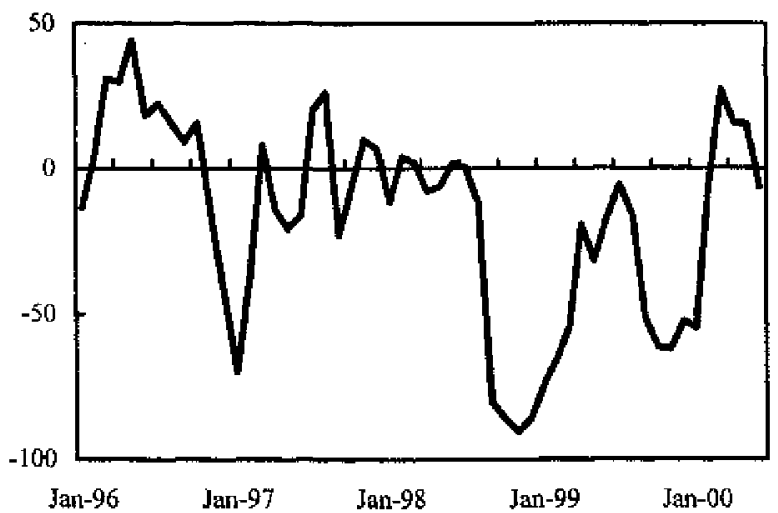

Real Lombard Rate 1/

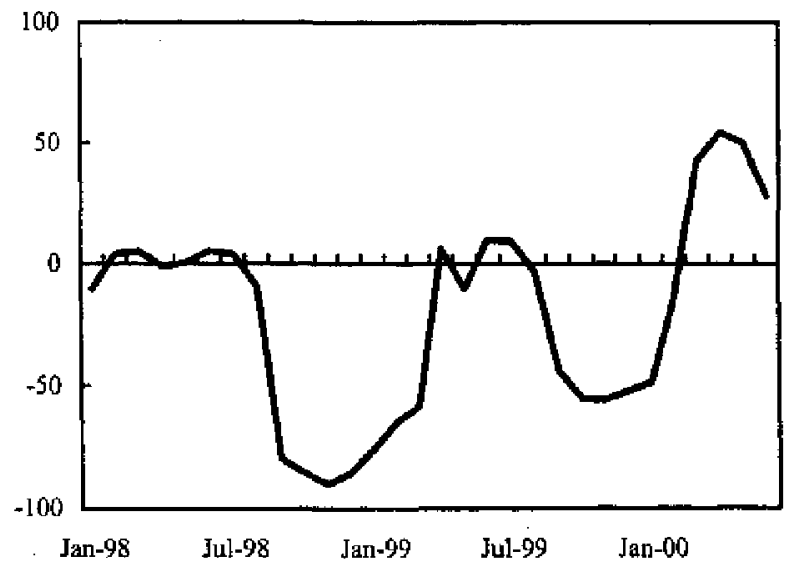

Source: National Bank of Belarus; and Fund staff estimates.

1/ Deflated at the contemporaneous inflation rate. 
35. Primary market yields for government securities have closely mirrored the basic refinance rate. Since banks are the prime buyers of government securities, their continued mandate to provide directed credit to specific sectors in the context of tighter liquidity conditions have reduced their demand for government securities. This comes despite the fact that banks are allowed to engage in repurchase operations with the NBB at their own discretion-within specified limits-to increase their liquidity, and therefore have an incentive to purchase government securities. Unlike in 1999, the NBB abstained from buying government securities in the primary market during the first half of 2000 .

\section{Developments in 1999}

\section{External Sector}

\section{Current account}

36. Foreign trade and services contracted sharply following the Russian crisis and did not recover for the most part of 1999. A slowdown in domestic demand and the 1998/99 payments crisis in Russia led exports and imports to decline by 17 and 23 percent, respectively, year-on-year in dollar terms. As a result, the trade deficit was cut in half, reaching $\$ 599$ million (5.2 percent of GDP). The current account deficit fell by more than two-thirds, reaching $\$ 257$ million (2.2 percent of GDP). ${ }^{11}$

37. The competitiveness of Belarusian exports remained affected by the multiple exchange rate system, as well as by real exchange rate volatility in the wake of the Russian crisis (see Figure II.5). The 30 percent export surrender requirement - with export revenues being exchanged at the overvalued official exchange rate-was equivalent to an implicit export tax that oscillated between 15 and 20 percent during 1999, depending on the spread between the official and the parallel market rate. ${ }^{12}$ The annual average real exchange rate depreciated by over 30 percent against the dollar on both official and parallel markets, but appreciated slightly against the Russian ruble. These exchange rate movements, coupled with the payments crisis in Russia, supported a reorientation of Belarusian exports toward nonCIS countries. While exports to the CIS fell by 29 percent in dollar terms in 1999, exports to the rest of the world rose by 20 percent. Nevertheless, Russia remained Belarus' largest trading partner, with an export share of 55 percent and an import share of 56 percent (Figure II.6).

\footnotetext{
1) The trade and current account deficits amounted to respectively 12.1 and 5.2 percent of GDP evaluated at the parallel market rate.

${ }^{12}$ The implicit export tax is calculated as the percentage loss in export revenue arising from the spread of the parallel over the official exchange rate, multiplied by the 30 percent surrender requirement.
} 
Figure II.5. Belarus: Real Exchange Rates

Real Official Rates, January 1997-June 2000

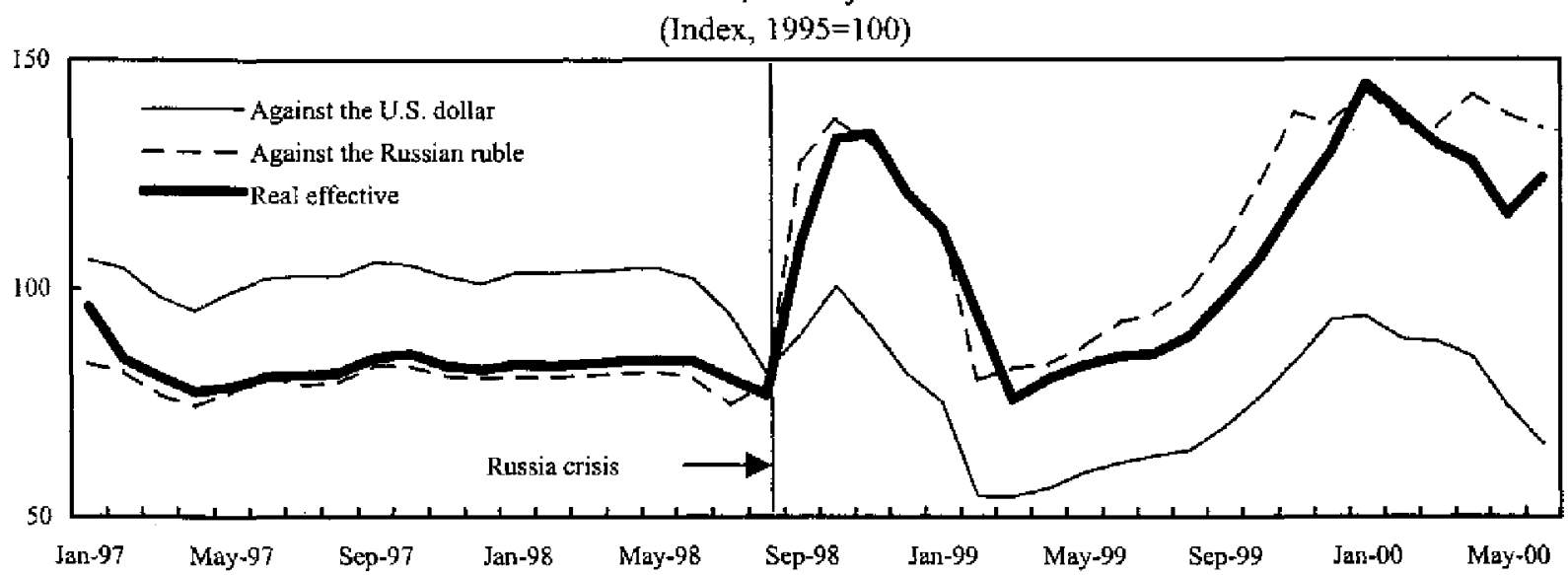

Real Parallel Rates, January 1997-June $20001 /$

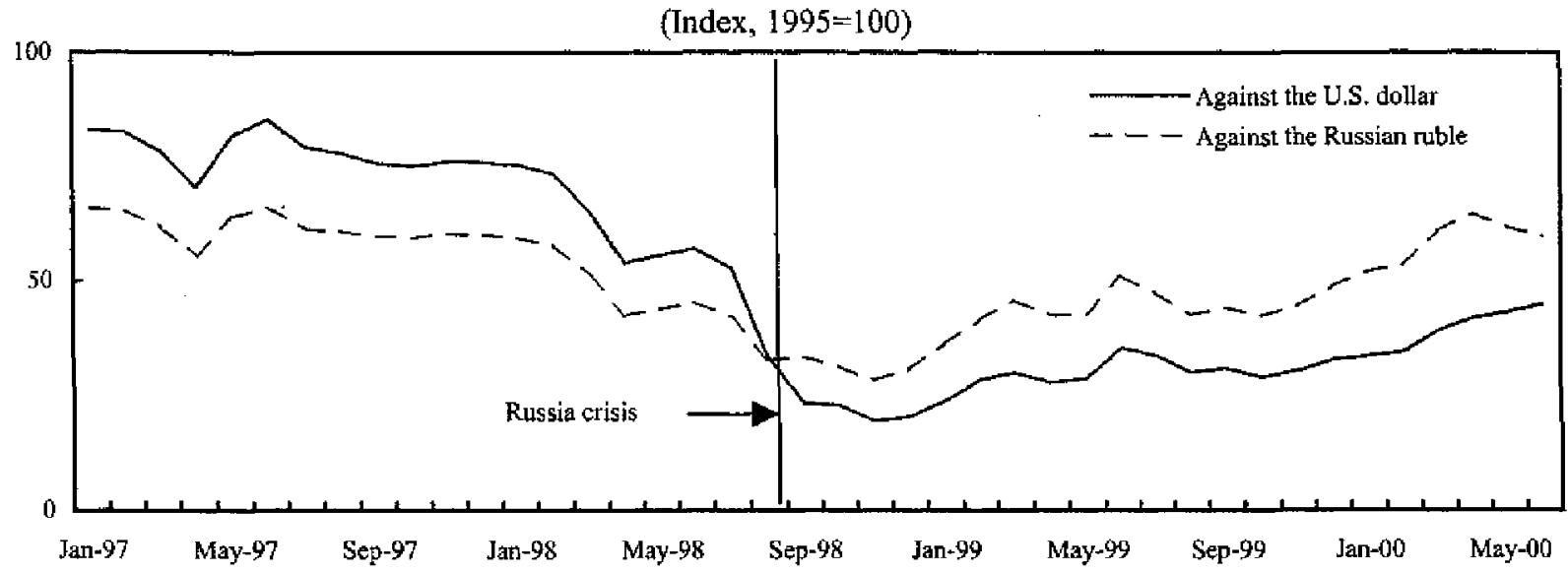

Exchange Rate Spreads Between Official and Parallel Rates, January, 1998-June 2000

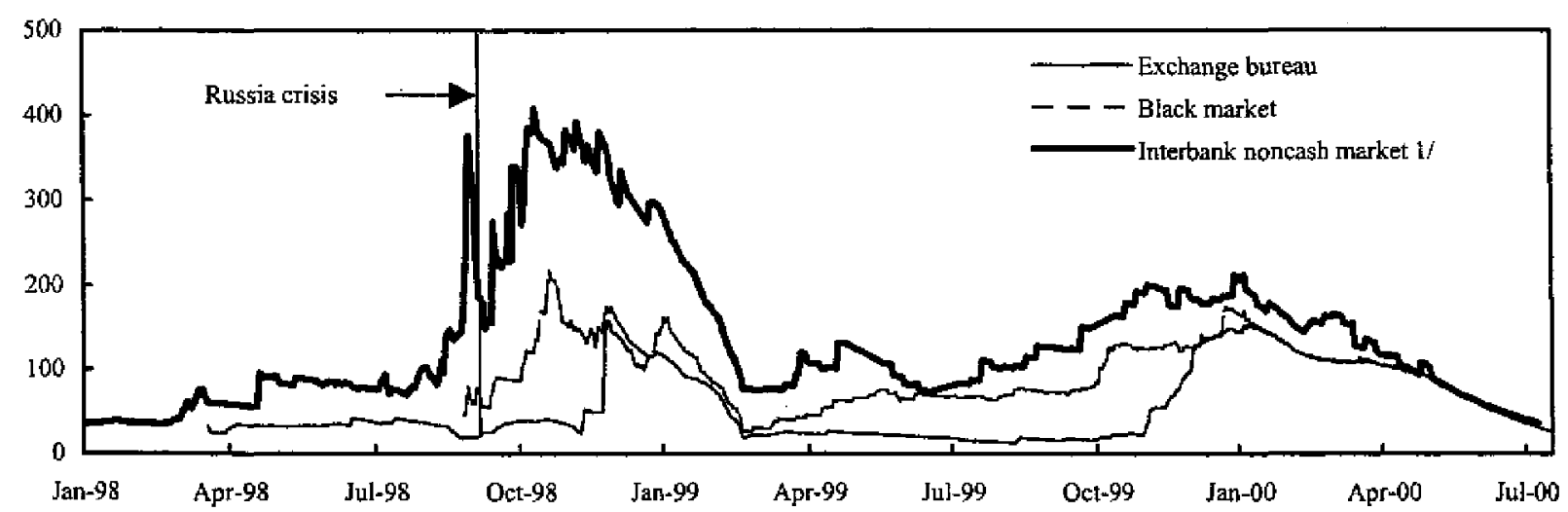

Source: Belarusian authorities; and Fund staff estimates.

1/ The "parallel market rate" used here is the interbank noncash market rate. Until October 1998, this rate was based on the Moscow interbank market rate. 
Figure II.6. Belarus: Share of CIS Countries and of Russia in Total Trade, 1993-99

(In percent)

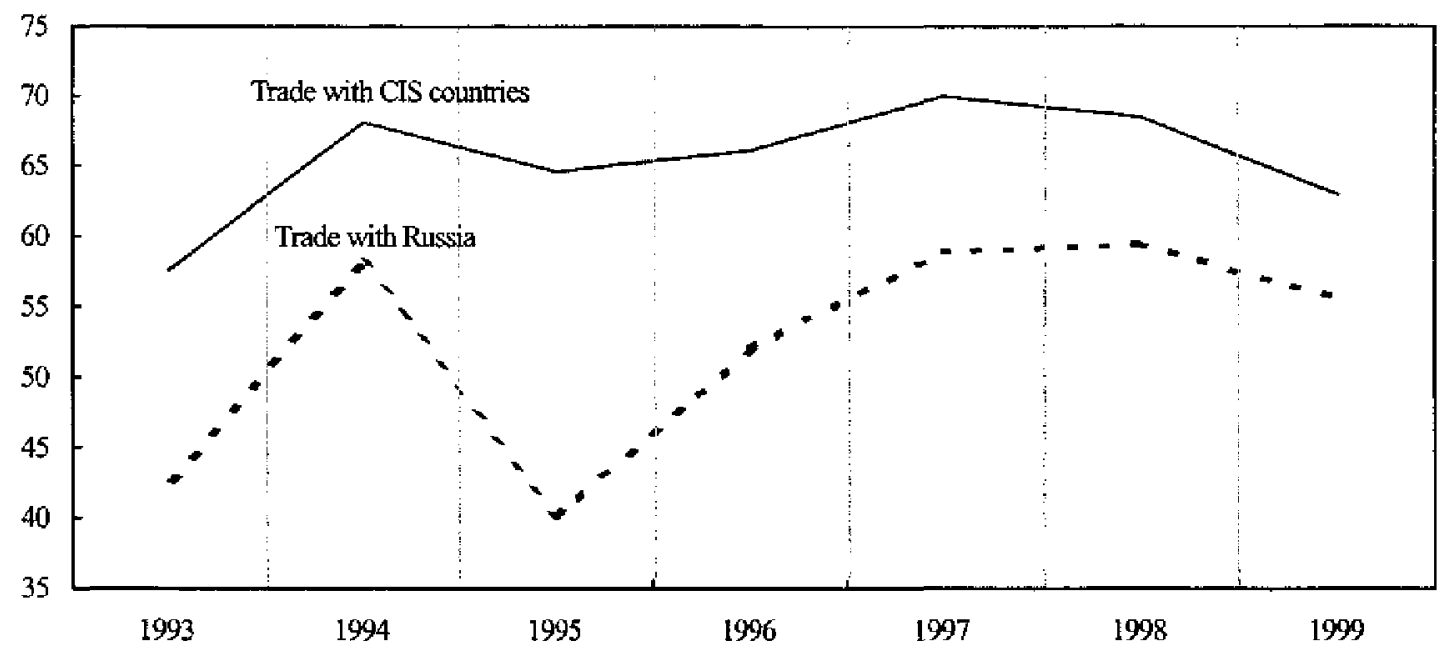

Source: Belarusian authorities; and Fund staff estimates.

38. Belarus forms a customs union with Russia, Kazakhstan, the Kyrgyz Republic, and Tajikistan, although numerous restrictions remain in place. The authorities are working toward further harmonization of trade policies with Russia (see Chapter V). Although the two trade regimes are very similar, there are still inconsistencies, including price restrictions on exports of goods subject to domestic price control (mainly meat, dairy and leather) from the Belarusian side, as well as a recent measure by Russia (in March) to impose tariffs on imports from third countries on transit through Belanus, followed by a similar measure by Belarus (in August).

\section{External financing and debt}

39. External financing remained scarce in 1999. Net inflows in the capital account, mainly reflecting transfers from migrants, fell by more than half, to $\$ 60$ million. Net portfolio inflows were negative and net inflows of medium- and long-term credit were close to zero. Foreign direct investment, however, increased from \$147 million to \$224 million, mainly due to additional financing by Russia's Gazprom of the Yamal gas pipeline project. The improvement in the current account allowed an increase in the central bank's net convertible foreign assets of $\$ 30$ million. However, gross reserves remained very low at $\$ 309$ million, equivalent to about two weeks of imports.

40. While debt and debt service ratios are modest by CIS standards, Belarus is exposed to a high share of short-term debt and arrears. The total stock of foreign debt fell by about $\$ 100$ million during 1999 to $\$ 2.3$ billion at the end of the year (20 percent of GDP evaluated 
at the official exchange rate or 46 percent of GDP evaluated at the parallel market rate), of which $\$ 1.3$ billion were short-term credits and arrears. Over 50 percent of medium- and longterm external liabilities are loans to the Belarusian government, while another 40 percent are sovereign-guaranteed loans to domestic banks and enterprises. Debt service on public and guaranteed debt (including the IMF) grew from $\$ 146$ million in 1998 (of which $\$ 90$ million in amortization) to $\$ 210$ million in 1999 (of which $\$ 159$ million in amortization), which amounted to 3.1 percent of exports of goods and services. ${ }^{13}$

41. External arrears were brought down by $\$ 61$ million in 1999 , after the state-owned gas and electricity monopolies, Beltransgaz and Belenergo, reduced their overdue payables on imported energy by $\$ 41$ million. This brought the total amount of gas arrears (mostly owed to Russia) to \$234 million and electricity arrears (mostly owed to Russia and Lithuania) to $\$ 96$ million. Virtually all payments for energy imports are made in barter, and arrears are usually settled through offsets with industrial goods. Other arrears grew in 1999, including arrears on sovereign guaranteed debt, which rose from $\$ 15$ million to $\$ 36$ million.

\section{Developments in 2000}

42. The contraction of foreign trade was sharply reversed in late 1999 and trade grew rapidly in early 2000 . During the first five months, exports rose by 25 percent in dollar terms year-on-year, on the heels of the recovery in Russia and following measures in Belarus to liberalize the foreign exchange markets (see Appendix I). Imports rose by an even higher 36 percent, again partly due to foreign exchange liberalization, but also due to higher oil prices. As a result, the trade deficit widened to $\$ 524$, compared to $\$ 205$ million in the first five months of 1999. The negative trade impact on the current account balance was partly offset by an increase in transport revenues. Barter trade made up 28 percent of exports and 22 percent of imports during the first five months of 2000 , down from 38 and 34 percent in the same period in 1999. The fall is partly due to the introduction of a 15 percent fee on international barter transactions in 1998 (this measure was suspended in August 2000). About a quarter of all barter transactions are imports of natural gas from Russia in exchange for industrial products from Belarus.

43. The overall balance of payments position deteriorated in early 2000 as the increase in the current account deficit was not matched by additional inflows of foreign capital. The financial account showed a deficit of $\$ 116$ million in the first quarter of 2000 , reflecting a drop in FDI related to the Yamal gas pipeline project and continued scarcity of loan financing. This led to an accumulation of $\$ 77$ million in payments arrears during the first quarter, mostly reflecting renewed growth in energy arrears to Russia, but also a \$6 million increase in arrears on sovereign-guaranteed debt. Despite the weak external position, net official reserves rose by about $\$ 45$ million during the first half of 2000 , as a result of purchases by the central bank.

${ }^{13}$ Repayments to the IMF amounted to $\$ 58$ million in 1999 , up from $\$ 24$ million in 1998 . 


\section{Exchange rate developments}

44. Belarus' multiple exchange rates were subjected to large swings in the wake of the Russian crisis. The spread between the official and the parallel rate rose from 78 percent in mid- 1998 to almost 300 percent at the beginning of 1999 , then falling back to 74 percent in mid-1999, before rising again to 184 percent at the end of the year.

45. A number of liberalizing measures in late 1999 and early 2000 brought about important changes in the exchange rate system. The four main parallel markets-the cash market in exchange bureaus, the additional session in the Belarus Currency and Stock Exchange (BCSE), the non-cash interbank market, and the offshore market in Russia and the Baltics - were freed of most restrictions. However, by mid-2000 exporters were still required to surrender 30 percent of their export proceeds at the main session of the BCSE, using the overvalued official exchange rate. ${ }^{14}$

46. The NBB's Monetary Guidelines for 2000 stipulate further exchange liberalization and exchange rate unification during the year. In the first half of the year, the NBB pursued this goal by depreciating the official rate more rapidly. By July 31 , the official rate stood at Blr 790 to the dollar, while exchange bureaus were trading dollars for Blr 980 , a spread of 24 percent, compared to 184 percent at the beginning of the year. Moreover, the four parallel exchange rates converged to within less than five percent of each other. They remained relatively stable in nominal terms and appreciated in real terms during the first half of 2000 , reflecting tighter monetary policy, the accelerated depreciation of the official rate, and the shift from the black market to the exchange bureaus in the wake of liberalization.

\section{E. Structural Policies}

47. There have been no major strides in advancing structural reform. The state continues to control or intervene in most aspects of the economy, either directly or indirectly, through public ownership, the legal and regulatory framework, administrative restrictions, price and wage controls, foreign trade and exchange restrictions, and monetary and credit policies. The overall business environment continues to be marred by an unstable legal and regulatory framework, which remains one of the most important structural problems in Belarus (see Chapter VI).

48. There has been no progress in price liberalization; extensive price controls continue to affect all enterprises in Belarus. The government regulates prices of 26 "strategic enterprises", such as the domestic suppliers of fertilizer, glass, and cement. Also, the prices for "socially important goods" continue to be fixed. They include five categories, one each

${ }^{14}$ The main session was merged with the afternoon session in mid-September 2000 . The NBB announced that from then on, the official rate would be determined by supply and demand during the merged session. 
for bread and a number of dairy products, two categories for meat products, and finally vodka. In addition, ceilings on monthly price increases are imposed on all enterprises and therefore apply to all other products.

49. Housing and communal services continue to be heavily regulated. Although rents were adjusted upwards by 11 percent in July 2000 and utility rates rose by $11-40$ percent at the same time, households still cover significantly less than 25 percent of the costs of housing and communal services. The monthly rent for a 100 -square meter apartment, for example, stood at less than 50 cents during July 2000 (measured at the parallel exchange rate). Gas cost 7 cents per tenant per month during the same period. More generally, cost recovery rates vary from 13 percent for communal services (including housing, electricity, and heating) to an average of 20 percent for all regulated goods and enterprises.

50. Little has been achieved on privatization. The Belarusian government still runs a long list of 960 enterprises that are not to be privatized on account of national interest. Also, no efforts have been made to pursue small and medium-size or communal enterprise privatization. In this area, decisions are at the discretion of very reluctant local authorities. Hence, after almost a decade of transition, even small-scale privatization is only half completed. About 50 percent of vouchers issued to the public have been used so far.

51. Large-scale enterprise privatization has not progressed significantly. Most companies, including joint stock companies, remain majority state-owned. This is partly the result of substantive involvement of workers collectives in the privatization process. Nonetheless, the privatization plan for 2000 includes the transfer of some 170 republican and 300 communal enterprises into private hands. It also includes the transformation of 50 state enterprises into joint-stock companies following the recent revaluation of the outstanding stock of vouchers to $\mathrm{Rbl} 1,200$ each. Although a new bankruptcy law was adopted in July 2000 , there are major uncertainties with respect to its implementation. Finally, the golden share rule, granting the government possible interference in privatized companies' decisions, is still effective for financial institutions.

52. On the positive side, a targeted social safety net was adopted by the government on May 29, 2000, with technical assistance from the World Bank. It is expected to become operational on January 1,2001 and could support full-scale price liberalization. Current estimates suggest that about 700,000 people would be eligible to benefits, on the basis of income declaration (see Chapter VII). 


\section{AN ASSESSMENT OF BANKING SECTOR VulNERABILITIES ${ }^{15}$}

\section{A. Background}

53. Belarus converted to a two-tier banking system during 1991. The former Belarus branch of Gosbank (the Soviet Union's state bank) was transformed into a central bank, the National Bank of Belarus (NBB), while branches of the former USSR specialized banksSavings Bank, Agroprombank, Promstroibank and Vnesheconombank-were converted into specialized commercial banks. In 1996 the Savings Bank was merged with the private Belarus Bank, thereby becoming the largest bank in the system, holding more than 50 percent of housebold deposits. Belagroprombank and Belarusbank jointly account for over 51 percent of all banking sector assets.

54. The NBB refers to the former Soviet banks and two newer "universal" banks-Priorbank and Belbusinessbank-as the six "system-forming" banks. " These banks collectively account for 85 percent of total banking system assets, 87 percent of enterprise lending and over 90 percent of lending to households and household deposits (Table III.1). The state directly owns a majority share in three of these banks and a significant minority share (a minimum of 35 percent in the case of Priorbank) in the others. ${ }^{17}$ The NBB itself continues to maintain a direct shareholding in several of them. Senior government officials effectively control the decision-making of the ex-Soviet specialized banks, and there is a high degree of state control in respect of their lending and credit allocation decisions. ${ }^{18}$ These banks are generally considered to be non-profit enterprises with social obligations to contribute to the development of the economy, including by their senior management.

55. The rest of the banking system is highly fragmented, comprising twenty two locallyowned banks and some joint ventures. A number of the former would appear to be "pocket" banks of state-owned enterprises. For example, Belgazprombank is the subsidiary of the state-owned gas monopoly. Despite the joint-ventures, the only significant foreign presence is a branch of the Russian Mossbusinessbank. Nine banks were in administration

\footnotetext{
${ }^{15}$ Prepared by Michael Taylor.

${ }^{16}$ Referred to in this chapter as the "core" banks.

${ }^{17}$ In practice the extent of indirect state ownership may be much higher, as most other bank shareholders are state-owned enterprises (SOEs). The EBRD has a 27 percent shareholding in Priorbank.

${ }^{18}$ Currently, the Finance Minister is the Chairman of the Supervisory Board of Belarusbank, and a Deputy Prime Minister is the Chairman of the Supervisory Board of Belagroprombank.
} 
Table III.1. Belarus: Banks' Assets, May 2000

(In millions of rubels; unless otherwise indicated)

\begin{tabular}{|c|c|c|c|c|c|}
\hline & $\begin{array}{l}\text { Banks that received } \\
\text { capital support }\end{array}$ & $\begin{array}{l}\text { Other "core" } \\
\text { banks }\end{array}$ & $\begin{array}{l}\text { Total "core" } \\
\text { banks }\end{array}$ & $\begin{array}{r}\text { Total all remaining } \\
\text { banks }\end{array}$ & $\begin{array}{r}\text { Total batking } \\
\text { system }\end{array}$ \\
\hline Total assets & 636,406 & 384,010 & $1,020,415$ & 182,891 & $1,203,306$ \\
\hline $\begin{array}{l}\text { Cash and balances with NBB } \\
\text { of which: }\end{array}$ & 22,040 & 33,854 & 55,894 & 15,329 & 71,223 \\
\hline Mandatory reserves & 17,109 & 26,368 & 43,478 & 12,707 & 56,185 \\
\hline Trading securities (at market value) & 12,020 & 32,087 & 44,107 & 36,383 & 80,490 \\
\hline Loans to banks and other credit institutions (net of provisions) & 7,926 & 26,133 & 34,059 & 40,208 & 74,267 \\
\hline Loans and advances to central government & 11,636 & 14,660 & 26,296 & 13,004 & 39,300 \\
\hline $\begin{array}{l}\text { Loans and advances to enterprises (net of provisions) } \\
\text { of which: }\end{array}$ & 224,128 & 233,181 & 457,309 & 62,077 & 519,386 \\
\hline Loans and advances to state enterprises & 94,151 & 103,294 & 197,445 & 27,679 & 225,124 \\
\hline Loans and advances in foreign currency (in millions of U.S. dollars) & 122 & 244 & 365 & 71 & 436 \\
\hline Loans and advances to households & 496 & 868 & 1,364 & 374 & 1,738 \\
\hline $\begin{array}{l}\text { Investment securities } \\
\text { of which: }\end{array}$ & 188 & 2,858 & 3,046 & 374 & 3,420 \\
\hline Equity investment in financial intermediaries & & & & 7 & 7 \\
\hline Equity investment in nonfinancial intermediaries & 188 & 2,858 & 3,046 & 367 & 3,413 \\
\hline Fixed assets (net of depreciation) & 32,537 & 40,369 & 72,905 & 15,142 & 88,047 \\
\hline \multicolumn{6}{|l|}{ Memorandum items: } \\
\hline NBB credit & 12,391 & 737 & 13,128 & 1,615 & 14,742 \\
\hline Equity capital & $68,73 \mathrm{I}$ & 39,740 & 108,471 & 45,308 & 153,780 \\
\hline Equity/Assets ratio & 20 & 10 & 30 & 25 & 13 \\
\hline Total assets (valued at market rate) & 735,388 & 482,668 & $1,218,055$ & 211,646 & $1,429,701$ \\
\hline Adjusted equity/assets ratio $\mathrm{I}$ & 17 & 8 & 26 & 21 & 29 \\
\hline
\end{tabular}

Source: National Bank of Belarus; and Fund staff estimates.

1/ The adjusted equity figure is shown net of additional provisions assessed by the NBB. 
(conservatorship) as of January 2000 , with the total number of banks having been reduced from 53 in 1995 to 28 as of mid-2000. ${ }^{19}$

56. Notwithstanding recently improved mobilization of deposits, especially during 2000, banking sector assets amount to approximately 15 percent of estimated 2000 GDP, among the lowest of the CIS countries. Even this figure may not be entirely accurate since, although banks were required in theory to be audited to International Accounting Standards (IAS) from 1996, there are still some significant gaps in their compliance. Most notably, there would appear to be a lack of compliance with IAS 29, financial reporting in hyperinflationary economies, which potentially could give rise to an overstatement of the banking sector's assets and liabilities, thus inflating the size of the banking sector relative to GDP.

\section{B. Assessment of Vulnerabilities ${ }^{20}$}

57. The high degree of state control and ownership of the banking system reduces its vulnerability in the short-term as long as the government has the fiscal and monetary resources to stand behind the core banks. But this relative insulation from short-term vulnerabilities is achieved at the expense of the banking system's long-run viability and efficiency, and also requires periodic resort to monetary financing or fiscal injections to repair damage to banks' balance sheets. Without thorough-going structural reform the need for such interventions will continue.

58. In recent years some progress has been made by the authorities in improving the capitalization of the banking sector and in provisioning for nonperforming assets. In the first half of this year, banking system capital increased by almost 12 percent in real terms; banks' capital grew by 72 percent in nominal terms and, as of July 1, 2000, amounted to Rbl 227.4 billion. In 1999 the two main former specialized banks, Belagroprombank and Belarusbank were recapitalized, to the amount of $\mathrm{Rbl} 42$ and $\mathrm{Rbl} 43$ respectively (approximately 2.4 percent of GDP). This has raised their capital ratios to well above the 10 percent minimum required by the NBB.

59. However, although equity in the banking system has increased in real terms, lending by the banks increased more rapidly during the same period. Between January and June 2000 , the assets of banks almost doubled and, as of July 1, 2000, amounted to Rbl 1,535 billion (approximately $\$ 1.6$ billion, valued at the parallel exchange rate), of which assets in local currency accounted for 43 percent, or Rbl 656 billion.

${ }^{19}$ A comparison of a list of banks in administration as of January 2000 with a list for the same month the previous year indicates that the liquidation of only one bank was completed during that time.

${ }^{20}$ It should be noted that, due to confidentiality concerns, the data were not as comprehensive as would have been desirable for a full in-depth study of the banking system. 
60. Despite the improved capitalization of the major banks and the NBB's adoption of a risk-based capital adequacy framework (see below), several potentially very serious sources of vulnerability remain unaddressed. In the first place, the primary borrowers from the banking system continue to be state-owned enterprises, many of which are likely to be in need of extensive restructuring. As Table III.1 demonstrates, loans and advances to state enterprises represent 47 percent of total lending to enterprises, and the true figure may be much higher given the way that the state-owned sector is classified in Belarus. ${ }^{21}$ The extent to which such credit may ultimately be recoverable is at the present time difficult to ascertain, but it is likely that large unrealized credit losses currently exist within the banking system.

61. Secondly, several of the core banks-most notably Belagroprombank and Belarusbank-as a matter of policy extend loans to certain priority sectors at subsidized rates. For example, Belarusbank extends housing improvement loans at 20 percent annual interest (recently increased from 5 percent annual interest) compared with a refinance rate of 90 percent, and a cost of funds (including unremunerated reserve requirements) of approximately 155 percent. $^{22}$ The pressure on these banks to extend subsidized credit is increased by a series of ad hoc government and presidential interventions.

62. The cost of providing subsidized credit has to be borne by the government either directly on the state budget or indirectly by accepting a reduced return on its investment in the state-owned banks. The latter seems to be the preferred approach, with the result that losses on subsidized lending are recognized in banks' income statements. However, if these losses are sufficiently large, they will ultimately result in a reduction in shareholders' funds, or additional burden for the budget. In a sense, therefore, it is possible to view the recent recapitalization of two of the state banks as being merely a prepayment of a subsidy for future loss-making lending. As long as the banks continue to engage in these loss-making activities, the value of their equity will be eroded over time, thus making additional recapitalizations inevitable in the future. ${ }^{23}$

63. Other ad hoc government interventions, intended to secure foreign exchange for the purchase of imported grain and to provide credit to the agricultural sector, have weakened the banking sector still further. In October 1999, leading banks were required to make loans

${ }^{21}$ For example, subsidiaries of SOEs do not appear to be classified as SOEs.

${ }^{22}$ Calculated on the basis of a deposit interest rate of 130 percent and a 16 percent reserve requirement, but excluding the need to cover operating expenses.

${ }^{23}$ The recapitalization of Belarusbank and Belagroprombank in 1999 took place less than two years after the previous one. In the most recent instance the recapitalization took the form of the conversion of government deposits into equity, whereas previously the recapitalization was accomplished through the provision of NBB credit. 
totaling $\$ 25$ million for the import of grain by the government; in June 2000 , these banks were required to provide a further $\$ 31$ million payable over three months for on-lending to the agriculture sector. This involved them swapping their foreign exchange assets for rubeldenominated assets with a doubtful repayment capacity, while at the same time increasing their exposure to liquidity and foreign exchange risk. These ad hoc interventions in support of agriculture may explain why this was one of the few economic sectors to have experienced a real terms increase in credit between 1998 and 1999 against the background of a real terms overall decline in bank credit (Table III.2).

Table III.2. Belarus: Commercial Bank Loans by Economic Sector, 1995-99 (In billions of rubels; end of period)

\begin{tabular}{|c|c|c|c|c|c|c|}
\hline & 1995 & 1996 & 1997 & 1998 & 1999 & $\begin{array}{r}1999 \\
\text { (in constant } \\
1998 \text { rubels) }\end{array}$ \\
\hline Total lending & 8.8 & 21.5 & 48.5 & 193.6 & 442.7 & 176.9 \\
\hline Agriculture & 0.6 & 1.5 & 3.4 & 11.7 & 51.0 & 20.4 \\
\hline Industry & 1.9 & 9.4 & 21.4 & 90.4 & 168.3 & 67.2 \\
\hline Construction & 0.2 & 1.2 & 1.8 & 3.9 & 1.4 & 0.6 \\
\hline Trade & 1.1 & 2.7 & 5.1 & 25.2 & 69.1 & 27.6 \\
\hline Housing and communal services & 0.1 & 0.1 & 0.1 & 0.6 & 1.3 & 0.5 \\
\hline Households & 0.3 & 1.5 & 8.9 & 25.0 & 73.0 & 29.2 \\
\hline Other & 4.6 & 5.1 & 7.7 & 36.9 & 78.7 & 31.4 \\
\hline
\end{tabular}

Source: National Bank of Belarus; and Fund staff estimates.

64. Although an unspecified proportion of banking system assets, including some of those denominated in foreign currency, are subject to governmental guarantee, the extent of these guarantees may paradoxically represent a further source of vulnerability. Lending under government guarantee has reportedly become the rule rather the exception in providing credit to the agriculture sector and, perhaps, other sectors as well. However, the extent of these guarantees may mean that the government will have difficulty in meeting its obligations should it ever be called on to do so. Where govermment guarantees have been offered on foreign currency denominated loans, the government's ability to obtain access to sufficient foreign exchange to honor its guarantees may be limited. ${ }^{24}$ Moreover, the existence of

${ }^{24}$ In conversation a number of bankers admitted that they were unlikely to attempt to call the guarantee in the event of borrower default; some suggested that foreign currency guaranteed lending was likely only ever to be repaid in rubel, if at all. 
extensive guarantees clearly represents a contingent liability on the government budget, which could have serious macroeconomic implications if it were ever to be crystallized. Since banks are unable to provision for lending that carries a government guarantee, their potential future losses could be significantly understated if ultimately it is beyond the capacity of the government to honor all the guarantees it has granted.

65. The NBB estimates that problem loans (substandard, doubtful and loss) currently amount to Rbl 110 billion, or 17 percent of all loans and 48 percent of banking system equity. Even assuming that this recognizes all banks' potential future losses-something that is doubtful given the factors mentioned above-current levels of provisioning are inadequate. Although the NBB requires 100 percent provisioning against loans classified as "loss", this classification is applied only to lending from which there is no prospect of any further recovery (i.e. the entity to which the loan was made has been liquidated). This is a much more restrictive definition than that normally applied. Moreover, even using these criteria, the NBB estimates that there is a need for an additional Rbl 11.5 billion in provisions, over and above those already made, to meet its provisioning rules. At least one major bank has been given until 2003 to make the necessary additional provisions; the strategy with regard to the rest is unclear. In addition, although the problem of nonperforming loans has been primarily concentrated in foreign currency denominated assets, loan loss provisions have been made overwhelmingly in rubel. One implication is that the depreciation of the official exchange rate, associated with exchange rate unification, will create an even larger gap between actual and required provisions.

66. Looking ahead, banking sector vulnerability appears to be increased rather than reduced by the current policy stance. Exchange rate unification is likely to have an adverse impact on banks' financial condition on several counts. The problem of foreign currency loans being provisioned in rubel has already been mentioned. In addition, bank capital denominated in rubel will also decline relative to assets, as foreign-currency-denominated assets are revalued as a result of the unification. ${ }^{25}$ Thirdly, rubel depreciation will also cause further breaches of supervisory requirements, including limits on large credit exposures. Finally, depreciation of the official rate associated with unification will impose further losses on the banks. The staff has not been in a position to form a precise estimate of the magnitude of this effect, but based on information provided by the NBB it would appear that the dollardenominated deposits exceed banks' dollar-denominated lending by a significant margin.

67. The greatest challenge to banking system stability is, however, represented by the tighter monetary policy necessary to underpin exchange rate unification. Indeed, it is unclear whether the banking system will remain viable in the absence of readily available central bank credit given the problems of solvency and liquidity resulting from lending to unrestructured state enterprises. The level of rubel-denominated nonperforming loans can in

${ }^{25}$ Table III.1 estimates the extent of this effect, as a reduction in the equity/assets ratios in the order of $2-3$ percentage points. 
any case be expected to increase. To date, high levels of inflation have eased the repayment burden on borrowers in rubel, and hence the problem of nonperforming loans has been concentrated in foreign-currency-denominated lending. However, maintaining the current policy of positive real interest rates increases the burden on borrowers in rubel, thus making it more likely that the level of rubel-denominated nonperforming loans will rise significantly beyond their present levels. This will impact adversely on bank's financial soundness and current levels of capitalization may appear overstated as a result.

68. Because the problems of the banking sector are structural, most notably due to banks' quasi-fiscal responsibilities, a radical approach will be necessary to solve them. In the absence of decisive action in this area there is a significant risk that monetary tightening will result in banking system distress. To maintain consistency with the adoption of a tighter monetary policy, the costs of bank restructuring and protecting depositors will need to be met by the fiscal authorities. The extent of the likely fiscal impact cannot be established until the authorities are able to form a full and accurate picture of the financial condition of the banks. As a first step, all banks need to be audited fully in compliance with International Accounting Standards, and asset valuation rules that are more closely aligned with accepted international best practice should be adopted. In addition, banks' quasi-fiscal activities should be phased out and government involvement in, and ownership of the banking system should be reduced over time to permit market-based financial intermediation to develop.

69. Notwithstanding the absence of macroeconomic stability and market-based financial intermediation that are the normal preconditions for the introduction of deposit insurance, a scheme was introduced in Belarus in 1996. Given the continuing absence of these preconditions, it would be premature to introduce the changes to this system that are currently being contemplated by the authorities (Box 2).

\section{Regulatory Environment and Banking Supervision}

70. The NBB has taken a number of steps recently to improve its prudential supervision. Earlier in 2000 it adopted new prudential rules on risk-adjusted capital requirements that are modeled on the European Union's directives on a solvency ratio and own funds for credit institutions. ${ }^{26}$ The minimum risk-adjusted capital ratio has been set at 10 percent (the same as in Russia and several other transition economies). Of the 28 banks in Belarus, 5 did not comply with this minimum capital ratio as of 1 May 2000. Two of these banks, however, have given the NBB undertakings that they will raise additional capital and a third has been acquired by Vnesheconombank. The NBB's strategy with regard to the remaining two banks is unclear.

\footnotetext{
${ }^{26}$ These are in turn modeled on the Basel Capital Accord.
} 


\section{Box 2: Deposit Insurance}

The normal preconditions for the introduction of a successful deposit insurance scheme are macroeconomic stability and market-based financial intermediation. Notwithstanding the absence of these conditions in Belarus, a deposit guarantee system was established there in 1996. Reflecting the difficulty of establishing a credible system of limited deposit insurance where government ownership of the banks remains widespread, the 6 "system-forming" (core) banks were excluded from the scheme. Other banks pay an amount equivalent to 0.1 percent of their deposits into a reserve fund with the NBB. Although there is a target for the fund equivalent to 5 percent of the total liabilities of the insured banks, the reserve currently stands only at approximately half this amount. NBB staff estimate that this is insufficient to cover the bankruptcy of a medium-sized bank. Although the reserve fund is held at the National Bank, it is not held in a dedicated account but is commingled with other central bank reserves. The scheme is administered by a committee of NBB staff.

Both rubel and foreign currency deposits made by households (but not enterprises or small businesses) are covered. The maximum payout under the scheme is either $\$ 1,000$ for foreign currency deposits or the equivalent of $\$ 1,000$ (calculated at the official rate) in rubel. Deposits made by a single individual are aggregated for the purpose of this calculation.

\section{Proposed changes}

A draft new deposit insurance law has been prepared by a NBB working group. This envisages the creation of a deposit insurance corporation that will assume responsibility for managing a dedicated deposit insurance fund invested in government securities. The deposit insurance corporation will be run with the participation of the NBB, the banks and representatives of the relevant government ministries. (The involvement of the banks in nunning the scheme may give rise to conflicts of interest, and their role should ideally only be consultative. The extent of their proposed involvement is at present unclear). Both foreign currency and rubel deposits will be covered, up to a maximum of $\$ 1,000$ (or its equivalent in rubel) as at present. Since the fund's assets will be invested only in rubel-denominated securities, it will be exposed to foreign exchange risk.

A number of issues remain to be resolved, including whether the corporation should be provided with a contingent line of credit by the Finance Ministry to meet exceptional periods of demand on the fund. A further issue concerns whether the new scheme should be applied to all banks, including the core institutions. A deposit insurance scheme applying to all banks would minimize competitive distortions, but it is questionable how credible the limitation on deposit payouts would be, given the extent of state ownership of the core banks. In any event, the continuing fragile state of the banking sector and the lack of macroeconomic stability suggests that it would be inappropriate to introduce a new scheme at this juncture.

71. The NBB has also recently introduced large exposures limits, which normally require a loan to an individual borrower not to exceed 25 percent of a bank's capital. Rules on insider lending have also recently been introduced. These limit the amount that a bank can lend to all of its shareholders to 100 percent of its capital and to any one shareholder to 10 percent of capital. However, the limit on related-party lending is much higher than is the practice in most other countries, and an aggregate limit of 10-15 percent of capital is more usual. Permitting the bank's owners to borrow an amount equal to shareholders funds casts into doubt the extent to which these funds are genuinely available to meet losses.

72. Minimum paid-in capital requirements have been set at euro 2 million for national banks and euro 5 million for foreign shareholder banks with more than 20 percent foreign 
ownership. Given the high degree of dollarization in the banking system (see Chapter IV), banks are being encouraged to hold at least some of their capital in foreign currency, but this is by no means universal.

73. Despite some progress in developing a prudential framework for banks, important deficiencies in supervision remain. The NBB's self-assessment against the Basel Committee's Core Principles for Effective Banking Supervision highlights a lack of consolidated supervision ${ }^{27}$ as a major deficiency in the supervisory regime. In addition, responsibility for monitoring banks' foreign exchange exposures resides with the NBB's foreign exchange department rather than the banking supervision department. Since this prevents bank supervisors from forming a fully comprehensive risk assessment, it would be advisable for the monitoring of foreign exchange exposures to be transferred to banking supervision as soon as possible. Finally, although the prudential rules promulgated by the NBB appear relatively sound on paper, there is some evidence to suggest that they are not being applied consistently, and ad hoc exemptions from prudential requirements appear to be readily granted. For example, the large exposures lending limits do not seem to be widely enforced.

74. Following high levels of staff attrition in 1995-96, banking supervisors are now paid a twenty percent premium over other NBB staff. Staffing levels have since stabilized, but it is likely that much of the human capital built up through technical assistance pre-1996 will now have been eroded.

\section{Dollarization OF THE BELARUSIAN ECONOMY ${ }^{28}$}

75. The Belarusian economy is highly dollarized. ${ }^{29}$ Dollarization reflects the poor macroeconomic environment with high and variable inflation rates, but also a set of institutional characteristics that have encouraged the use of foreign currency rather than Belarusian rubels.

76. The demand for Belarusian rubels is inversely related to the level of inflation (Figure IV.1). ${ }^{30}$ The lack of financial instruments that preserve the real value of portfolios of

${ }^{27}$ This involves monitoring a bank's compliance with prudential requirements on a basis that takes into account all branches and subsidiaries of a bank (where the latter are of a financial nature).

${ }^{28}$ Prepared by Alfred Schipke.

${ }^{29}$ The term dollarization is used broadly to describe the substitution of domestic currency with foreign currency and short-term instruments in foreign currency.

${ }^{30}$ In principle, higher rates of inflation do not necessarily have to be associated with currency substitution. Countries with developed financial markets and instruments that allow 
residents has encouraged Belarusians to seck assets and instruments in foreign currency. As figures IV. 2 and IV. 3 show, the real return on local currency deposits turned increasingly negative over the past years while at the same time returns on foreign currency remained at around the same level, encouraging currency substitution.

Figure IV,1. Rubel Broad Money (In percent of nominal GDP)

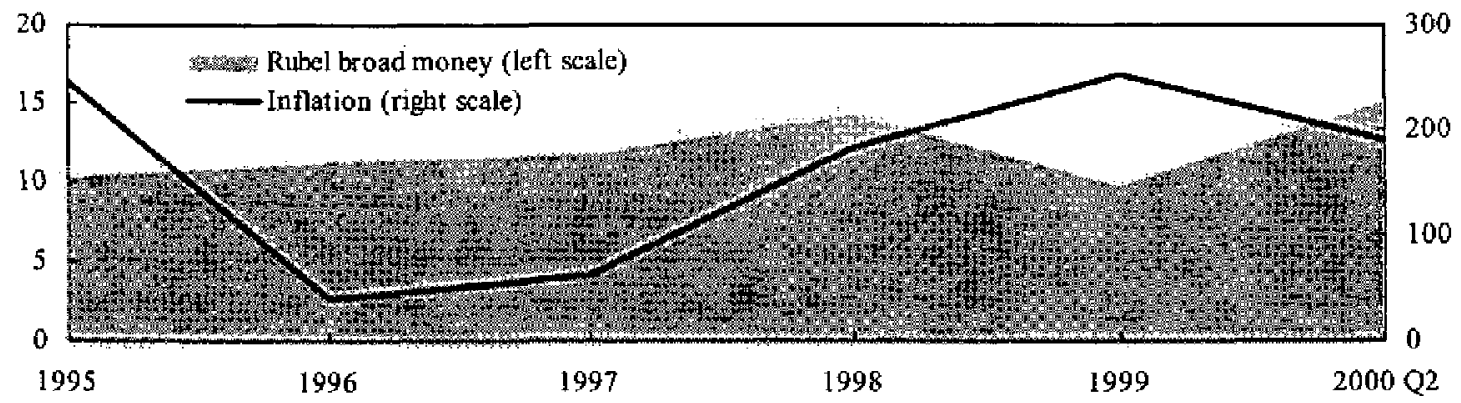

Source: Belarusian authorities; and Fund staff estimates.

77. To determine the full degree of dollarization would require estimates of foreign currency notes circulating in the country, as well as foreign exchange deposits of residents abroad. Reliable data for neither are available. However, in the case of Belarus, foreign currency deposits in the domestic banking system could serve as a proxy for the degree of dollarization. The incentive for capital flight-and hence the need to cover foreign currency deposits abroad - is large in countries that do not allow residents to maintain foreign currency deposits. In the case of Belarus, the authorities not only permit bank accounts in foreign currency but have been implementing policies that minimize the outflow of capital (see below).

economic agents to hedge against inflation are likely to experience less dollarization than countries with repressed financial markets. 
Figure IV.2. Interest Rate on Foreign Currency Deposits, Jan 1996-May 2000 (In percent per annum)

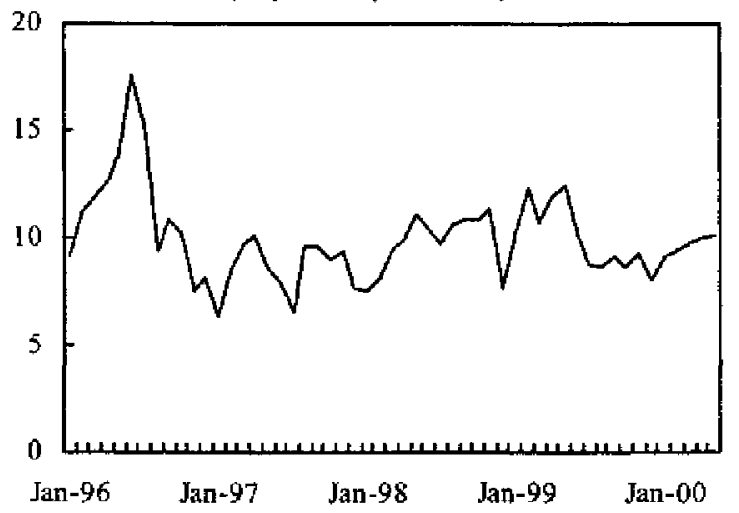

Figure IV.3. Real Domestic Currency

Deposit Rate, Jan 1996-May 2000

(In percent per annum)

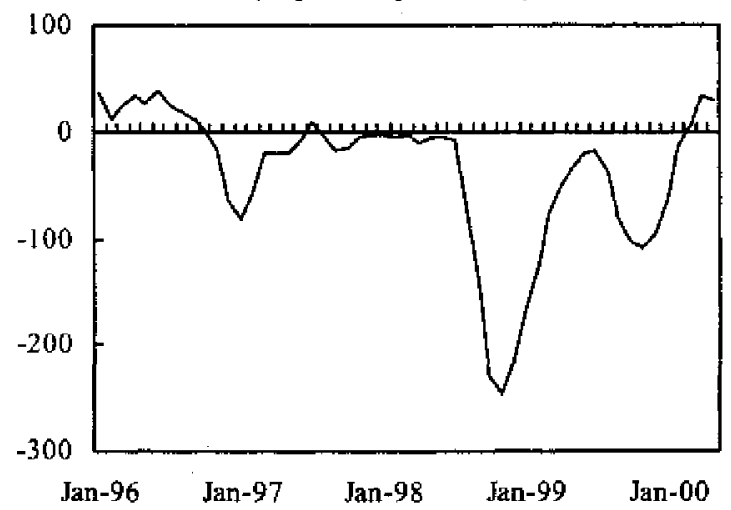

Source: Belarusian authorities; and Fund staff estimates.

78. The growing dollarization of the economy is mirrored in a sharp increase in dollar deposits in commercial banks, which rose from $\$ 479$ million at end-1995 to $\$ 690$ million at end-1999 (Figure IV.4). During the same period, the share of dollar deposits in deposits of commercial banks increased from 39 percent to 53 percent. The changes in this ratio are closely associated with the evolution of the level of inflation in the country (Figure IV.5). The inverse relation observed during the first months of 2000 is the result of the faster depreciation of the official exchange rate. The depreciation of the official rate in excess of the inflation rate reduced the ruble value of foreign exchange denominated deposits, thereby increasing the ratio of foreign currency as a percent of total deposits.

Figure IV.4, Foreign Exchange Depos its at Commercial Banks (In millions of U.S dollars)

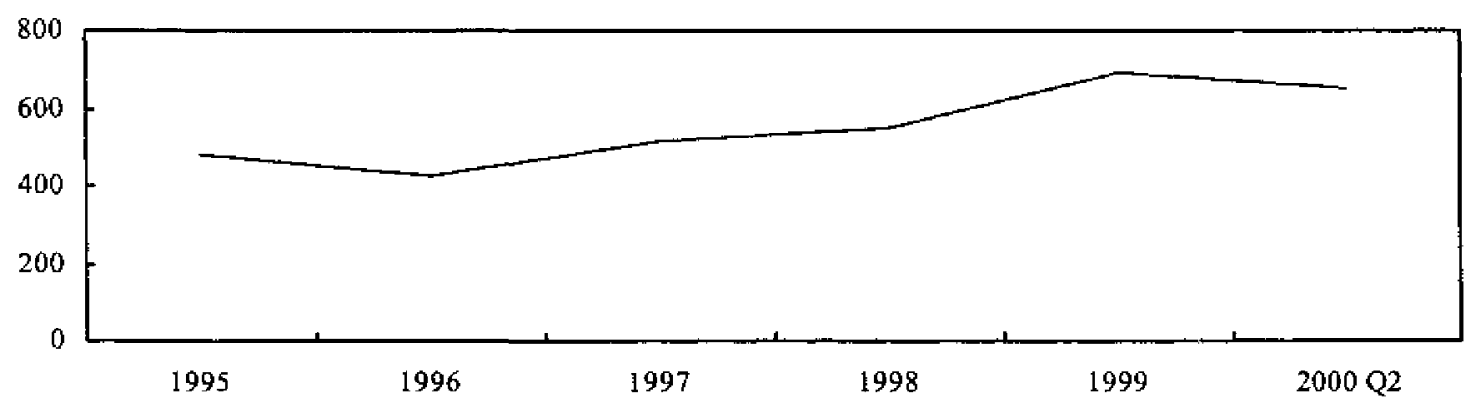

Source: Belarusian authorities; and Fund staff estimates. 
Figure IV.5. Foreign Exchange Deposits and Inflation

(Foreign exchange deposits as a percent of total deposits; end of period inflation in percent)

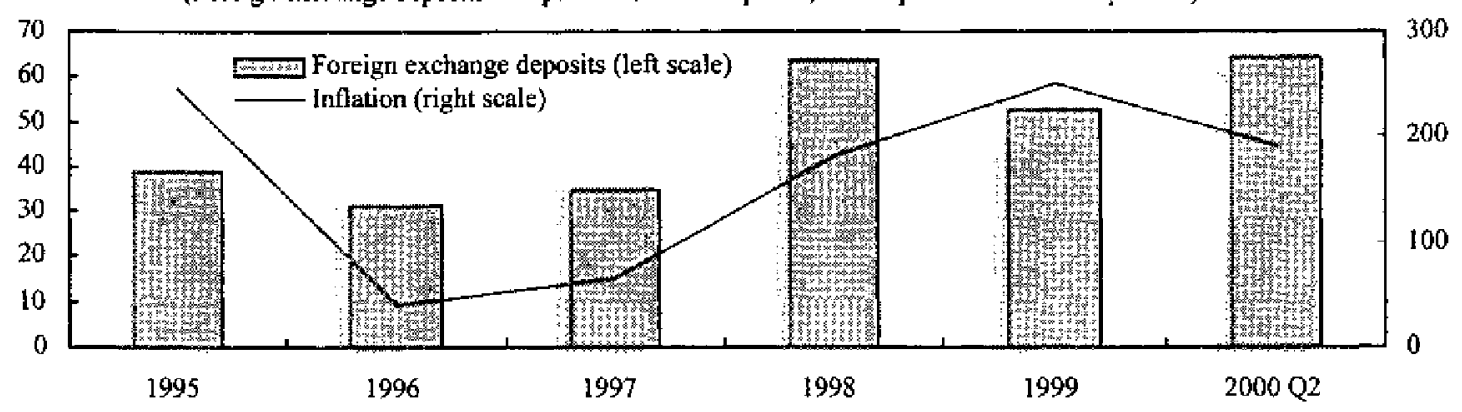

Source: Belarusian authorities; and Fund staff

79. The Belarusian authorities have attempted to limit the flight of capital by implementing a set of regulations that ultimately create an institutional bias toward the use of foreign currency. For example:

- A presidential decree in 1998 introduced an explicit guarantee for foreign currency household deposits. ${ }^{31}$

- Interest income from foreign currency deposits is tax exempt. Hence, the Belarusian tax system provides an incentive for people to use foreign currency as a store of value rather than domestic currency.

- The latest increase in statutory reserve requirements, effective from February 2000, applies to domestic currency deposits only. While the reserve requirement on domestic currency deposit was raised to 19 percent, the one on foreign currency deposits remained at 16 percent. This asymmetric treatment of deposits provides an incentive for banks to attract more foreign currency deposits.

80. Both the explicit guarantee on foreign currency deposits and the asymmetric incentive system favoring foreign currency deposits are intended to tap the population's foreign exchange reserves and to ease pressure in the parallel foreign exchange markets. The latter became very important as the Belarusian authorities tried to eliminate the multiple exchange rate system by depreciating the official exchange rate more rapidly.

${ }^{31}$ To what degree the announcement of an explicit guarantee contributed to a portfolio change toward foreign currency deposits depends on to what degree depositors of domestic currency assumed their deposits to be guaranteed as well. Despite the weakness of domestic banks, the public has not lost confidence in the system. It could be concluded then, that depositors implicitly expect to be bailed out. 
Figure IV.6. Minimum Reserve Requirements (In percent of eligible deposits)

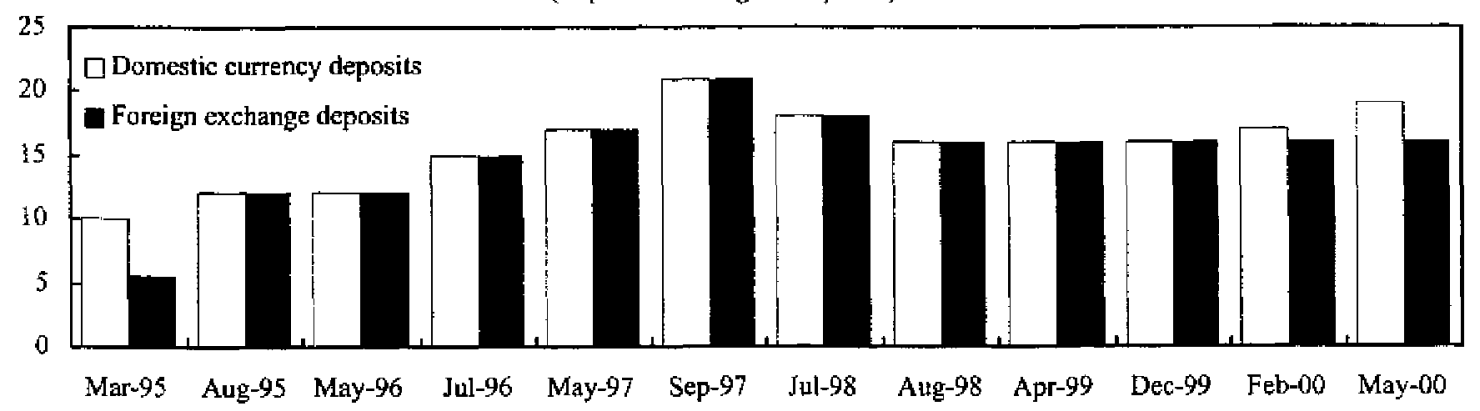

Source: Belarusian authorities; and Fund staff

81. Evidence of the degree to which a serious stabilization program would lead to an increase in the demand for real domestic balances and hence re-monetization of the economy has been rather mixed in other countries-especially in Latin America. ${ }^{32}$ There seems to be some evidence that the demand for real money balances after a reduction in inflation rates takes place only after a prolonged period of time. This suggests that once economic agents have started to economize on the use of domestic currency, a reversal is more difficult to bring about.

82. The recent evidence from Belarus, however, suggests that a serious stabilization effort could be associated with rapid re-monetization of the economy and hence an increase in the demand for real money balances. The reduction in monthly inflation rates and the return to positive real interest rates at the beginning of the year 2000 was immediately followed by a change the composition of bank deposits: domestic currency deposits increased, and foreign currency deposits fell by some $\$ 40$ million during the first half of 2000. This change in deposit composition took place irrespective of the asymmetric increase in statutory reserve requirements. The responsiveness of the demand for real domestic balances could, for example, be explained by the fact that while the Belarusian rubel lost its attractiveness as a store of value due to the inflationary environment, it is still widely used as a unit of account and medium of exchange. This is probably because the country has not experienced a prolonged period of an outright hyperinflation.

${ }^{32}$ See Savastano, Miguel A. 1996. Dollarization in Latin America: Recent Evidence and Some Policy Issues. IMF Working Paper WP/96/4. 


\section{BeLARUS-RUSSIA UNION ${ }^{33}$}

\section{A. Background}

83. The political and economic fortunes of Belarus have remained closely tied to Russia after the break-up of the Soviet Union. Russia is Belarus' largest trading partner, accounting for 50 percent of exports and 63 percent of imports during the first five months of 2000 . Transport service revenues of close to $\$ 1$ billion per year depend largely on the flow of goods between Russia and other countries. In addition, Russia's Gazprom is building a gas pipeline (Yamal) to Western Europe through Belarus. Investment in this pipeline accounts for more than half of Belarus' otherwise meager foreign direct investment. Russia also granted about $\$ 950$ million in debt relief to Belarus in 1997 and assumed about $\$ 2.5$ billion of old Soviet debt from Belarus.

84. Belarus is highly dependent on energy imports from Russia, gas in particular. Belarusian utilities routinely pay for the imported energy in barter, effectively boosting demand for Belarusian industrial products, such as tractors and refrigerators. In addition, Belarus is implicitly subsidized by Russia through toleration of arrears. In early June 2000 , public utilities owed $\$ 299$ million in overdue payables for gas and $\$ 106$ million for electricity. These arrears are usually settled in offsets with Belarusian industrial products.

85. Given its continued economic dependence on Russia and its growing isolation from the international community, Belarus has tried in recent years to strengthen its political and economic ties with Russia. This has not implied a radical change of political orientation, as most of Belarus' political elite has supported re-integration with Russia ever since independence.

\section{B. Interstate Agreements and Institutions}

86. After a number of bilateral agreements were signed between April 1996 and December 1998, the union idea gathered momentum in 1999, culminating in the December agreement to form a unified state. This Union Treaty has been ratified by both parliaments and was followed by a wave of high-level meetings, the inception of a number of joint institutions, and the preparation of implementation plans.

87. Implementation plans are being drafted to set out a roadmap for economic integration during 2000-2005. According to the proposed timetable, harmonization of civil and economic legislation should proceed as follows: price regulations will be harmonized by 2001; a unified tax code will be established by 2002; the foreign trade and customs regime will be harmonized by 2005 ; transport, energy and telecommunications will be harmonized by 2005 ; monetary union will be established by 2005 .

\footnotetext{
${ }^{33}$ Prepared by Christian Mumssen.
} 
88. Several institutions supporting the process toward political and economic union have been set up:

- The Supreme State Council includes the presidents, the prime ministers, and the heads of parliament.

- The executive body, the Union Council of Ministers, encompasses the cabinets of ministers of both countries.

- The Standing Committee of the Union government has been set up to prepare the meetings for the two councils.

- An Interbank Currency Council, representing the two central banks, has been set up to prepare monetary union.

89. Further institutions are planned, including courts and a union parliament. The parliament would have two chambers, with a lower chamber of 75 Russian and 28 Belarusian delegates, and an upper chamber made up of equal numbers of representatives from both countries. The Supreme State Council and the Union Council of Ministers during the first half of 2000 approved the Union's first "budget" of RR 2.3 billion (about $\$ 80$ million).

\section{Economic integration}

90. Despite the proliferation of joint political bodies, the Union Treaty signed in December 1999 foresees primarily an economic rather than a political union. Both countries would retain their sovereignty and the only binding pieces of joint legislation would be those in the economic sphere. In that sense, the Union is based on similar principles as the EU, a framework favored by the Belarusian side. However, there are different perceptions on whether the union with Russia could or should be a union of equals. Ultimately, economic integration could depend on Belarus' ability and willingness to adopt Russian legislation and achieve macroeconomic stabilization.

91. In the near term, economic integration is to be fostered by the development of a unified economic data system, an economic development program, a program for support of small and medium-sized enterprises, and a harmonized system of civil legislation. Furthermore, to prepare for monetary union, draft laws have to be written on foreign exchange regulations, taxation, customs union, securities markets, price regulations, energy policy, and transport systems. In some cases, the new legislation would necessitate changes to the two national Constitutions, making integration most likely a lengthy process.

\section{Customs harmonization}

92. The customs union is a work in progress, with the aim of full harmonization by 2005 . Five countries (Russia, Belarus, Kazakhstan, Kyrgyz Republic, Tajikistan) form a "customs union", although there are still numerous restrictions, including in the customs union between 
Russia and Belarus. There are currently no tariffs or quantitative restrictions on trade between Belarus and Russia. However, even this free trade area is not complete. Belarus maintains controls on export prices of goods that are subject to domestic price regulation, mainly meat, dairy and leather. After Russia imposed tariffs on imports from third countries on transit through Belarus in March 2000, Belarus introduced in August a similar regulation for Belarusian imports on transit through Russia.

93. Tariffs applied to imports from third countries are almost fully unified. Notable exceptions are medicines and food products where different tariff rates apply. There are plans to finalize a common tariff schedule, perhaps as early as this year. Quantitative restrictions on trade with third countries differ between Russia and Belarus. Belarus maintains export restrictions on fertilizer, scrap metals, copper, aluminum and a number of other goods. Russia has a different list of goods subject to export restrictions and there are no immediate plans to unify the two lists.

\section{Tax harmonization}

94. A unified tax code is supposed to be finalized by the end of 2002 . According to the Ministry of Finance, the two systems are already very alike. The planned tax reform in Russia is likely to lead to similar changes in the Belarusian system, although Belarus is leaning against adopting certain rules from Russia.

95. On income tax, Belarus is likely to introduce a flat rate that would be close to Russia's 13 percent. Belarus currently has a more progressive system with income tax rates ranging from 9 to 30 percent, although the effective tax rate is only about 11 percent. With the elimination of a number of exemptions and benefits, the Ministry hopes that the introduction of a flat rate would not lower the effective income tax rate.

96. On VAT, Russia and Belarus have the same tax rates, with a normal rate of 20 percent, a reduced rate of 10 percent for a few goods, and a zero rate for exports. Trade with Russia still follows the principle of origin rather than the internationally common destination principle, leading to inconsistencies in the system.

97. Profit taxes are similar in the two countries- -25 percent in Belarus and 30 percent in Russia. Russia is currently preparing a reform of enterprise taxation that Belarus may follow in some aspects. However, there is doubt whether Belarus will change depreciation rules from linear to geometric, which would allow a lower tax burden soon after capital expenditures. The authorities are also reluctant to allow advertising expenditures as eligible costs for tax purposes.

98. The list of goods subject to excise tax is virtually identical in both countries, the main exception being diesel fuel, which is exempt in Russia. However, excise tax rates are generally different, partly because of the very different structures of the two economies, with Russia relying heavily on natural resources, whereas Belarus draws 70 percent of excise tax 
revenue from vodka sales. Excise taxes are calculated ad valorem in Russia, while Belarus adheres to a system based on euros per physical unit.

\section{Monetary union}

99. The implementation plan for economic integration foresees monetary union by January 1,2005 . The common currency will be the Russian ruble, which by 2008 would be converted into a Union ruble. The implementation process is overseen by the Interbank Currency Council. No agreement has been reached on whether the monetary authority would be the Central Bank of Russia (CBR), or whether the CBR and NBB would act under the leadership of the Interbank Currency Council. Belarus would need a constitutional amendment if the CBR would be the sole monetary authority.

100. Monetary union would require convergence of macroeconomic performance and policies. At this point, this would imply that Belarus would have to bring inflation down to Russian levels and undertake a number of liberalization measures. As a first step, Belarus would unify the various exchange rates and remove foreign exchange restrictions, establishing convertibility on current account transactions. Further, the NBB would be endowed with greater independence and report to parliament. Russia would support these efforts by providing a stabilization loan of Russian Rbl 4.5 billion (about $\$ 150$ million) to boost the NBB's gross reserves. The exchange rate regime Belarus would follow in the runup toward monetary union is likely to be a managed float, with the objective of avoiding a deterioration in external competitiveness. Inflation is expected to gradually come down to Russian levels by 2005 .

\section{Outlook}

101. Although the bilateral agreements between Belarus and Russia are ambitious in tone, overall progress in economic and political integration has been limited so far. The most concrete result has been the establishment of joint institutions with few de facto executive powers. For both sides, the Union has important symbolic value, given Belarus' relatively isolated position in the international community and Russia's role as a regional center. However, differences in the approach to economic policy and political institutions may be obstacles. Even if these differences could be resolved, the implementation schedule for economic and monetary union would still be ambitious on purely technical grounds.

102. Although it is unlikely that a unified state would emerge in the near future, there are important economic consequences of the ongoing integration process. Further progress in tax and customs harmonization would strengthen economic relations and boost trade and crossborder investment between the two countries. The Belarusian economy is likely to benefit from access to Russia's large consumer market and from potential investment by Russian firms in Belarus.

103. More importantly, monetary union with Russia requires a revision of macroeconomic policies and some important economic reforms in Belarus. This would entail a substantial 
tightening of monetary policy to bring down inflation, liberalization of the foreign exchange markets, and sufficient fiscal discipline to support a disinflationary monetary policy. These policy goals would require an overhaul of the current economic regime that has so far relied on price and exchange regulations, as well as central bank financing, to support sectoral programs such as housing and agriculture. Moreover, the establishment of a common market-an economic pre-condition for successful monetary union-would require the harmonization of pricing policies, thus forcing Belarus to liberalize prices.

104. The process of preparing for monetary union with Russia therefore implies a big shift in economic policy for Belarus, toward market-oriented transition. Whether monetary union will be achieved in the end depends partly on whether Belarus will pursue the necessary economic reforms and macroeconomic policies, and partiy on whether Belarus would be willing to surrender monetary policy independence once it has successfully established macroeconomic stability.

\section{BUSINESS ENVIRONMENT ${ }^{34}$}

\section{A. Introduction}

105. Belarus has pursued an economic strategy that differs significantly from the marketoriented reforms in other transition economies. Its model of a "socially-oriented market economy" has de-emphasized liberalization and private ownership, while focusing on the provision of finance to priority sectors of the economy. Industrial and agricultural production have been supported through explicit and implicit subsidies channeled to state-owned enterprises, partly through the banking sector, but also through extensive state regulations and interventions in prices and business operations. These interventions have included:

- $\quad$ Price and wage controls, in particular ceilings on price increases, as well as a rigid wage grid;

- Foreign trade and exchange restrictions, in particular the multiple exchange rate system;

- Administrative restrictions, in particular the repeated enterprise re-registration process and high barriers to new business formation;

- An unstable legal and regulatory environment, including erratic economic policies and frequent state interventions, including formal and informal "recommendations" by the state, which tend to penalize profitable private enterprises and cross-subsidize unprofitable companies.

\footnotetext{
${ }^{34}$ Prepared by Christian Mumssen.
} 
106. These various forms of state intervention have undermined the business environment in Belarus. They have provided short-term arbitrage opportunities between various controlled and uncontrolled market segments, diverting firms' attention away from long-term business development and investment. This has not only stifled private sector growth, it has also pushed many firms into the gray economy, which the International Finance Corporation (IFC) estimates at 60 percent of the official economy among small and medium-sized firms. Previous studies have put the total gray economy in Belarus at around 20-25 percent of GDP in the mid-1990s, somewhat below most other CIS economies. ${ }^{35}$ Private sector expansion is also constrained by an extremely sluggish small-scale privatization process.

107. Partly as a result of the unfavorable investment climate, the profitability of enterprises has continued to decline. According to the Ministry of Economy, profitability of enterprises fell from 15 percent during the first five months of 1999 to 11 percent in the same period in 2000 . For industry, the corresponding drop was from $18 \frac{1}{2}$ percent to 14 percent. The number of loss-making enterprises rose from 21 percent in the first five months of 1999 to 32 percent in 2000 . For industry, the corresponding increase was from 11 percent to 28 percent. Overdue payables of enterprises grew by 20 percent in real terms during the first quarter of 2000 , reaching 21 percent of GDP.

108. There are few signs of market-oriented enterprise restructuring. The large state enterprises in industry and agribusiness survive mainly through access to subsidized loans and energy, as well as through barter deals with other CIS countries. The government lacks a clear strategy for privatizing enterprises, although it is not adverse to the idea of attracting foreign investors. However, there is little hope of any significant foreign direct investment as long as the basic constraints remain in place.

\section{B. Barriers to Private Sector Growth}

\section{Price and wage controls}

109. Extensive price and wage controls affect all enterprises in Belarus. Apart from basic food items, prices are regulated for products of 26 "strategic enterprises" in sectors such as fertilizer, glass and cement. Moreover, all products are subject to ceilings on price increases that are determined by the Council of Ministers for each sector. In January 2000, monthly ceilings were set at 7 percent for most sectors, 5 percent for food products, and 17 percent for the oil industry. Quarterly ceilings for the second half of 2000 range from 15 percent for fuel, chemical products, and some food sectors to 35 percent for bread products. If a company plans to increase prices by more than that, it needs to apply half a month in advance to the local price committee, which routinely passes on these requests to the Price Committee in the Ministry of Economy. Permissions are granted only in exceptional cases. If a firm raises

${ }^{35}$ This discrepancy may be explained by the fact the agro-industrial complex in Belarus has not yet been dismantled, in contrast to other CIS countries. 
prices above the normative ceiling without applying for a permission or without obtaining the permission, it has to pay fines equaling three times the difference in revenues.

110. The system of periodic price ceilings jeopardizes the health of the enterprise sector, especially in an environment of high and volatile inflation. If inflation rises above the monthly ceiling, there is an automatic squeeze on enterprise profitability. The bureaucratic hurdles for seeking permission for each above-ceiling price increase deter most enterprises from applying in the first place. Moreover, some firms may raise prices in low-inflation months above optimal level in order to build a cushion for future months with potentially higher inflation. The policy is therefore also ineffective as a measure to contain inflation. Moreover, it drives enterprises into the gray economy.

111. In addition to widespread price controls, the state continues to regulate wages, setting not only ceilings and floors, but also salary structures. All companies remaining in state ownership have to employ the public-sector "grid" of pay scales that is expressed in multiples of the minimum wage. If a firm wants to reward a particular employee with a pay increase, it would have to shift the entire pay scale for the firm upwards, for all employees. In addition, all firms-state-owned and private-have to keep pay increases in line with inflation and enterprise profitability. These regulations encourage side payments to productive employees, which in turn tends to undermine tax revenues.

\section{Controls on foreign trade and exchange}

112. Belarus has a relatively specialized economy that depends heavily on foreign trade (for the year 2000, exports are estimated by the staff to reach 70 percent of GDP, imports 80 percent). The principal imports are grains, oil and gas, as well as consumer products, while the main exports are manufacturing goods, especially household products and transport vehicles. Despite the importance of foreign trade, the state maintains extensive restrictions on foreign trade and exchange, although there were a number of important liberalizing measures in late 1999 and early 2000 (Appendix I).

113. The import tariff regime is in line with international practice. Tariffs range from 0 percent to 30 percent for most goods and the weighted average import tariff is 10.5 percent. Belarus maintains free trade with Russia, Kazakhstan, the Kyrgyz Republic, and Tajikistan. However, it imposes quantitative export restrictions on a number of products, such as fertilizers, scrap metals, copper, and aluminum. There are also minimum prices on exports of meat, dairy, and a number of other products. This measure is partly a reflection of the price controls in the domestic market, with the intention to prevent the export of subsidized basic consumer products. However, these minimum export prices create an indirect export tax on relatively more efficient producers and incentives for smuggling.

114. The most damaging restriction on foreign trade and exchange has been the multiple exchange rate system, coupled with the 30 percent export surrender requirement. At the beginning of 2000 , the Belarusian rubel was worth three times more at the official than at the parallel market rate. Surrendering export proceeds at the official rate thus amounted to an 
implicit export tax of 20 percent, drastically reducing the competitiveness of Belarusian exports. However, as a result of numerous exemptions, the effective surrender rate has been in the range of 14-15 percent, rather than 30 percent. Apart from exempting individual firms, there are no surrender requirements on exports in local currency (although these were themselves prohibited until early 2000). Barter exports are also exempt, providing strong incentives for this untransparent way of conducting foreign trade. A 15 percent fee on barter transactions (or 5 percent if raw materials are imported at the same time) imposed in June 1999 was suspended in August 2000.

115. The liberalization of the cash market and the second session of the Belarus Currency and Stock Exchange (BCSE) in late 1999/early 2000, as well as the accelerated depreciation of the official exchange rate in the first half of 2000 , have contributed to increase demand for Belarusian rubels and virtually eliminated the black market. However, remaining restrictions, such as on imports in Belarusian rubels, as well as the persistence of multiple exchange rates and surrender requirements, continue to provide incentives for gray market activities and arbitrage rather than for developing long-term trading ties and investment in upgrades and new products lines that could expand the export market.

\section{Administrative controls}

116. Further to price and foreign exchange controls, enterprises are constrained by extensive administrative controls. Among them is the process of repeated re-registrations for all businesses. The most recent (third) round required enterprises to re-register by January 1,2001 . The conditions attached to re-registration are difficult to achieve for many small enterprises. As a result, after more than a year of registration under this round, only about 15 percent of enterprises had re-registered. To register, firms need to specify and later adhere to business plans and lines of business. If these plans are not executed, the local registration authorities can withdraw the business license without going through the court system. Withdrawal of business licenses is also possible whenever a firm is loss-making for more than three months.

117. New business formation is constrained by the same registration hurdles. In particular, minimum capital requirements suppress the emergence of small firms. Capital requirements are about $\$ 15,000$ for limited liability companies, and $\$ 50,000$ for joint stock companies. It is generally difficult to limit personal liability when setting up a new firm, which makes new ventures particularly risky for entrepreneurs. Moreover, all business activities are subject to cumbersome licensing procedures.

118. In addition to the complicated registration process, the state maintains a regime of tight controls and reporting requirements. Firms have to submit a minimum of 22 reports per year, mainly to tax authorities. There are additional regular reporting requirements to the statistical office. Moreover, enterprises are subject to frequent inspections, usually around 10 per year, up to 20 for some firms. 
119. The wide-ranging administrative barriers and complex regulations are particularly difficult to cope with for small and medium-sized companies that have little recourse to the local authorities. The over-regulation of the private sector also tends to foster corruption, although this is deemed to be less of a problem than in neighboring countries. The government has recently set up a commission to study the regulatory environment. As a first step, the government has been preparing a number of measures to simplify business registration and licensing, for small enterprises and foreign investors. In addition, it is considering simplifications of accounting and tax rules for small businesses.

\section{State intervention and legal environment}

120. The unstable legal and regulatory environment, inchuding frequent ad hoc interventions by the state, is seen as particularly damaging for private sector growth. Legislation and regulations are perceived as generally anti-business. Trading companies and other intermediaries are viewed with suspicion by the authorities. In addition, legislation and regulation are subject to frequent change, creating uncertainty and deterring investment.

121. The tax system also creates a number of problems for enterprises. Although tax rates are not unusually high, the system is fairly complex, following mostly the Russian example. While the profit tax rate is only 25 percent, not all costs are deductible, including advertising, which is not seen as a necessary business expense. In addition, the use of a linear depreciation nile for tax purposes tends to keep taxable income relatively high compared to other countries that allow faster depreciation.

122. The state also sometimes intervenes in business operations without a legislative basis. The local and national authorities frequently use discretionary campaigns in the form of formal or informal requests and recommendations to extract "contributions" from profitable firms. Such discretionary taxes are often used to support loss-making enterprises (especially in agriculture) or to finance local public investment. The most prominent recent examples were a resolution by the Council of Ministers in March 2000 to provide aid to state and collective farms by requesting all government agencies, banks, and state enterprises to "adopt a farm", as well as a presidential decree in May 2000 to establish off budget housing investment funds, financed by contributions from enterprises amounting to 0.5 to 1 percent of their revenues. Similarly, the surrender requirement was temporarily augmented by another 10 percent during March and April 2000 to finance oil imports for agriculture. Banks have recently been asked to provide $\mathrm{Rbl} 35$ billion in lending to agriculture, which they have been doing by selling their foreign exchange reserves to the central bank.

\section{Privatization and Foreign Investment}

123. The government continues to pursue a strategy of gradualism in privatization. After almost a decade of transition, little more than half of small enterprises have been privatized. This contrasts sharply with the experience of other transition economies where small-scale privatization only took a few years to complete. Only about 50 percent of vouchers issued to the public have been used so far. In trade and light industry, about 70 percent of firms have 
been privatized, more than in many other sectors. Some progress was made with technical assistance from the IFC, although this project has now expired. The Ministry of Privatization maintains that budget cuts and weak demand for service companies in remote locations have slowed down the process of small enterprise privatization. The privatization of small firms is usually the responsibility of local authorities, as most property in this category is communal rather than republican. Although revenues from the auctions and tenders thus accrue to local budgets, local governments are often unable to sell off the property, given low purchasing power of citizens and employees and the need to get the approval of the work collective.

124. Progress in large enterprise privatization has been minimal. Although many firms have been converted into joint stock companies, most remain majority state owned. The Ministry of Privatization generally decides on the method of privatization on a case-by-case basis, specifying the sales price and the allocation of share to workers, investors and residual state ownership. Privatization can only go ahead when a business plan is approved that ensures continued production and employment. Some 960 firms are excluded from privatization altogether. Moreover, since the privatization of large, "town-forming" enterprises requires the initiative of the workers collective, all of these enterprises have remained in state ownership.

125. The government hopes that foreign capital will support the privatization and restructuring process. However, the current procedures and the general investment climate are not conducive to attracting investors. The stock of FDI in Belarus amounted to \$697 million at the end of 1999, of which the lion share related to the Yamal pipeline, a project by Russia's Gazprom to export gas to Western Europe. The European Bank for Reconstruction and Development (EBRD) puts Belarus in 23 rd place of 25 transition economies, with cumulative net FDI inflows from 1989 to 1998 of $\$ 45$ per capita, higher only than in Tajikistan and Uzbekistan. In mid-2000, the government set up a foreign investment council to work out recommendations for attracting foreign investors.

\section{Social SafeTY NeT ${ }^{36}$}

\section{A. The Current System}

126. The relatively large social programs in Belarus have not succeeded in significantly reducing poverty. Living standards have fallen for most households since the breakup of the former Soviet Union. About 33 percent of the population are estimated to live below the poverty line, ${ }^{37}$ although the cost of different social programs, excluding outlays on education

\footnotetext{
${ }^{36}$ Prepared by Joerg Zeuner.

${ }^{37}$ In terms of data and unless otherwise indicated, this section refers to a 1999 FAD technical assistance report on social protection in Belarus.
} 
and health, exceeds 30 percent of GDP. ${ }^{38}$ Poverty is concentrated among households who have three or more children or have unemployed members. A large share of total spending is on pensions, followed by foreign exchange subsidies due to the multiple exchange rate practice and income support for private households.

127. The failure to address poverty effectively has primarily resulted from a proliferation of small benefits to the majority of the population, which are not well-targeted to the poor. Leaving aside pensions (see below) and foreign exchange subsidies (see Appendix I), these benefits feature most prominently the gains from formal price controls. A weighted 25 percent of the goods and services in the CPI basket are subject to price regulation.

128. Price controls continue to be pervasive in Belarus. First, socially-important goods, mainly food products, are regulated. More importantly, housing rents, communal service tariffs, transportation services, and communication services are also controlled. In July 2000 , the monthly rent for a 100 -square meter apartment was, for example, limited to about 50 cents. ${ }^{39}$ The cold water and sewer service rate stood at 3 cents per cubic meter during the same period. Hot water cost about 65 cents per gigacalorie of heat spent, and the gas rate was set at 7 cents per tenant per month (measured at the parallel exchange rate). Households covered less than 25 percent of the costs of housing and communal services during the first six months of $2000 .^{40}$ Low cost recovery has led to large-scale wastage for all regulated goods and services.

129. An expensive system of direct and indirect subsidies ensures the availability of controlled items in a high inflation environment. ${ }^{41}$ Direct subsidies have been provided for agriculture and public enterprises. Agricultural subsidies include payments for fertilizers, pesticides, leasing machinery, drainage, and veterinary medicines. The basic objective of these subsidies is to equalize production costs between areas with varying soil quality. Apart from income support to farmers, agricultural subsidies also aim at containing prices of socially important goods. Direct subsidies to public enterprises are extended to the communal services sector, transportation, and communication. The transfers cover the difference

${ }^{38}$ FAD estimates that targeted spending of about 1 percent of GDP could eliminate poverty in Belarus, a small amount in relation to the current annual spending on various social programs.

${ }^{39}$ The average monthly wage amounted to $\$ 59$ at end-June, 2000 .

${ }^{40}$ In 1999, the cost-coverage of housing and communal services was even lower, below 18 percent on average, ranging from less than 11 percent for rent to almost 50 percent for sewerage.

${ }^{41}$ Producer prices have been rising by about 170 percent per year on average over the last three years. 
between the costs of production and the tariffs paid by users. They amounted to about 1 percent of GDP in 1999.

130. Indirect subsidies have included large cross-subsidies and subsidized credit. Communal services, transportation, and communication have been the main recipients of cross-subsidies. They have taken the form of differential pricing for different types of users. Non-residential users, typically enterprises, have been charged higher tariffs than residential users, mainly private households. Cross-subsidies were estimated at 4 percent of GDP in 1999. The burden of cross-subsidies on enterprises has squeezed their profit margins, with an adverse impact on their productivity and competitiveness. In 1999, the banking systemincluding the NBB - provided credit at preferential rates for housing construction, the agricultural sector, and selected manufacturers. The cost of subsidized credits totaled 3.5 percent of GDP in $1999 .^{42}$

131. The system of subsidies has been costly for Belarus. Total subsidies have been rising and amounted to at least 18 percent of GDP in 1998. Budget sector subsidies, together with profits forgone by the NBB due to credit subsidies, came up to more than $61 / 2$ percent of GDP in 1998. The cost of the subsidy system for enterprises through cross-subsidies and the surrender of currency from exports at preferential rates amounted to $11 \frac{1 / 2}{2}$ percent of GDP during the same period. Although no precise calculations are available for 1999 , there is no evidence that the level of subsidies declined in relation to the previous year.

132. The Belarusian pension system is severely compressed, providing a minimum level of protection for all pensioners under difficult financial and demographic conditions. The pension system covers about 2.5 million pensioners, implying a dependency rate of 50 percent. Based on current contribution rates and defined benefits, the social protection fund is actuarially unsound. In view of financial difficulties, the original objective of replacing at least 55 percent of a worker's average wage, has been dropped. To reduce pension costs, the formula was adjusted downward to drastically reduce replacement rates for higher income workers. Since lower-income workers are guaranteed a minimum pension, the replacement rate for these workers was well in excess of 100 percent in 1999 .

133. The government also manages the distribution of a number of family benefits. Besides pensions, social insurance contributions have been used to fund child allowances for children under 3 years of age. In addition, budgetary resources have been used for financing allowances for children in low-income households between the ages of 3 and 16 , invalid child care, mothers of babies under $1 \frac{1}{2}$ years old, and maternity and childbirth benefits. Finally, benefits have also included ad hoc exemptions from utilities payments, such as granting free housing to war veterans.

${ }^{42}$ Subsidies for purchase of foreign exchange account for nearly 50 percent of total subsidies. As explained in Appendix I, exporters are required to surrender 30 percent of their foreign exchange earnings to finance priority imports at the accounting rate set by the NBB. 


\section{B. The Reform Agenda}

134. The government recognizes the unsustainability of the country's social protection system, which has performed poorly, created disincentives to work, and has been a burden on the budget. Moreover, the costs of operating the current system when deregulating the exchange rate and eventually liberalizing domestic prices would almost certainly have serious adverse effects on macroeconomic stabilization. Therefore, in March 2000, the Council of Ministers approved a revision of the country's social protection system.

135. Social safety net reform is planned to be carried out in two stages. In the first stage, during 2000 and 2001, the government intends to prevent a further decline in the living standard of the population, strengthen the system of minimum social guarantees, and enhance targeted social support for population groups that are in need. In the second stage, from $2002-2005$, the government plan is to divide the country's social protection system into two organizationally independent systems: social insurance and social assistance.

136. Phase one of the reform started with a focus on social assistance, with a view to providing a targeted $10-15$ percent of the population with income support. A targeted social safety net was adopted by the government on May 29, 2000, and is expected to become operational on January 1, 2001, with technical support from the Word Bank. Current estimates suggest that about 700,000 people would be eligible to transfer payments under this scheme. The costs for 2001 are estimated at $\$ 16$ million. Given the large share of wage and wage-related payments in total household income, income will be the principal determinant of eligibility for benefits under the new system. A household or individual will be eligible for social benefits if their average per capita income for the three months preceding the month of their application for assistance does not exceed 50 percent of the subsistence level budget, which determines poverty in Belarus.

137. The income criterion will be supplemented with other characteristics of poor households, narrowing the number of eligible beneficiaries. Eligible to targeted social assistance under the new scheme will be households with members who by virtue of their physical condition and financial and domestic circumstances require social support. Currently, these include most prominently single pensioners, single parents with children under age 16, families with three or more children, families with disabled members, and households with members over the age of 80 who require constant outside assistance.

138. The envisaged social protection system will be application-based and require households to forward income declarations. At the same time, it will be targeted, thus breaking with the tradition of widespread but small benefits that also supported the non-poor. Most importantly, by linking the scheme to the subsistence level budget, social benefits are protected against inflation and the adverse income effects of price liberalization. The subsistence level budget is reviewed and adjusted every quarter according to price developments. 
139. The targeted social protection system will allow the government to consider a phased reduction of subsidies. Thus, for housing and communal services, the government has already announced target rates that would cover 25 percent of total costs by the end of 2000 . The cost recovery rate should increase to 50 percent by end-2001, reaching 80 percent at end2002 , eliminating budgetary support and cross-subsidies afterwards.

140. With respect to the pension system, reforms have not yet started. However, the intention is to introduce a three-tier system by 2003 . Social pensions would be paid out of the state budget as benefits to persons who did not contribute to any kind of pension insurance system. A pay-as-you-go system based on mandatory contributions would provide the core pension, supplemented by a capital-based voluntary insurance scheme. Payments and contributions to the mandatory pension system would be determined according to the principles of financial soundness, length of employment, length of insurance coverage, and the size of the contributions.

\section{AGRICULTURAL REFORM ${ }^{43,44}$}

141. The agriculture sector continues to play a key role in the Belarusian economy, accounting for approximately 15 percent of output and employment. Its performance has been negatively impacted in recent years by difficult weather conditions, which have exacerbated growing underlying financial and operational weaknesses among agriculture producers. State support for the sector averaged $\$ 250-300$ million per year during the 1990s, approximately 3 percent of 1999 GDP or one-fifth of sectoral output. State support has come directly from the budget or from central bank credits channeled through local commercial banks, as well as indirectly in the form of subsidized fuel, foreign exchange and other inputs. The scale of state support is significant both in comparison with agriculture sector output and in terms of macroeconomic implications. Centralized credits channeled via commercial banks have created a legacy of bad debts, while cheap fuel and foreign exchange have acted to discourage reforms enacted elsewhere in the region.

142. During the past decade, few efforts have been made to dismantle or modify the system of collective and state farms, centralized financing and state supply and procurement, in favor of private agriculture development, marketing and finance. ${ }^{45}$ State involvement and

${ }^{43}$ Prepared by Mark Horton.

${ }^{44}$ This section draws on Farm Sector Restructuring in Belarus: Progress and Constraints, an ECSSD Technical Paper of the Europe and Central Asia Region of the World Bank, prepared by Csaba Csaki, Zvi Lerman and Sergey Sotnikov, May 17, 2000 (herein referenced to as the World Bank Report).

${ }^{45}$ The World Bank report identifies five critical actions needed to address sectoral weaknesses: a drastic reduction of government intervention, including abolition of price controls and procurement quotas; allocation of secure land use rights to individuals, rather 
controls are pervasive, including via direct ownership, state orders, and price, margin, and trade controls. A push on land reform during 1990-1993 was not sustained. Reform efforts have largely focused on improving organization and management, supplying farms with new equipment and encouraging greater specialization, without changing the current system.

\section{A. Background}

143. At the beginning of the $1990 \mathrm{~s}$, Belarus had approximately 2,500 state and collective farms. By the end of the decade, less than five percent of these farms had been formally reorganized into other legal forms. On the reorganized farms, changes have been mainly formal, with little internal restructuring or reorientation of labor, few gains in productivity, continued maintenance of a wide range of social functions, and little development of specialized marketing, technical or finance units.

144. Farms in Belarus undergoing restructuring are required to divide non-land assets among member-shareholders, but land is not divided. Land shares, which have been used throughout the CIS to give entitlement to land, are not employed. According to the World Bank, Belarus is the only CIS country outside Central Asia that does not allow for private ownership of all agricultural land. Only agricultural land in household plots of up to 1.0 hectare may be privately owned ${ }^{46}$ All other land for commercial farming remains stateowned, so that the pool of potentially privately owned land is limited to less than 20 percent. Concerning property distribution, of the 100 reorganized farms, official property ownership documents are held by individual shareowners in less than 15 percent of the farms, i.e., in less than one percent of all farms, with limited redemption and/or transferability.

145. The model of agriculture restructuring employed in central and eastern Europe and in some smaller CIS countries has aimed to create smaller, more manageable and more responsive private farms. The model is based on clear, transparent and stable land ownership or use rights, competitive input supply and marketing arrangements and devolution of social service functions from collective farm structures to local governments. In Belarus, continuing state support for large collective farms reflects a belief in economies of scale and highly mechanized farming, while collective farms also continue to be the main conduit for services and goods to the rural population. Only housing has been privatized to a great extent, while only kindergartens, libraries and halls have begun to be transferred to local governments.

146. More generally, the agriculture sector in Belarus continues to be characterized by pervasive government involvement and control. This includes district and regional production targets, fixed-price procurement quotas, indicative prices, profit margin

than collectives; ensuring transferability of land use rights; deep internal restructuring of the operations of state and collective farms; and coherent settlement of debts of farm enterprises.

${ }^{46}$ Plots of land immediately adjacent to private houses may also be privately owned. 
restrictions, and extensive trade restrictions and licensing requirements. All farm enterprises are subject to obligatory deliveries to state procurement agencies, and procurement quotas cover all major crop and livestock products. Officials of the Ministry of Agriculture concede that for some commodities, pure commercial sales simply "may not take place," due to pressures to fulfill production quotas.

147. Publicly-owned farm enterprises surveyed by the World Bank sell nearly 85 percent of their output to state procurement channels or to the processing industry, while private farms sell nearly two-thirds. Even individuals working household plots sell 20 percent of their output directly to state purchasers or processors and another 35 percent to local collective farms. State agencies supply nearly all fertilizer, farm machinery, construction materials and fuel, although private parties are emerging as suppliers of herbicides and pesticides, spare parts and veterinary drugs. ${ }^{47}$

148. The country's leadership recognizes the need for farm reorganization, given declining sectoral output and financial weaknesses, as well as the inability of the state budget and central bank to continue to provide the scale of support extended in recent years. Current proposais envisage that approximately $20-25$ percent of the farms will remain as is, while new management will be sought for a middle group of 50-60 percent of the farms. The remaining farms would be placed in bankruptcy and either merged with other profitable farms, input suppliers or processors or broken up.

\section{B. Land Reform and the Development of Private Farming}

149. Land reform in Belarus was undertaken mostly during 1990-92 and led to the transfer of nearly 16 percent of agricultural land to household plots and to individual private farms under leases. Household plots make up the bulk of the non-state land under cultivation, producing almost 40 percent of Belarus' gross agricultural product on just $151 / 2$ percent of the land.

150. The level of land use by private parties in Belarus is equivalent to the average for CIS countries and that in Russia and Ukraine. ${ }^{48}$ Still, the World Bank considers that Belarus stands out as the only country in central and eastern Europe and the CIS that (i) recognizes only very limited private ownership of land (household plots only); (ii) has no strategy for the allocation of the bulk of farmland to individuals or legal entities, either via sales, restitution or distribution to ex-collective farm members; and (iii) has a total prohibition of

${ }^{47}$ World Bank report, p. 83.

${ }^{48}$ In neighboring Lithuania, by comparison, farming by individuals increased from 8.3 percent of total crop area in 1990 to 65.9 percent in 1995 and 80.8 percent in 1998. Statistical Yearbook of Lithuania 1999 (p. 377). 
transferring of use rights. ${ }^{49}$ All other countries of the region meet at least one of these three criteria.

151. A new Land Code, adopted in 1999, allows for the increase of the size of household plots under private ownership from 0.5 hectares to up to one hectare and for private ownership of up to 0.25 hectares of agricultural land under and around a private house. Privatized land must be used for its initial purpose after privatization, and the right to own land extends only to Belarusian citizens. Land restitution has not taken place. Owners of household plots may lease an additional two hectares of land for subsistence farming, while private farmers may now lease up to 100 hectares of land, an increase from 50 hectares under the 1990 Land Code.

152. In spite of the decade-long right of private land ownership via household plots, the World Bank has estimated that just 3 percent of the land in household plots is formally privately owned in practice. Just 11 percent of respondents to a Bank survey reported that they have some form of official documentation certifying their rights under any form of possession or use. ${ }^{50}$

153. The new civil code allows for subleasing of land and mortgaging of land held by leaseholders in use rights. According to officials of the state Land Committee, loans may not be granted against privately-owned land, but beginning in mid-2000, loans may be granted against land leases according to presidential decree. The new land and civil codes provide for termination of land-use rights by local governments in cases of poor crop yields - which may be beyond the control of producers-while local authorities also have the right to dictate cropping patterns to land users.

154. Private farming by individual family farms has been slow to develop in Belarus. There are less than 3,000 independent family farms in the country, and this figure has declined by 15 percent since $1995 .^{51}$ These farms average some 25 hectares in size and constitute just 0.6 percent of agricultural land. ${ }^{52}$ The private farms are comprised of land

${ }^{49}$ The prohibition of transferring of use rights appears to have been eased, at least in principle, by the new civil code, which came into force in July 1999.

so World Bank report, p. 43.

${ }^{51}$ By comparison, as of July 1, 2000, there were nearly seventy thousand private farmers registered in neighboring Lithuania, which has one-third of Belarus' population and a similar proportion of rural dwellers. Source: Economic and Social Development in Lithuania, January-June 2000 (p. 59).

52 By contrast, the 2,500 state and collective farm enterprises average more than 3,000 hectares and employ more than 300 workers per farm. 
leased from state reserves, which were formed in 1991 from 10 percent of the land farmed (on an ongoing basis) by the collective farms, approximately one million hectares of arable land. With the new 1999 Land Code, private farmers may now lease up to 100 hectares from the state land reserves; more land may be subleased from collective farms, with the approval of the local administrations. Under the new civil code, land leases may be transferred or sold, and leasing of land is possible by Belarusian or foreign legal entities or physical persons.

155. Belarusian officials regard the small number of private farmers and the few applications for leasing of land as sign that there is little interest among the rural population in becoming private farmers. On the other hand, the authorities concede that the state reserve land in most cases is not the best land. A World Bank survey confirmed ambivalence among employees of collective farms concerning becoming private, independent farmers. Over 90 percent of farm employees surveyed by the Bank indicated that they have no intention of becoming private farmers, citing concerns about risk or personal health (old age) and shortage of funds. Yet, in spite of the cautiousness of collective farm members, the Bank's survey found that 60 percent of private farmers reported incomes above the subsistence level and an increasing standard of living with a much higher proportion of ownership of personal automobiles and household electronics and durable. ${ }^{53}$

\section{Conclusion}

156. During the past decade, agricultural reform in Belarus has focused on marginal improvement of the current system, with no major efforts made to move toward a marketbased system centered on private ownership. The collective farm system continues to be the dominant institutional structure in the sector, together with tight controls over trade and prices. The state has provided very substantial subsidies to the agriculture sector, and poor performance has been exacerbated by poor weather conditions in recent years. The authorities appear to be aware of worsening conditions and the inability to continue providing large-scale support, but proposals for changes are not yet ambitious or far reaching.

${ }^{53}$ World Bank report, pp. 93-97. 


\section{EXChaNGE SYSTEM}

157. The monetary guidelines for 2000 stipulate a move toward exchange rate unification and removal of exchange restrictions. The NBB has pursued this goal with an accelerated depreciation of the official exchange rate, from $\mathrm{Rbl} 320$ to the dollar at the beginning of the year to around $\mathrm{Rbl} 645$ to the dollar at the end of June. The exchange rates in the parallel market segments have remained relatively stable in nominal terms during this period, depreciating from around Rbl 945 to around Rbl 980 to the dollar.

158. The four main parallel rates have converged to within five percent of each other and appreciated in real terms during the first half of 2000 . This reflected tighter monetary policy, the accelerated depreciation of the official rate, and the shift from the black market to the exchange bureaus in the wake of a number of liberalization measures. Key developments in the main five market segments are summarized below.

159. The official exchange rate remains the basis for accounting and is determined during the first session of the Belarus Currency and Stock Exchange (BCSE), where surrendered export proceeds are channeled to priority importers.

160. The 30 percent surrender requirement on foreign exchange income from exports remains in place. A temporary 10 percent surrender surcharge imposed in March 2000 to finance oil imports expired after two months. Numerous exemptions to the surrender requirement imply that only about 14-15 percent of export proceeds are effectively surrendered. This amounted to around $\$ 50$ million per month in mid-2000.

161. The NBB distributes the full amount of the foreign exchange proceeds surrendered by exporters to priority importers during the morning session, according to percentage quotas set by the Council of Ministers. Of the dollars surrendered, 59 percent are allocated to oil, gas and coal imports, 11 percent to agro-industrial companies and 6 percent to medical goods importers, while the Ministry of Finance receives 7 percent for the service of sovereign guaranteed loans. Similar percentage quotas apply to Russian rubles and other major currencies.

162. The surrender requirement does not apply to exports to CIS countries other than Russia, nor does it apply to barter exports. Due to this inconsistency, a 15 percent barter fee was introduced in June 1999, although numerous exemptions apply to this fee. The fee was suspended in August 2000 by presidential decree.

163. The additional trading session at the BCSE was fully liberalized in March, 2000, when the NBB allowed banks to buy foreign exchange. The turnover during the first five months of this year was $\$ 72.6$ million compared to $\$ 6.3$ million during the same period in 1999. Since February 15, the difference between official rate and the rate on the additional session is no longer taxable. However, buyers of foreign exchange at the additional session are still disadvantaged as they have to account purchases of foreign exchange at the official 
rate and cannot record the difference between the official and actual rate as a cost item for tax purposes.

164. The cash market was liberalized in December 1999, allowing exchange bureaus to set rates freely. This led to a significant increase in turnover in exchange bureaus and eliminated most of the black market (although not fully, given the requirement to present a passport and given the daily limit of exchanging $\$ 300$ per person per exchange bureau). Exchange bureaus are no longer required to sell their surplus foreign exchange at the official exchange rate. As of mid-2000, some 1,600 exchange bureaus operated in the country.

165. The interbank market was liberalized after restrictions on volumes were removed in December 1999. The differential between the official exchange rate and the interbank rate is still taxable, although this is expected to change soon, in addition to changes in accounting rules to prepare for the revaluation implied by exchange rate unification. During the first five months of 2000 , the turnover on the interbank market was $\$ 159.4$ million, compared to $\$ 113.6$ million in the same period a year earlier.

166. The non-resident markets (mainly in Russia and the Baltic states) remain affected by restrictive measures, although these bave been partly lifted. At the end of 1999, the use of Belarusian rubels was allowed for invoicing of exports. Payments for imports in rubels still require a permit by the $\mathrm{NBB}$, although the group of goods for which this permit is granted has been widened and medical goods were exempted from the restriction in May 2000 . As a result of the liberalization of rubel payments for exports and the persistence of restrictions on rubel payments for imports, the Belarusian rubel has strengthened on the non-resident markets and the NBB has intervened as a buyer of foreign exchange on this segment. The non-resident market accounts for 5-10 percent of the total foreign exchange turnover.

167. The NBB has plans to unify the exchange rate by the end of the third quarter of 2000 . However, there is not yet agreement within the government on this timetable and the possible complementary policy measures, even if there is little opposition to the principle of unification. A number of governmental task forces have been set up to analyze the ramifications of unification and work on various implementation issues.

168. According to the NBB, the unification of the exchange rates should go hand in hand with further liberalization of the foreign exchange market. Specifically, it plans to merge the morning session of the BCSE with the additional session. ${ }^{54}$ The NBB also plans to reduce the 30 percent export surrender requirement, possibly to 20 percent, but not to eliminate it in the near term. Finally, restrictions on payments of imports in Belarusian rubels should be eased, although it is not clear when they would be eliminated. ${ }^{55}$

\footnotetext{
${ }^{54}$ This was done in mid-September 2000.

${ }^{55}$ This restriction was lifted in mid-September 2000 .
} 
Table 1. Belarus: Gross Domestic Product by Sector, 1995-99 1/

\begin{tabular}{|c|c|c|c|c|c|}
\hline & 1995 & 1996 & 1997 & 1998 & 1999 \\
\hline & \multicolumn{5}{|c|}{ (In millions of rubels) } \\
\hline GDP at market prices & 119,813 & 184,174 & 356,079 & 675,159 & $2,890,320$ \\
\hline GDP at factor cost & 108,037 & 163,351 & 309,325 & 583,523 & $2,495,047$ \\
\hline Industry & 33,922 & 56,519 & 110,727 & 200,680 & 855,049 \\
\hline Agriculture and forestry & 19,104 & 26,074 & 45,537 & 79,459 & 322,299 \\
\hline Construction & 6,563 & 8,943 & 20,275 & 40,922 & 178,767 \\
\hline Transportion/communications & 14,867 & 21,046 & 37,546 & 69,474 & 298,048 \\
\hline Trade and catering & 9,191 & 14,336 & 26,401 & 60,164 & 285,976 \\
\hline Material supply and procurement & 3,714 & 2,766 & 5,422 & 10,423 & 43,718 \\
\hline Housing and pubiic utilities & 4,701 & 7,208 & 13,723 & 25,230 & 93,069 \\
\hline Health care & 3,584 & 5,695 & 11,523 & 21,678 & 96,401 \\
\hline Education, cuiture, and science & 5,708 & 9,909 & 18,840 & 37,642 & 156,655 \\
\hline \multirow[t]{2}{*}{ Other } & 6,684 & 10,855 & 19,332 & 37,850 & 165,065 \\
\hline & \multicolumn{5}{|c|}{ (In percent of nominal GDP at factor cost) } \\
\hline Industry & 31.4 & 34.6 & 35.8 & 34.4 & 34.3 \\
\hline Agriculture and forestzy & 17.7 & 16.0 & 14.7 & 13.6 & 12.9 \\
\hline Construction & 6.1 & 5.5 & 6.6 & 7.0 & 7.2 \\
\hline Transportion/communications & 13.8 & 12.9 & 12.1 & 11.9 & 11.9 \\
\hline Trade and catering & 8.5 & 8.8 & 8.5 & 10.3 & 11.5 \\
\hline Materiai supply and procurement & 3.4 & 1.7 & 1.8 & 1.8 & 1.8 \\
\hline Housing and public utilities & 4.4 & 4.4 & 4.4 & 4.3 & 3.7 \\
\hline Health care & 3.3 & 3.5 & 3.7 & 3.7 & 3.9 \\
\hline Education, culture and science & 5.3 & 6.1 & 6.1 & 6.5 & 6.3 \\
\hline Other & 6.1 & 6.6 & 6.2 & 6.5 & 6.6 \\
\hline Total & 100.0 & 100.0 & 100.0 & 100.0 & 100.0 \\
\hline
\end{tabular}

Sources: Ministry of Statistics and Analysis; and Fund staff estimates.

1/ Data have been revised backward to reflect the redenomination of the rubel on January 1,2000 which removed three zeros from the currency. 
Table 2. Belarus: Gross Domestic Product by Expenditure, 1995-99

(At current prices)

\begin{tabular}{|c|c|c|c|c|c|}
\hline & 1995 & 1996 & 1997 & 1998 & 1999 \\
\hline & \multicolumn{5}{|c|}{ (In millions of rubels) } \\
\hline GDP at market prices & 119,813 & 184,174 & 356,079 & 675,159 & $2,890,320$ \\
\hline Consumption of goods and services & 95,513 & 146,230 & 275,316 & 538,987 & $2,267,664$ \\
\hline Household consumption & 68,635 & 104,226 & 193,708 & 382,914 & $1,616,780$ \\
\hline Public consumption & 26,877 & 42,004 & 81,608 & 156,072 & 650,884 \\
\hline General government & 23,157 & 36,627 & 72,441 & 139,143 & 581,868 \\
\hline Public organizations & 3,721 & 5,377 & 9,167 & 16,930 & 69,016 \\
\hline Gross capital formation & 30,047 & 45,119 & 98,446 & 187,561 & 692,883 \\
\hline Gross fixed capital formation $1 /$ & 29,984 & 40,938 & 92,555 & 182,103 & 740,550 \\
\hline Changes in irventories & 63 & 4,631 & $5,89 \downarrow$ & 5,458 & $-47,667$ \\
\hline Trade balance $2 /$ & $-5,747$ & $-7,174$ & $-22,401$ & $-34,024$ & $-82,829$ \\
\hline \multirow[t]{2}{*}{ Statistical discrepancy } & 0 & 0 & 4,718 & $-17,365$ & 12,604 \\
\hline & \multicolumn{5}{|c|}{ (In percent of nominal GDP at market prices) } \\
\hline Consumption of goods and services & 79.7 & 79.4 & 77.3 & 79.8 & 78.5 \\
\hline Household consumption & 57.3 & 56.6 & 54.4 & 56.7 & 56.0 \\
\hline Public consumption & 22.4 & 22.8 & 22.9 & 23.1 & 22.5 \\
\hline General government & 19.3 & 19.9 & 20.3 & 20.6 & 20.1 \\
\hline Public organizations & 3.1 & 2.9 & 2.6 & 2.5 & 2.4 \\
\hline Gross capital formation & 25.1 & 24.5 & 27.7 & 27.8 & 24.0 \\
\hline Gross fixed capital formation $1 /$ & 25.0 & 22.0 & 26.0 & 27.0 & 25.6 \\
\hline Changes in inventories & 0.1 & 2.5 & 1.7 & 0.8 & -1.6 \\
\hline Trade balance $2 /$ & -4.8 & -3.9 & -6.3 & -5.0 & -2.9 \\
\hline Statistical discrepancy & 0.0 & 0.0 & 1.3 & -2.6 & 0.4 \\
\hline
\end{tabular}

Sources: Ministry of Statistics and Analysis; and Fund staff estimates.

1/ Includes residential investment.

2/ Provisional data, not fully consistent with recently revised balance of payments data (Table 43). 
Table 3. Belarus: Growth of Gross Domestic Product by Expenditure, 1995-99

(Index, 1995=100)

\begin{tabular}{|c|c|c|c|c|c|}
\hline & 1995 & 1996 & 1997 & 1998 & 1999 \\
\hline & \multicolumn{5}{|c|}{ (Percentage change) } \\
\hline Gross domestic product & -10.4 & 2.8 & 11.4 & 8.4 & 3.4 \\
\hline Total consumption of goocis and services & -9.5 & 3.2 & 9.5 & 10 & 4.2 \\
\hline Household consumption & -12.3 & 4.5 & $10.0^{\circ}$ & 11.8 & 5.0 \\
\hline Public consumption & $\ldots$ & 0.0 & 8.4 & 5.7 & 2.1 \\
\hline General government & -2.9 & -0.2 & 8.9 & 6.1 & 2.0 \\
\hline Consumption of public organizations & -0.6 & 1.1 & 5.1 & 2.3 & 2.4 \\
\hline Gross capital formation & -28.7 & 7.2 & 15.9 & 6.9 & -13.7 \\
\hline Gross fixed capital formation $1 /$ & -29.6 & -3.1 & 21.7 & 10.1 & -5.4 \\
\hline Changes in inventories & 0.9 & 10.3 & -5.8 & -3.2 & -8.3 \\
\hline Balance of exports and imports & 145.2 & 24.8 & 212.2 & $\$ 1.9$ & 143.4 \\
\hline \multirow[t]{2}{*}{ Statistical discrepancy } & $\cdots$ & $\ldots$ & $\cdots$ & 60.0 & $\cdots$ \\
\hline & \multicolumn{5}{|c|}{ (Contribution to growth) } \\
\hline Total consumption of goods and services & -7.6 & 2.5 & 7.3 & 8.0 & 3.3 \\
\hline Household consumption & -7.0 & 2.5 & 5.4 & 6.7 & 2.8 \\
\hline Public consumption & 0.0 & 0.0 & 1.9 & 1.3 & 0.5 \\
\hline General government & -0.6 & 0.0 & 1.8 & 1.3 & 0.4 \\
\hline Consumption of public organizations & 0.0 & 0.0 & 0.1 & 0.1 & 0.1 \\
\hline Gross capital formation & -7.2 & 1.8 & 4.4 & 1.9 & -3.3 \\
\hline Gross fixed capital formation $1 /$ & -7.4 & -0.7 & 5.6 & 2.7 & -1.4 \\
\hline Changes in inventories & 0.0 & 0.3 & -0.1 & 0.0 & 0.1 \\
\hline Balance of exports and imports 2 & 0.81 & 0.02 & 0.12 & 0.01 & 0.02 \\
\hline Statistical discrepancy & $\ldots$ & $\ldots$ & $\ldots$ & 1.0 & $\ldots$ \\
\hline
\end{tabular}

Sources: Ministry of Statistics and Analysis; and Fund staff estimates.

1/ Includes residential investment.

2/ Provisional data, not fully consistent with recently revised balance of payments data (Table 43). 
Table 4. Belarus: Growth of Gross Domestic Product by Sector, 1995-99

(At comparable prices) $1 /$

\begin{tabular}{|c|c|c|c|c|c|}
\hline & 1995 & 1996 & 1997 & 1998 & 1999 \\
\hline & \multicolumn{5}{|c|}{ (Percentage change) } \\
\hline GDP at market prices & -10.4 & 28 & 11.4 & 8.4 & 3.4 \\
\hline Industry & -10.2 & 4.1 & 16.5 & 8.7 & 8.3 \\
\hline Agriculture & -2.5 & 1.4 & -5.9 & -0.9 & -9.1 \\
\hline Forestry & -5.1 & 2.1 & -9.4 & 13.9 & -20.0 \\
\hline Construction & -33.2 & -7.6 & 21.4 & 14.2 & -0.2 \\
\hline Transport & -9.4 & -2.1 & 5.2 & 3.5 & 3.2 \\
\hline Communications & -13.3 & -1.0 & 13.6 & 4.6 & 5.7 \\
\hline Trade and catering & -24.0 & 21.2 & 18.4 & 26.2 & 9.1 \\
\hline Material supply and procurement & -22.7 & -1.3 & 4.3 & -0.3 & -11.5 \\
\hline Housing & -0.3 & 0.6 & 1.3 & 2.9 & 1.4 \\
\hline Public utilities & -5.6 & -3.7 & -1.3 & -2.3 & -0.5 \\
\hline Health care & -0.6 & 1.8 & 14.2 & 7.2 & 1.9 \\
\hline Education & -1.5 & 2.8 & 14.7 & 5.9 & 5.2 \\
\hline Culture and science & -9.2 & 1.8 & -3.5 & 3.0 & -0.4 \\
\hline Barks and insurance & 17.0 & 2.0 & 1.9 & 6.1 & 3.3 \\
\hline \multirow[t]{2}{*}{ Public administration and deferise } & -2.0 & -0.8 & 6.7 & 3.6 & 0.9 \\
\hline & \multicolumn{5}{|c|}{ (Contribution to growth) } \\
\hline Industry & -3.2 & 1.4 & 5.9 & 3.0 & 2.8 \\
\hline Agriculture & -0.4 & 0.2 & -0.8 & -0.1 & -1.1 \\
\hline Construction & -2.0 & -0.4 & 1.4 & 1.0 & 0.0 \\
\hline Transport & -1.1 & -0.2 & 0.5 & 0.4 & 0.3 \\
\hline Trade and catering & -2.0 & 1.9 & 1.6 & 2.7 & 1.0 \\
\hline
\end{tabular}

Sources: Ministry of Statistics and Analysis; and Fund staff estimates.

1/ The use of comparable prices denotes the comparison of output of the current period with output for the previous period based on prices for the previous period. 
Table 5. Belarus: Capital Investment by Sector in Comparable Prices, 1995-99 1/ (In comparable prices)

\begin{tabular}{|c|c|c|c|c|c|}
\hline & 1995 & 1996 & 1997 & 1998 & 1999 \\
\hline & \multicolumn{5}{|c|}{ (Index, 1990=100) } \\
\hline Total & 39.2 & 37.3 & 44.6 & 55.6 & 45.2 \\
\hline Industry & 47.7 & 47.7 & 56.6 & 79.7 & 50.8 \\
\hline Agriculture & 11.6 & 9.8 & 9.8 & 13.2 & 9.6 \\
\hline Transport and communication & 85.1 & 99.6 & 108.6 & 98.9 & 97.7 \\
\hline Construction & 21.6 & 14.6 & 17.9 & 25.6 & 14.2 \\
\hline Residential construction & 40.0 & 38.1 & 54.0 & 68.3 & 63.9 \\
\hline \multirow[t]{2}{*}{ Other } & 56.4 & 45.6 & 53.3 & 65.2 & 59.3 \\
\hline & & \multicolumn{4}{|c|}{ (Share of total) } \\
\hline Industry & 29.7 & 31.2 & 30.9 & 35.0 & 27.4 \\
\hline Agriculture & 8.5 & 7.5 & 6.4 & 6.6 & 6.1 \\
\hline Transport and communication & 16.0 & 19.7 & 17.9 & 12.9 & 15.9 \\
\hline Construction & 1.7 & 1.2 & 1.3 & 1.9 & 1.0 \\
\hline Residential construction & 20.0 & 20.1 & 23.7 & 23.3 & 27.8 \\
\hline Other & 24.1 & 20.3 & 19.8 & 20.3 & 21.8 \\
\hline \multicolumn{6}{|l|}{ Of which } \\
\hline Trade and catering & 1.6 & 2.0 & 2.0 & 3.7 & 1.7 \\
\hline Total & 100.0 & 100.0 & 100.0 & 100.0 & 100.0 \\
\hline \multicolumn{6}{|l|}{ Memorandum items: } \\
\hline Real gross investment (Index, 1991=100) 2 & 45.6 & 48.9 & 56.7 & 60.6 & 52.3 \\
\hline $\begin{array}{l}\text { Gross investment } \\
\text { (in percent of GDP) } 2 /\end{array}$ & 25.1 & 24.5 & 27.7 & 27.8 & 24.0 \\
\hline
\end{tabular}

Sources: Ministry of Statistics and Analysis; and Fund staff estimates.

1/ Some figures may be inconsistent with the national accounts tables, as the data are based on surveys of industrial projects by branches of the economy.

2/ According to national accounts data. 
Table 6. Belanus: Industrial Production, 1996-2000 (Q1)

\begin{tabular}{|c|c|c|c|c|c|}
\hline & 1996 & 1997 & 1998 & 1999 & $2000 \quad 1 /$ \\
\hline & \multicolumn{5}{|c|}{ (Percentage change in comparable prices) } \\
\hline Total & 3.5 & 18.8 & 12.4 & 10.3 & 7.5 \\
\hline \multicolumn{6}{|l|}{ Of which: } \\
\hline Power generation & -1.6 & 5.6 & -7.4 & 5.4 & 2.4 \\
\hline Refineries & -5.5 & -1.0 & 0.7 & 1.9 & 9.8 \\
\hline Chemicals and petrochemicals & 7.2 & 19.4 & 7.7 & 7.0 & 8.8 \\
\hline Ferrous metallurgy & 23.4 & 35.1 & 14.9 & 0.0 & 6.1 \\
\hline Machine building & 1.6 & 25.7 & 15.5 & 16.2 & 8.3 \\
\hline Wood and paper & 14.2 & 34.7 & 21.7 & 16.0 & 12.9 \\
\hline Construction materials & -4.0 & 26.1 & 15.2 & 1.5 & -5.8 \\
\hline Light industry & 11.9 & 27.1 & 22.8 & 10.8 & 9.8 \\
\hline Food-processing industries & 5.5 & 21.0 & 19.2 & 14.4 & 7.7 \\
\hline
\end{tabular}

Sources: Ministry of Statistics and Analysis; and Fund staff estimates.

1/ Compared to the first quarter of 1999. 
Table 7. Belarus: Inventories of Final Products in the Warehouses of Industrial Enterprises by Subsector, 1996-2000 (Q1) 1/2/

1996

1997

1998

1999 $\frac{2000}{\mathrm{Q1}}$

(In millions of rubels)

\begin{tabular}{|c|c|c|c|c|c|}
\hline Total & 9,514 & 16,453 & 46,971 & 135,733 & 223,607 \\
\hline \multicolumn{6}{|l|}{ Of which: } \\
\hline Fuel & 76 & 164 & 1,376 & 5,755 & 8,775 \\
\hline Ferrous metalhurgy & 66 & 199 & 1,354 & 1,920 & 3,013 \\
\hline Nonferrous metallurgy & 10 & $\ldots$ & 90 & 86 & 113 \\
\hline Chemicals and petrochemicals & 1,063 & 2,065 & 8,318 & 18,520 & 21,732 \\
\hline Machine building and metal-working & 5,446 & 9,180 & 20,896 & 59,580 & 98,658 \\
\hline Forestry, wood, and paper products & 451 & 646 & 2,655 & 7,743 & 17,241 \\
\hline Construction materials industry & 329 & 553 & 1,238 & 4,023 & 6,530 \\
\hline Light industry & 783 & 1,361 & 5,952 & 17,460 & 30,877 \\
\hline \multirow[t]{2}{*}{ Food processing industries } & 739 & 1,449 & 3,498 & 14,911 & 27,263 \\
\hline & \multicolumn{5}{|c|}{ (As a percent of current month's output) } \\
\hline Total & 52.2 & 38.0 & 85.9 & 54.7 & 52.3 \\
\hline \multicolumn{6}{|l|}{ Of which: } \\
\hline Fuel & 12.6 & 13.2 & 63.0 & 56.4 & 37.8 \\
\hline Ferrous metallurgy & 13.5 & 16.6 & 67.7 & 23.5 & 21.0 \\
\hline Nonferrous metallurgy & $\cdots$ & $\cdots$ & 160.5 & 40.2 & 36.8 \\
\hline Chemicals and petrochemicals & 51.7 & 43.2 & 103.2 & 47.6 & 35.2 \\
\hline Machine building and metal-working & 138.6 & 106.1 & 145.7 & 93.9 & 93.6 \\
\hline Forestry, wood, and paper products & 52.3 & 34.3 & 79.9 & 51.4 & 64.9 \\
\hline Construction materials industry & 58.6 & 47.9 & 59.4 & 44.7 & 53.8 \\
\hline Light industry & 47.5 & 38.4 & 110.8 & 71.5 & 65.2 \\
\hline Food-processing industries & 26.5 & 23.2 & 36.6 & 34.9 & 35.9 \\
\hline
\end{tabular}

Sources: Ministry of Statistics and Analysis; and Fund staff estimates.

$1 /$ End-of-period stocks.

2/ Data have been revised backward to reflect the redenomination of the rubel on January 1,2000 which removed three zeros from the currency. 
Table 8. Belarus: Agricultural Production, 1995-99

\begin{tabular}{|c|c|c|c|c|c|}
\hline & 1995 & 1996 & 1997 & 1998 & 1999 \\
\hline & \multicolumn{5}{|c|}{ (In thousands of metric tons, uniess otherwise indicated) } \\
\hline Grain & 5,502 & 5,792 & 6,420 & 4,831 & 3645 \\
\hline Potatoes & 9,504 & 10,881 & 6,942 & 7,574 & 7491 \\
\hline Flax & 60 & 49 & 26 & 36 & 21 \\
\hline Sugar beets & 1,172 & 1,011 & 1,262 & 1,428 & 1186 \\
\hline Meat & 995 & 937 & 941 & 981 & 949 \\
\hline Milk & 5,070 & 4,908 & 5,133 & 5,232 & 4741 \\
\hline Eggs & 3,373 & 3,403 & 3,459 & 3,481 & 3395 \\
\hline \multicolumn{6}{|c|}{ Live animals ( 1,000 head) $1 /$} \\
\hline Cattle & 5,054 & 4,855 & 4,802 & 4,686 & 4326 \\
\hline Pigs & 3,895 & 3,715 & 3,686 & 3,698 & 3566 \\
\hline Sheep & 204 & 155 & 127 & 106 & 92 \\
\hline \multirow[t]{2}{*}{ Horses } & 229 & 232 & 233 & 229 & 221 \\
\hline & \multicolumn{5}{|c|}{ (Percentage change from previous year) } \\
\hline Grain & -9.7 & 5.3 & 10.8 & -24.8 & -24.5 \\
\hline Potatoes & 15.3 & 14.5 & -36.2 & 9.1 & -1.1 \\
\hline Flax & 22.4 & -18.3 & -46.9 & 38.5 & -41.7 \\
\hline Sugar beets & 8.7 & -13.7 & 24.8 & 13.1 & -16.9 \\
\hline Meat & -12.6 & -5.8 & 0.4 & 4.2 & -3.2 \\
\hline Milk & -8.0 & -3.2 & 4.6 & 1.9 & -9.4 \\
\hline Eggs & -0.8 & 0.9 & 1.7 & 0.6 & -2.5 \\
\hline \multicolumn{6}{|l|}{ Livestock $1 /$} \\
\hline Cattle & -6.5 & -3.9 & -1.1 & -2.4 & -7.7 \\
\hline Pigs & -2.7 & -4.6 & -0.8 & 0.3 & -3.6 \\
\hline Sheep & -11.3 & -23.7 & -18.1 & -16.7 & -13.4 \\
\hline \multirow[t]{2}{*}{ Horses } & 4.1 & 1.3 & 0.7 & -1.9 & -3.2 \\
\hline & \multicolumn{5}{|c|}{ (Yield per hectare) } \\
\hline Grain & 20.4 & 21.7 & 23.6 & 18.3 & 14.5 \\
\hline Potatoes & 131.0 & 151.0 & 99.0 & 109.0 & 113 \\
\hline Flax & 6.1 & 6.2 & 3.6 & 4.8 & 2.7 \\
\hline Sugar beets & 212.0 & 223.0 & 267.0 & 278.0 & 217.0 \\
\hline
\end{tabular}

Sources: Ministry of Statistics and Analysis; and Fund staff estimates.

1/ End-of-period stocks. 
Table 9. Belarus: Production and Consumption of Energy, 1995-99

\begin{tabular}{|c|c|c|c|c|c|}
\hline & 1995 & 1996 & 1997 & 1998 & 1999 \\
\hline \multicolumn{6}{|l|}{ Production } \\
\hline Electricity (million kwh) & 24,918 & 23,728 & 26,057 & 23,492 & 26,516 \\
\hline Natural gas (million cubic meters) & 266 & 249 & 246 & 252 & 256 \\
\hline Crude oil (thousand tons) & 1,932 & 1,860 & 1,822 & 1,830 & 1,840 \\
\hline Gasoline (thousand tons) & 1,849 & 1,816 & 1,954 & 1,907 & 1,685 \\
\hline Diesel (thousand tons) & 3,465 & 3,170 & 3,115 & 3,318 & 3,398 \\
\hline Heavy fuel oil (thousand tons) & 5,592 & 4,812 & 4,524 & 4,253 & 4,305 \\
\hline \multicolumn{6}{|l|}{ Imports } \\
\hline Electricity (million kwh) & 7 & 9 & 10,308 & 12,747 & 10,192 \\
\hline Natural gas (million cubic meters) & 14 & 14 & 16,241 & 16,004 & 16,565 \\
\hline Crude oil (thousand tons) & 12 & 11 & 10,461 & $10,05,5$ & 9,900 \\
\hline Gasoline (thousand tons) & 53 & 72 & 56 & 21 & 55 \\
\hline Diesel (thousand tons) & 24 & 18 & 33 & 83 & 90 \\
\hline Heavy fuel oil (thousand tons) & 36 & 16 & 27 & 42 & 343 \\
\hline \multicolumn{6}{|l|}{ Exports } \\
\hline Electricity (million kwh) & 2,907 & 2,601 & 2,688 & 2,073 & 3,029 \\
\hline Crude oil (thousand tons) & 200 & 300 & 400 & 382 & 300 \\
\hline Gasoline (thousand tons) & 551 & 683 & 666 & 688 & 624 \\
\hline Diesel (thousand tons) & 1,711 & 1,470 & 990 & 1,609 & 1,761 \\
\hline Heavy fuel oil (thousand tons) & 233 & 901 & 713 & 887 & 2,332 \\
\hline \multicolumn{6}{|l|}{ Change in stocks } \\
\hline Natural gas (million cubic meters) & 43 & -7 & 110 & 22 & 6 \\
\hline Crude oil (thousand tons) & -25 & 250 & -95 & -47 & 48 \\
\hline Gasoline (thousand tons) & -82 & 100 & -97 & 33 & 11 \\
\hline Diesel (thousand tons) & 27 & 182 & -242 & 163 & 96 \\
\hline Heavy fuel oil (thousand tons) & .217 & 189 & -133 & -4 & 531 \\
\hline \multicolumn{6}{|l|}{ Consumption } \\
\hline Electricity (million kwh) & 22,018 & 21,136 & 33,677 & 34,166 & 33,680 \\
\hline \multicolumn{6}{|l|}{ Of which: } \\
\hline Industrial sector (million kwh) & 13,383 & 13,456 & 15,321 & 15,714 & 15,668 \\
\hline Natural gas (million cubie meters) & 13,840 & 14,587 & 16,597 & 16,278 & 16,827 \\
\hline \multicolumn{6}{|l|}{ Of which: } \\
\hline $\begin{array}{l}\text { For production of heating and } \\
\text { electricity (million meters) }\end{array}$ & 9,903 & 10,748 & 12,449 & 11,422 & 12,096 \\
\hline Crude oil (thousand tons) & 1,719 & 1,821 & 11,788 & 11,456 & 11,488 \\
\hline Gasoline (thousand tons) & 1,269 & 1,305 & 1,247 & 1,273 & 1,127 \\
\hline Diesel (thousand tons) & 1,805 & 1,900 & 1,916 & 1,955 & 1,823 \\
\hline Heavy fuel oil (thousand tons) & 5,178 & 4,711 & 3,705 & 3,404 & 2,847 \\
\hline \multicolumn{6}{|l|}{ Of which: } \\
\hline $\begin{array}{l}\text { For production of heating and } \\
\text { electricity (million meters) }\end{array}$ & 4,238 & 4,073 & 2,759 & 2,612 & 2,335 \\
\hline \multicolumn{6}{|l|}{ Losses in distribution } \\
\hline Electricity (million kwh) & 3,636 & 3,757 & 3,801 & 3,796 & 3,544 \\
\hline Natural gas (miilion cubic meters) & 139 & 155 & 135 & 133 & 103 \\
\hline
\end{tabular}

Sources: Ministry of Statistics and Analysis; and Fund staff estimates. 
Table 10. Belarus: Change in Consumer and Producer Prices 1996-2000 (June)

\begin{tabular}{|c|c|c|c|c|}
\hline & \multicolumn{2}{|c|}{ Consumer Prices: $\mathrm{CPI} 1 /$} & \multicolumn{2}{|c|}{ Producer Prices: EP: $\mathcal{Z}$} \\
\hline & $\begin{array}{l}\text { Monthly percentage } \\
\text { change }\end{array}$ & $\begin{array}{c}\text { Year-onl-year } \\
\text { petcentuge change }\end{array}$ & $\begin{array}{l}\text { Momthly percentage } \\
\text { ehange }\end{array}$ & $\begin{array}{c}\text { Year-on-year } \\
\text { percentage change }\end{array}$ \\
\hline \multicolumn{5}{|l|}{1996} \\
\hline Jamary & 5.6 & 161 & 3.8 & 59 \\
\hline Febniary & 4.0 & 103 & 0.6 & 45 \\
\hline Mareh & 2.0 & 73 & 1.3 & 38 \\
\hline Aprit & 1.5 & 53 & 1.7 & 34 \\
\hline May & 0.6 & 49 & 0.4 & 31 \\
\hline June & 2.3 & 49 & 2.3 & 32 \\
\hline July & 2.0 & 44 & 1.9 & 32 \\
\hline August & 1.3 & 42 & 3.8 & 31 \\
\hline Sep̧tember & 1.8 & 37 & $2 . I$ & 28 \\
\hline October & 1.3 & 34 & 1.5 & 26 \\
\hline November & 3.9 & 35 & 2.3 & 27 \\
\hline Decentiber & 7.4 & 39 & 6.0 & 31 \\
\hline \multicolumn{5}{|l|}{1997} \\
\hline January & 13.3 & 49 & 18.5 & 50 \\
\hline February & 6.6 & 53 & 14.3 & 70 \\
\hline March & 2.3 & 54 & 5.3 & 77 \\
\hline April & 4.3 & 58 & 6.8 & 86 \\
\hline May & 5.0 & 65 & 6.0 & 97 \\
\hline June & 4.5 & 68 & 3.1 & 98 \\
\hline July & 1.4 & 67 & 2.7 & 100 \\
\hline August & 1.0 & 67 & 1.4 & 95 \\
\hline September & 5.0 & 72 & 2.1 & 95 \\
\hline October & 3.2 & 75 & 2.2 & 96 \\
\hline November & 1.8 & 71 & 2.2 & 96 \\
\hline December & 2.3 & 63 & 2.3 & 89 \\
\hline \multicolumn{5}{|l|}{1998} \\
\hline Jamuary & 3.9 & 50 & 4.1 & 66 \\
\hline Febriary & $3 . j$ & 45 & 3.8 & 51 \\
\hline Manch & 3.3 & 46 & 3.0 & 48 \\
\hline Aprii & 3.8 & 45 & 2.5 & 42 \\
\hline May & 3.4 & 43 & 2.5 & 37 \\
\hline June & 2.7 & 41 & 3.4 & 37 \\
\hline July & 2.8 & 43 & 5.0 & 40 \\
\hline August & 3.8 & 47 & 6.3 & 47 \\
\hline September & 17.6 & 65 & 12.1 & 61 \\
\hline October & 21.0 & 93 & 16.0 & 83 \\
\hline November & 25.0 & 137 & 21.7 & 118 \\
\hline Decenber & 21.7 & 182 & 40.7 & 200 \\
\hline \multicolumn{5}{|l|}{1999} \\
\hline January & 16,6 & 216 & 29.1 & 272 \\
\hline February & 13.7 & 249 & 18.2 & 324 \\
\hline March & 12.1 & 279 & 15.0 & 374 \\
\hline April & 7.4 & 292 & 6.2 & 391 \\
\hline May & 8.9 & $3 / 2$ & 6.7 & 412 \\
\hline June & 7.1 & 330 & 5.1 & 420 \\
\hline July & 6.0 & 343 & 5.3 & 421 \\
\hline August & 7.1 & 357 & 7.8 & 429 \\
\hline Septenber & 12.1 & 336 & 7.5 & 407 \\
\hline October & 14.2 & 311 & 9.5 & 378 \\
\hline Nowember & 14.3 & 276 & 10.4 & 334 \\
\hline December & 13.6 & 251 & 11.9 & 245 \\
\hline \multicolumn{5}{|l|}{2000} \\
\hline January & 14.1 & 244 & 11.6 & 200 \\
\hline February & 9.3 & 230 & 10.3 & 180 \\
\hline March & 5.8 & 212 & 10.3 & 168 \\
\hline April & 5.1 & 205 & 6.4 & 169 \\
\hline May & 4.7 & 193 & 9.7 & 176 \\
\hline June & 6.1 & 191 & 10.2 & 190 \\
\hline \multicolumn{5}{|l|}{ Average } \\
\hline 1992 & 30.6 & 971 & 49.9 & 1,939 \\
\hline 1993 & 29.2 & 1,190 & 31.3 & 1,536 \\
\hline 1994 & 29.1 & 2,221 & 28.6 & 2,171 \\
\hline 1995 & 11.5 & 709 & 7.4 & 462 \\
\hline 1996 & 2.8 & 53 & 2.3 & 34 \\
\hline 1997 & 4.2 & 64 & 5.6 & 88 \\
\hline 1998 & 9.3 & 73 & 10.1 & 72 \\
\hline 1999 & 11.1 & 294 & 11.1 & 356 \\
\hline
\end{tabular}

Sources: Ministry of Statistics and Analysis; and Fund staff estimates.

1/ The Consumer Price Index (CPI) uses weights from the previous year's Household Expendinte Survey. 2/ Industrial Production Price Index (IPPI) data are based on a corrected index formula (Laspeyres) using the weights terived from the structure of output of products by branches of industry in 1993. 
Table 11. Belarus: Changes in Administered Prices of Household Services, 1999-2000 (June)

(Percentage change)

\begin{tabular}{|c|c|c|c|c|c|c|c|c|c|c|c|c|c|c|c|c|c|c|c|c|c|}
\hline & & & & \multicolumn{12}{|c|}{1999} & \multicolumn{6}{|c|}{2000} \\
\hline & $\begin{array}{l}\text { Dee } 97 / \\
\text { Dec } 96\end{array}$ & $\begin{array}{l}\text { Dec } 98 / \\
\text { Dec } 97\end{array}$ & $\begin{array}{l}\text { Dec } 99 / \\
\text { Dec } 98\end{array}$ & Jan & Feb & Mar & Apr & May & Jun & Jul & Aug & Sep & Oet & Nov & $\overline{\text { Dec }}$ & Jan & Feb & Mar & Apr & May & $\overline{\text { Jun }}$ \\
\hline \multicolumn{22}{|l|}{ Utilities } \\
\hline Rent & 20.0 & 20.0 & $\ldots$ & $\ldots$ & $\ldots$ & $\ldots$ & $\ldots$ & $\ldots$ & 60.0 & 4.7 & 5.2 & $\ldots$ & & & & 8.4 & 2.1 & 35.1 & $\$ 1.6$ & 30.0 & 10.9 \\
\hline Water & 58.7 & 662,7 & 36.3 & 25.0 & $\ldots$ & $\ldots$ & $\ldots$ & 70.0 & 4.9 & 4.7 & 5.2 & 5.4 & 6.7 & 8.2 & 7.7 & 8.6 & 1.9 & 11.7 & 11.7 & 5.9 & 10.9 \\
\hline Sewage & 58.7 & 534.4 & 36.3 & 25.0 & $\ldots$ & $\ldots$ & $\ldots$ & 45.0 & 4.9 & 4.7 & 5.2 & 5.4 & 6.7 & 8.2 & 7.7 & 8.6 & 1.9 & 11.7 & 11.7 & 5.9 & 10.9 \\
\hline Heating $1 /$ & 38.0 & $\ldots$ & $\ldots$ & $\ldots$ & $\cdots$ & $\ldots$ & $\ldots$ & $\ldots$ & 4.9 & 50.0 & 30.0 & $\ldots$ & 6.7 & 8.2 & 20.0 & 8.6 & 1.9 & 11.2 & 11.7 & 30.0 & 10.9 \\
\hline Hot water & 38.0 & $\ldots$ & $\ldots$ & $\ldots$ & $\ldots$ & $\ldots$ & $\ldots$ & $\ldots$ & 4.9 & 50.0 & 30.0 & 20.0 & 6.7 & 8.2 & 20.0 & 8.6 & 1.9 & 11.8 & 11.7 & 30.0 & 10.9 \\
\hline \multicolumn{22}{|l|}{ Electricity } \\
\hline City dwellers & 33.0 & 88.3 & $\ldots$ & $\ldots$ & $\ldots$ & $\ldots$ & $\ldots$ & 20.0 & $\ldots$ & $\ldots$ & 20.0 & $\ldots$ & $\ldots$ & $\ldots$ & 18.0 & $\ldots$ & 25.0 & $\ldots$ & 200.0 & $\ldots$ & 200.0 \\
\hline Rural dwellers & 61.2 & 88.3 & $\cdots$ & $\cdots$ & $\cdots$ & $\cdots$ & $\cdots$ & $\cdots$ & $\ldots$ & $\cdots$ & $\cdots$ & $\cdots$ & $\cdots$ & $\cdots$ & $\cdots$ & $\cdots$ & $\cdots$ & $\cdots$ & $\cdots$ & $\cdots$ & $\cdots$ \\
\hline \multicolumn{22}{|l|}{ Transportation } \\
\hline Urban transport & 87.4 & 50.0 & $\ldots$ & 33.0 & $\ldots$ & $\ldots$ & & 500 & $\ldots$ & $\ldots$ & 66.7 & $\ldots$ & $\ldots$ & $\ldots$ & 200.0 & $\ldots$ & $\ldots$ & $\ldots$ & $\ldots$ & 200,0 & $\ldots$ \\
\hline Commuter transport & 65.8 & 139.1 & $\cdots$ & $\ldots$ & $\cdots$ & $\cdots$ & 45.5 & $\cdots$ & $\cdots$ & $\cdots$ & $\cdots$ & $\cdots$ & $\cdots$ & $\cdots$ & $\cdots$ & $\cdots$ & $\cdots$ & $\cdots$ & $\cdots$ & $\cdots$ & $\ldots$ \\
\hline \multicolumn{22}{|l|}{ Energy } \\
\hline Crude oil & 87.2 & 85.2 & $\ldots$ & $\ldots$ & $\ldots$ & $\ldots$ & $\ldots$ & $\ldots$ & $\ldots$ & $\ldots$ & & $\ldots$ & $\ldots$ & $\ldots$ & & $\ldots$ & $\ldots$ & & & $\ldots$ & $\ldots$ \\
\hline Natural gas (for conking) 2/ & 151.2 & 68.0 & $\ldots$ & $\ldots$ & $\therefore$ & $\ldots$ & $\ldots$ & $\ldots$ & $\ldots$ & $\ldots$ & 200 & $\ldots$ & $\ldots$ & $\ldots$ & 18.0 & 8.0 & 1.8 & 11.7 & 11.7 & 3 E. 0 & 10.9 \\
\hline Gasoline 3/4i & & & & & & & & & & & & & & & & & & & & . & \\
\hline Unleuded AI-76 4/ & 87.2 & 117.7 & $\ldots$ & $\ldots$ & $\cdots$ & $\cdots$ & $\ldots$ & $\cdots$ & $\cdots$ & $\cdots$ & $\ldots$ & $\ldots$ & $\ldots$ & $\ldots$ & $\ldots$ & $\ldots$ & $\ldots$ & $\ldots$ & $\ldots$ & $\ldots$ & $\ldots$ \\
\hline Leaded AI-93 $4 t$ & 87.2 & 261.2 & $\ldots$ & $\cdots$ & $\cdots$ & $\cdots$ & $\cdots$ & $\cdots$ & $\cdots$ & $\cdots$ & $\cdots$ & $\cdots$ & $\cdots$ & $\cdots$ & $\cdots$ & $\cdots$ & $\ldots$ & $\ldots$ & $\cdots$ & $\cdots$ & $\ldots$ \\
\hline Diesel fuel $3 / 4 /$ & 0.0 & 117.4 & $\ldots$ & $\ldots$ & $\ldots$ & $\ldots$ & $\ldots$ & $\ldots$ & $\ldots$ & $\ldots$ & $\ldots$ & $\cdots$ & $\ldots$ & $\ldots$ & $\ldots$ & $\ldots$ & $\ldots$ & $\ldots$ & $\ldots$ & $\ldots$ & $\ldots$ \\
\hline Fuel oil 3/4/ & 0.0 & 67.3 & $\cdots$ & $\cdots$ & $\cdots$ & $\cdots$ & $\cdots$ & $\ldots$ & $\cdots$ & $\cdots$ & $\ldots$ & $\ldots$ & $\cdots$. & $\ldots$ & $\cdots$ & $\ldots$ & $\ldots$ & $\ldots$ & $\ldots$ & $\ldots$ & ... \\
\hline \multicolumn{22}{|l|}{ Electricity (industrial tarifn) } \\
\hline Use above $750 \mathrm{Kwh}$ & $\ldots$ & $\ldots$ & $\cdots$ & 26.6 & 36.8 & 35.2 & 4.9 & $\cdots$ & $\cdots$ & $\cdots$ & $\cdots$ & $\ldots$ & $\ldots$ & $\cdots$ & $\cdots$ & $\cdots$ & $\cdots$ & $\ldots$ & $\cdots$ & $\cdots$ & ... \\
\hline Use below $750 \mathrm{Kwh}$ & $\ldots$ & $\ldots$ & $\cdots$ & 24,0 & 36.1 & 35.6 & 3.5 & $\ldots$ & ... & $\ldots$ & $\cdots$ & $\cdots$ & $\ldots$ & $\ldots$ & $\cdots$ & $\ldots$ & $\cdots$ & $\ldots$ & $\ldots$ & $\ldots$ & $\ldots$ \\
\hline \multicolumn{22}{|l|}{ Memorandum item: } \\
\hline CPI (percentage change) & 63.1 & 181.7 & 62.7 & 16.6 & 13.7 & 12.1 & 7.4 & 8.9 & 7.1 & 6.0 & 7,1 & 12.1 & 14.2 & 14,3 & 13.6 & 14.1 & 9.3 & 5.8 & 5.1 & 4.7 & 6.1 \\
\hline
\end{tabular}

Sources: Ministry of Economy; and Fund starf estimates.

1/ Payment for heating is calculated on the basis of living space; after September 1,1999 the definition was broadened. 2/ Domestic resale.

3/ For preferted users.

$4 /$ Oil product prices for households are not regulated. 
Table 12, Belarus: Tariffs and Cost Coverage for Housebolds, 1998-2000 (May) 1/

\begin{tabular}{|c|c|c|c|c|c|c|c|c|c|c|c|c|}
\hline & \multicolumn{3}{|c|}{ January 1,1998} & \multicolumn{3}{|c|}{ Jamnary 1,1999} & \multicolumn{3}{|c|}{ January 1,2000} & \multicolumn{3}{|c|}{ May 1,2000} \\
\hline & $\begin{array}{c}\text { Unit Tariff } \\
2 / \\
\text { (In rubels) }\end{array}$ & $\begin{array}{l}\text { Representative } \\
\text { Household } \\
\text { Expenditure } 3 / \\
\text { (In rubels) }\end{array}$ & $\begin{array}{c}\text { Cost } \\
\text { Coverage } \\
\text { (In percent) }\end{array}$ & $\begin{array}{c}\text { Unit Tariff } \\
2 l \\
\text { (In rubeis) }\end{array}$ & $\begin{array}{l}\text { Representative } \\
\text { Household } \\
\text { Expenditure } 3 / \\
\text { (In mbeis) }\end{array}$ & $\begin{array}{c}\text { Cost } \\
\text { Coverage } \\
\text { (In percent) }\end{array}$ & $\begin{array}{c}\text { Unit Tariff } \\
2 / \\
\text { (In nbels) }\end{array}$ & $\begin{array}{l}\text { Representative } \\
\text { Household } \\
\text { Expendinure } 3 / \\
\text { (In rubels) }\end{array}$ & $\begin{array}{c}\text { Cost } \\
\text { Coverage } \\
\text { (In percent) }\end{array}$ & $\begin{array}{c}\text { Unit Tariff } \\
2 / \\
\text { (In rubets) }\end{array}$ & $\begin{array}{l}\text { Representative } \\
\text { Household } \\
\text { Expenditure } 3 / \\
\text { (In rubels) }\end{array}$ & $\begin{array}{c}\text { Cost } \\
\text { Coverage } \\
\text { (In percent) }\end{array}$ \\
\hline Rent & 1.2 & 36.7 & 31.1 & 1.5 & 44.1 & 35.2 & 2.2 & 67.2 & 10.8 & 3.7 & 112.2 & 9.5 \\
\hline Heating & 4.9 & 146.0 & 45.3 & 4.9 & 146.0 & 38.8 & 10.3 & 309.0 & 13.8 & 14.2 & 426.6 & 8.7 \\
\hline Water & 0.6 & 15.4 & 22.1 & 4.2 & $\llbracket 12.3$ & 100.0 & 10.7 & 288.9 & 44.2 & 15.7 & 422.6 & 38.4 \\
\hline Sewage & 0.6 & 15.1 & 28.6 & 3.8 & 102.9 & 1000 & 8.4 & 226.8 & 49.1 & 12.3 & 3313 & 41.0 \\
\hline Hot water & 14.6 & 43.8 & 25.4 & 14.6 & 43.8 & 21.8 & 49.7 & 149.1 & 7.8 & 68.6 & 205.9 & 4.9 \\
\hline Radio & 4.4 & 4.4 & 64.7 & 6.4 & 6.4 & 60.0 & $\ldots$ & $\ldots$ & $\ldots$ & $\ldots$ & $\ldots$ & $\ldots$ \\
\hline Telephone & 33.0 & 33.0 & 53.2 & 48.0 & 48.0 & 64.1 & $\ldots$ & $\ldots$ & $\ldots$ & $\ldots$ & $\ldots$ & ... \\
\hline Television antenna & 3.4 & 3.4 & 60.0 & & & $\ldots$ & $\ldots$ & $\ldots$ & & $\ldots$ & $\ldots$ & \\
\hline Gas & 10.2 & 30.6 & 62.1 & 17,1 & 51.3 & 41.5 & 35.2 & 105.6 & 21.9 & 48.3 & 144,9 & 29.3 \\
\hline Electricity & 0.5 & 67.5 & 44.9 & 0.9 & 127.5 & 48.3 & 1.4 & 216.5 & 14.7 & 3.6 & 540.0 & 24.7 \\
\hline
\end{tabular}

Sources: Ministry of Housing and Communal Services; and Ministry of Econony.

I/ Data have been revised backward to reflect the redenomination of the rubel on January 1,2000 which removed three zeros from the currency

2/ Per square meter for rent and heating; per cubic meter for water and sewage; per person for hot water and gas; per kwh for electricily; and per household for radio,

elephone, and TV antenna.

3/ A representative household consists of: 1) the area of a 30-square-meter, two-bedroom apartment; with 2) each person consuming 9 cubic

meters of water and $50 \mathrm{kwh}$ of electricity per month. 
Table 13. Belanus: Average Monthly Wages, 1995-99

(In thousands of rubels) $1 /$

\begin{tabular}{|c|c|c|c|c|c|}
\hline & 1995 & 1996 & 1997 & 1998 & 1999 \\
\hline & \multicolumn{5}{|c|}{ (Annual survey) $2 /$} \\
\hline Avernge & 755 &, \pm 212 & 2,270 & 4,635 & 19,581 \\
\hline (Excluding collective farms) & 803 & 1,287 & 2,416 & 4,887 & 20,585 \\
\hline Good-producing sectors & 777 & 1,174 & 2,222 & 4,518 & 19,489 \\
\hline Construction & 1,048 & 1,474 & 2,852 & 5,796 & 25,238 \\
\hline Industry & 862 & 1,366 & 2,689 & 5,630 & 23,865 \\
\hline Forestry & 728 & 1,100 & 2,018 & 3,867 & 17,570 \\
\hline Agriculture 3/ & 468 & 758 & 1,329 & 2,777 & 11,282 \\
\hline Service-producing sectors & 840 & 1,316 & 2.415 & 4.823 & 20,367 \\
\hline Banks and insurance & 1,612 & 2,207 & 4,353 & 9,056 & 39,928 \\
\hline Administration & 1,192 & 1,750 & 3,446 & 6,439 & 24,221 \\
\hline Information and computing services & 960 & 1,513 & 2,709 & 5,842 & 24,222 \\
\hline Transport & 936 & 1,463 & 2,553 & 4,903 & 21,240 \\
\hline Science & 816 & 1,354 & 2,585 & 5,213 & 23,753 \\
\hline Conmunication & 919 & 1,352 & 2,345 & 4,707 & 21,188 \\
\hline Housing and commumal services & 753 & 1,203 & 2,071 & 4,178 & 18,180 \\
\hline Health & 652 & 1,118 & 1,958 & 3,649 & 15,290 \\
\hline Trade and catering & 607 & 1,070 & 1,945 & 4,067 & 16,397 \\
\hline Education & 595 & 1,015 & 1,874 & 3,646 & 14,577 \\
\hline Culture & 518 & 893 & 1,596 & 3,122 & 12,775 \\
\hline Arts & 517 & 859 & 1,545 & 3,061 & 12,634 \\
\hline \multicolumn{6}{|l|}{ Memorandum item: } \\
\hline \multirow[t]{2}{*}{ Collective farms } & 437 & 700 & 1,221 & 2,520 & 10,234 \\
\hline & \multicolumn{5}{|c|}{ (Percentage change from the previous year) } \\
\hline Average & 669 & $6 !$ & 87 & 104 & 322 \\
\hline (Excluding collective farms) & 670 & 60 & 88 & 102 & 321 \\
\hline Good-producing sectors & $70 \mathrm{l}$ & 53 & 87 & 103 & 330 \\
\hline Construction & 675 & 41 & 93 & 103 & 335 \\
\hline Industry & 619 & 59 & 97 & 109 & 324 \\
\hline Forestry & 862 & 5.1 & 83 & 92 & 354 \\
\hline Agriculture $3 /$ & 646 & 62 & 75 & 109 & 306 \\
\hline Service-producing sectors & 734 & 61 & 82 & 99 & $32 !$ \\
\hline Banks and insurance & 650 & 37 & 97 & 108 & 341 \\
\hline Administration & 855 & 47 & 97 & 87 & 276 \\
\hline Information and computing services & 910 & 58 & 79 & 116 & 315 \\
\hline Transport & 711 & 56 & 75 & 92 & 333 \\
\hline Science & 742 & 66 & 91 & 102 & 356 \\
\hline Communication & 871 & 47 & 74 & 101 & 350 \\
\hline Housing and communal services & 769 & 60 & 72 & 102 & 335 \\
\hline Health & 714 & 71 & 75 & 86 & 319 \\
\hline Trade and catering & 604 & 76 & 82 & 109 & 303 \\
\hline Education & 654 & 71 & 85 & 95 & 300 \\
\hline Culture & 676 & 73 & 79 & 96 & 309 \\
\hline Arts & 657 & 66 & 80 & 98 & 313 \\
\hline \multicolumn{6}{|l|}{ Memorandum items: } \\
\hline Minimum wage (in thousands of rubels, end-of-period) & 60 & 100 & 200 & 350 & 1450 \\
\hline Real average monthly wage index $(1991=100)$ & 54 & 57 & 65 & 76 & 82 \\
\hline
\end{tabular}

Sources: Ministry of Statistics and Analysis; and Fund staff estimates.

1/ Data have been revised backward to reflect the redenomination of the rubel on January 1, 2000 which removed three zeros from the currency.

2/ The average monthly wage of workers for 1995.98 are for the full range of enterprises and other entities.

3/ including coliective farms. 
Table 14. Belarus: Price and Wage Developments, 1996-2000(Q2)

(Percentage change from previous period)

\begin{tabular}{|c|c|c|c|c|c|c|}
\hline & \multirow[t]{2}{*}{1996} & \multirow[t]{2}{*}{1997} & \multirow[t]{2}{*}{1998} & \multirow[t]{2}{*}{1999.} & \multicolumn{2}{|c|}{2000} \\
\hline & & & & & Q1 & $\overline{\mathrm{Q} 2}$ \\
\hline Consumer prices (period average) & 53 & 64 & 73 & 294 & 227 & 196 \\
\hline Change at end-of-period & 39 & 63 & 182 & 251 & 212 & 191 \\
\hline Goods (period average) & 41 & 63 & 75 & 304 & 227 & 206 \\
\hline Food & 43 & 66 & 76 & 313 & 238 & 213 \\
\hline Nonfood & 30 & 49 & 74 & 275 & 188 & 180 \\
\hline Services (period average) & 30 & 66 & 56 & 212 & 237 & 254 \\
\hline Producer prices (period average) & 34 & 88 & 72 & 356 & 181 & 179 \\
\hline Change at end-of-period & 31 & 89 & 200 & 245 & 168 & 190 \\
\hline Industrial goods & 26 & 95 & 216 & 220 & 144 & 174 \\
\hline Consumer goods & 42 & 84 & 179 & 291 & 219 & 222 \\
\hline Minimum wage (end-of-period) & 67 & 100 & 75 & 4,043 & 2,800 & 1,350 \\
\hline Average monthly wage & 61 & 88 & 105 & 250 & 289 & 202 \\
\hline Real wage (period average) & 4 & 14 & 22 & 4 & 25 & 4 \\
\hline
\end{tabular}

Sources: Ministry of Statistics and Analysis; and Fund staff estimates. 
Table 15. Belarus: Money Income and Expenditures of the Population, 1996-2000 (Q1)

1996

1997

1998

$1999-\frac{2000}{\mathrm{QI}}$

(In millions of rubels) 1

Money incomes

Salaries and wages of workers, and employees of collective farms

Revenues from sale of agricultural products

Pensions, benefits, and scholarships

Revenues from financial system 2 /

Revenues of population from officially unaccounted business and other activities

Expenditures

Consumption of goods and payments for services

Taxes and other obligatory payments and voluntary contributions

Accumulation of savings in deposit accounts, securities, and foreign currency purchases

Unallocated income

Salaries and wages of workers, and employees of collective farms

Revenues from sale of agricultural products

Pensions, benefits, and scholarships

Revenues from financial system $2 /$

Reverues of population from officially

unaccounted business and other activities

Saving rate $3 /$

136,979

238,228

492,129

$1,889,326$

946,000

63,553
1,726
23,159
1,622

127,231

3,308

245,333

$1,034,516$

503,000

42,109

7,792

39,074

5,000

8,267

82,798

329,087

181,000

46,919

57,313

138,431

433,580

257,000

134,801

232,738

484,742

$1,859,437$

935,000

100,033

185,893

387,88

$1,625,369$

768,000

7,903

22,565

43,467

152,707

75,000

26,865

24,280

53,391

81,361

92,000

2,178

5,490

7,387

29,889

11,000

(As a percent of income)

\begin{tabular}{rrrrr}
46.4 & 53.4 & 49.9 & 54.8 & 53.2 \\
1.3 & 1.4 & 1.6 & 2.1 & 0.5 \\
16.9 & 17.7 & 16.8 & 17.4 & 19.1 \\
1.2 & 3.5 & 3.6 & 2.8 & \\
34.3 & 24.1 & 28.1 & 22.9 & 27.2 \\
21 & 11 & 12 & 5 & 11 \\
\hline
\end{tabular}

Sources: Ministry of Statistics and Analysis; Ministry of Economy; and Fund staff estimates.

1/ Data have been revised backward to reflect the redenomination of the rubel on January 1,2000 removing three zeros from the currency.

2/ Beginning in January 2000, the item "Revenues from the financial system" is removed from the revenue side of the income balance. The reason for this is that credits received from the population are not current revenues, but equivalent to a change in financial assets.It is included in the item "Accumulation of savings in deposit accounts, in securities, and the purchase of foreign exchange" on theexpenditure side.

$3 /$ Including securities and foreign exchange deposits; expressed as a percent of money income as defined for tax purposes. 
Table 16. Belarus: Labor Market Indicators, 1996-2000 (Q1)

1996

1997

1998

1999

$\frac{2000}{\mathrm{Q} 1}$

(In thousands of persons)

Employment $1 /$

Job leavers

Jobs taken up

Number of unemployed at the end of the period $2 /$

Officially recognized

Of which:

Benefit recipients

Long-term unemployed 3

Activity of the Employment Burean

Applications from job seekers

Placements

Vacancies

Unemployment rate (in percent) 4 '

Of which:

Benefit recipients (in percent)

Economically active population $5 /$

Memorandum items:

Labor force participation rate 6/

Economically active population as share of

working-age population

Share of women in the labor force $7 /$

Share of women in total number of unemployed
4,365

769.0

678.0

182.5

85.0

28.0

300.0

150.0

16.0

271.4

207.7

308.5

284.2

64.9

29.4

241.1

30.3

223.1

44.1

43.7

$\begin{array}{rrrr}3.9 & 2.8 & 2.3 & 2.1 \\ & & & \\ 1.8 & 1.0 & 0.9 & 0.9 \\ 4,537.0 & 4,527.9 & 4,527.8 & 4,542.0\end{array}$

(In percent)

44.3

$$
44.3
$$

44.4

78.5

79.0

51.7

63.8
51.7

66.6
77.9

51.8

66.7
2.1

..

..

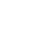

$\ldots$

...

...

61.5

Sources: Belanusian authorities; and Fund staff estimates.

1/ Average employment during the year for annual data; end-of-period data for Q1 2000.

2/ Unemployed is any able-bodied person without a job other than: those engaged in business, those in education or training, or those serving in the armed forces. The definition was widened in 1993.

3/ Unemployed for more than one year.

4/ Number of registered unemployed expressed as a percentage of the economically active population.

$5 /$ Working-age population comprises all people able to work older than 16 years and below the retirement age. The economically activepopulation excludes, among others, students, housewives, and members of the armed forces.

6/ Defined as the economically active population in percent of total population.

7/ Women on leave for matemity or caring for children under three years of age are exluded from the economically active population. 
Table 17. Belarus: Average Monthly Employment by Sector, 1996-2000 (Q1)

\begin{tabular}{|c|c|c|c|c|c|c|c|c|c|c|}
\hline & 1996 & 1997 & 1998 & 1999 & $\frac{2000}{Q 1}$ & 1996 & 1997 & 1998 & 1999 & $\frac{2000}{\mathrm{Q}}$ \\
\hline & \multicolumn{4}{|c|}{ (In thousands) } & & \multicolumn{5}{|c|}{ (Percentage change over previous period) } \\
\hline Annual survey $1 /$ & 4,365 & 4,370 & 4,417 & 4,442 & 4,384 & -1.0 & 0.1 & 1.1 & 0.6 & 0.2 \\
\hline Monthly survey & 3,685 & 3,708 & 3,738 & 3,745 & 3,638 & -3.4 & 0.6 & 0.8 & 0.2 & -2.9 \\
\hline Good-producing sectors & 2,088 & 2,063 & 2,036 & 1,993 & 1,906 & -6.8 & & & & \\
\hline Industry & 1,081 & 1,072 & 1,073 & 1,084 & 1,071 & -6.8 & -0.8 & 0.1 & 1.0 & -0.9 \\
\hline Agriculture $2 /$ & 759 & 738 & 698 & 646 & 581 & -5.5 & -2.8 & -5.4 & -7.4 & -6.0 \\
\hline Construction & 248 & 253 & 265 & 263 & 254 & -10.8 & 2.0 & 4.7 & -0.8 & $-4,2$ \\
\hline Sevice-producing sectors & 1,597 & 1,645 & 1,702 & 1,752 & 1,732 & 1.6 & & & & \\
\hline Transport and communication & 277 & 279 & 284 & 286 & 275 & -1.1 & 0.7 & 1.8 & 0.7 & -3.5 \\
\hline Trade and rclated services & 216 & 227 & 238 & 249 & 255 & -3.1 & 5.1 & 4.8 & 4.6 & -0.4 \\
\hline Communal services & 125 & 128 & 133 & 141 & 148 & 13.5 & 1.6 & 3.9 & 6.0 & 2.1 \\
\hline Health and social services & 264 & 271 & 279 & 283 & 282 & 1.5 & 2.7 & 3.0 & 1.4 & -1.7 \\
\hline Education, culture, and science & 471 & 489 & 506 & 521 & 529 & 2.2 & 3.8 & 3.5 & 3.0 & -0.6 \\
\hline Banks and insurance & 45 & 46 & 49 & 52 & 53 & 0.0 & 2.2 & 6.5 & 6.1 & 0.0 \\
\hline Administration & 75 & 75 & 78 & 82 & 80 & 2.7 & 0.0 & 4.0 & 5.1 & -3.6 \\
\hline \multirow[t]{2}{*}{ Other } & 124 & 130 & 135 & 138 & 110 & 3.3 & 4.8 & 3.8 & 2.2 & -21.4 \\
\hline & \multicolumn{4}{|c|}{ (Share in total) } & & \multicolumn{5}{|c|}{ (Percentage change of share in totat) } \\
\hline Good-producing sectors & 56.7 & 55.7 & 54.5 & 53.1 & 52.4 & -3.6 & -1.7 & -2.1 & -1.8 & -3.9 \\
\hline Industry & 29.3 & 28.9 & 28.7 & 28.9 & 29.4 & -3.6 & -1.3 & -0.9 & .0 .7 & 2.4 \\
\hline Agriculture 2/ & 20.6 & 19.9 & 18.7 & 17.2 & 16.0 & -2.2 & .5 .9 & -6.0 & -4.5 & -14.4 \\
\hline Construction & 6.7 & 6.8 & 7.1 & 7.0 & 7.0 & -7.7 & 1.5 & 3.9 & 0.7 & -1.4 \\
\hline Sevice-producing sectors & 43.4 & 44.6 & 45.5 & 46.9 & 47.6 & 6.1 & 2.7 & 2.1 & 2.1 & 4.6 \\
\hline Transport and communication & 7.5 & 7.5 & 7.6 & 7.6 & 7.6 & 2.4 & 0.2 & 0.9 & -1.4 & 0.0 \\
\hline Trade and related services & 5.9 & 6.1 & 6.4 & 6.7 & $7.0^{\circ}$ & 6.6 & 4.6 & 4.4 & 4.2 & 9.4 \\
\hline Communal services & 3.4 & 3.4 & 3.5 & 3.8 & 4.1 & 18.5 & -0.6 & 2.9 & 6.5 & 17.1 \\
\hline Ifealth and social services & 7.2 & 7.3 & 7.5 & 7.6 & 7.8 & 5.1 & 2.2 & 2.5 & 1.1 & 4.0 \\
\hline Education, culture, and science & 12.8 & 13.2 & 13,5 & 13.9 & 14.5 & 5.7 & 3.3 & 2.3 & 1.2 & 7.4 \\
\hline Banks and insurance & 1.2 & 1.2 & 1.3 & 1.4 & 1.5 & 3.5 & 1.7 & 4.7 & 9.3 & 15.4 \\
\hline Administration & 2.0 & 2.0 & 2.1 & 2.2 & 2.1 & 6.3 & -0.5 & 3.7 & 4.9 & 0.0 \\
\hline Other & 3.4 & 3.7 & 3.6 & 3.7 & 3.0 & 6.9 & 10.0 & -2.7 & 2.9 & -16.7 \\
\hline
\end{tabular}

Sources: Ministry of Statistics and Analysis; and Fund staff estimates.

1/ Based an comprehensive annual survey data that include enterprises of all types of ownership (including snuall businesses) and individuats engaged in private enterprises. 2/ Approximately two thirds from collective farms. 
Table 18. Belanis: Enterprise Profits and Losses, 1996-2000 (Q1)

\begin{tabular}{|c|c|c|c|c|c|}
\hline & 1996 & 1997 & 1998 & 1999 & $\frac{2000}{\mathrm{Q} 1}$ \\
\hline & \multicolumn{5}{|c|}{ (Profitability of enterprises) $1 /$} \\
\hline Total economy & 9.7 & 10.1 & 10.9 & 14.7 & 9.5 \\
\hline $\begin{array}{l}\text { Industry } \\
\text { Of which: }\end{array}$ & \multicolumn{4}{|c|}{ Of which: } & 12.5 \\
\hline Power generation & 2.7 & 4.0 & 2.8 & 3.9 & -9.0 \\
\hline Refineries & 24.4 & 23.7 & 19.9 & 31.4 & 34.0 \\
\hline Ferrous metallurgy & 12.0 & 14.4 & 16.9 & 13.4 & 17.2 \\
\hline Chemicals & 10.4 & 14.5 & 20.9 & 27.3 & 22.7 \\
\hline Petrochernicals & 9.4 & 10.8 & 8.8 & 10.6 & 8.5 \\
\hline Machine building & 9.1 & 15.4 & 15.6 & 18.2 & 12.2 \\
\hline Wood and paper & 13.4 & 17.5 & 21.3 & 17.7 & 13.4 \\
\hline Constnuction materials & 5.9 & 8.6 & 6.4 & 7.9 & -3.4 \\
\hline Light industry & 11.0 & 14.5 & 20.7 & 22.5 & 16.9 \\
\hline Food incustry & 12.8 & 12.7 & 12.9 & 13.3 & 8.8 \\
\hline \multicolumn{6}{|l|}{ Agriculture 2/ } \\
\hline Collective farms & 11.5 & 13.8 & 3.2 & 12.4 & $\ldots$ \\
\hline \multirow[t]{2}{*}{ State farms } & 8.6 & 7.6 & 1.5 & 11.1 & $\cdots$ \\
\hline & \multicolumn{5}{|c|}{ (Number of loss-making enterprises) } \\
\hline Total & 1,737 & 1,351 & 1,815 & 1,924 & 3,836 \\
\hline \multicolumn{6}{|l|}{ Of which: } \\
\hline Industry & 324 & 264 & 246 & 216 & 693 \\
\hline \multirow[t]{2}{*}{ Agriculture 2/ } & 471 & 369 & 1,170 & 1,121 & $\cdots$ \\
\hline & \multicolumn{5}{|c|}{ (Share of loss-making enterprises per sector in percent) } \\
\hline Total economy & 18.4 & 12.3 & 16.2 & 17.1 & 33.9 \\
\hline $\begin{array}{l}\text { Industry } \\
\text { Of which: }\end{array}$ & 17.6 & 11.8 & 10.5 & 9.2 & 29.3 \\
\hline \multicolumn{6}{|l|}{ Of which } \\
\hline Refineries & $\ldots$ & 0.0 & 0.0 & 0,0 & 0.0 \\
\hline Ferrous metallurgy & $\ldots$ & 0.0 & 0.0 & 6.3 & 25.0 \\
\hline Chemicals & 11.1 & 2.4 & 1.9 & 9.6 & 25.0 \\
\hline Petrochemicals & $\ldots$ & $\ldots$ & 10.0 & 10.0 & 44.4 \\
\hline Machine building & 13.4 & 8.2 & 8.0 & 7.7 & 25.2 \\
\hline Wood and paper & 9.1 & 7.7 & 8.3 & 8.6 & 25.5 \\
\hline Construction materials & 33.8 & 24.4 & 22.0 & 21.4 & 60.8 \\
\hline Light industry & 39.0 & 22.2 & 15.5 & 13.6 & 33.4 \\
\hline Food industry & 9.8 & 7.5 & 5.4 & 3.0 & 24.7 \\
\hline
\end{tabular}

Sources: Ministry of Statistics and Analysis; and Fund staff estimates.

1/ Profitability is defined as profits from sales as a percent of cost of sold products. With the exception of power generation, enterprises in this sample are those with an exclusively positive profitability.

2/ Includes state and collective farms. 
Table 19. Belarus: Interenterprise Arrears and the Barter Econony, 1996-2000 (Q1)

(End-of-period stocks in cument prices)

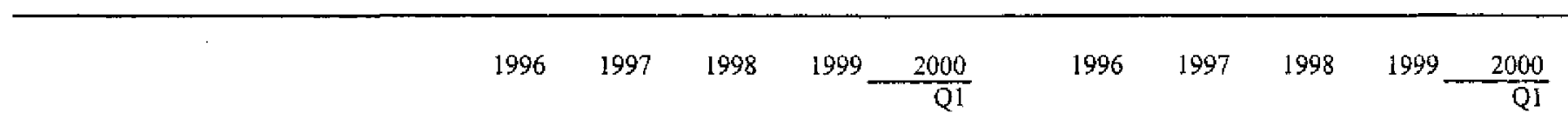

(In bilitions of rubels) $1 /$

(In percent of GDP)

Overdue accounts receivable

\begin{tabular}{|c|c|c|c|c|c|c|c|c|c|}
\hline Total & 31 & 42 & 110 & 419 & 628 & 17.0 & 11.7 & 16.2 & 14.5 \\
\hline Industry & 15 & 20 & 41 & 199 & 281 & 7.9 & 5.7 & 6.1 & 6.9 \\
\hline Agricultute & 1 & 1 & 1 & 6 & 8 & 0.4 & 0.3 & 0.2 & 0.2 \\
\hline Construction & $t$ & 2 & 3 & 9 & 19 & 0.7 & 0.4 & 0.4 & 0.3 \\
\hline Transport & 9 & 11 & 40 & 95 & 157 & 4.9 & 3.1 & 5.9 & 3.3 \\
\hline Communications & 0 & 0 & 0 & 1 & 1 & 0.1 & 0.1 & 0.0 & 0.0 \\
\hline Trade and public catering & 0 & 0 & $t$ & 3 & 7 & 0.2 & 0.1 & 0.1 & 0.1 \\
\hline Supply and sales & 1 & 1 & 5 & 21 & 29 & 0.3 & 0.2 & 0.8 & 0.7 \\
\hline Housing and communal services & 4 & 6 & 18 & 85 & 124 & 2.4 & 1.7 & 2.6 & 2.9 \\
\hline
\end{tabular}

Overdue accounts payable $2 /$

$\begin{array}{lrrrrrrrrrr}\text { Total } & 34 & 47 & 156 & 555 & 861 & 18.2 & 13.3 & 23.1 & 19.2 & 66.8 \\ \text { Industry } & 19 & 26 & 76 & 311 & 480 & 10.2 & 7.2 & 11.3 & 10.7 & 37.2 \\ \text { Agriculture } & 4 & 7 & 14 & 63 & 76 & 2.2 & 1.9 & 2.0 & 2.2 & 5.9 \\ \text { Construction } & 1 & 1 & 3 & 8 & 18 & 0.7 & 0.4 & 0.4 & 0.3 & 1.4 \\ \text { Transport } & 3 & 4 & 29 & 66 & 112 & 1.9 & 1.3 & 4.3 & 2.3 & 8.7 \\ \text { Communications } & 0 & 0 & 1 & 3 & 5 & 0.0 & 0.0 & 0.1 & 0.1 & 0.4 \\ \text { Trade and public catering } & 1 & 2 & 3 & 14 & 24 & 0.5 & 0.4 & 0.5 & 0.5 & 1.9 \\ \text { Supply and sales } & 1 & 1 & 11 & 16 & 20 & 0.3 & 0.3 & 1.7 & 0.5 & 1.6 \\ \text { Housing and communal services } & 4 & 6 & 19 & 74 & 124 & 2.4 & 1.7 & 2.8 & 2.6 & 9.6\end{array}$

Barter transactions

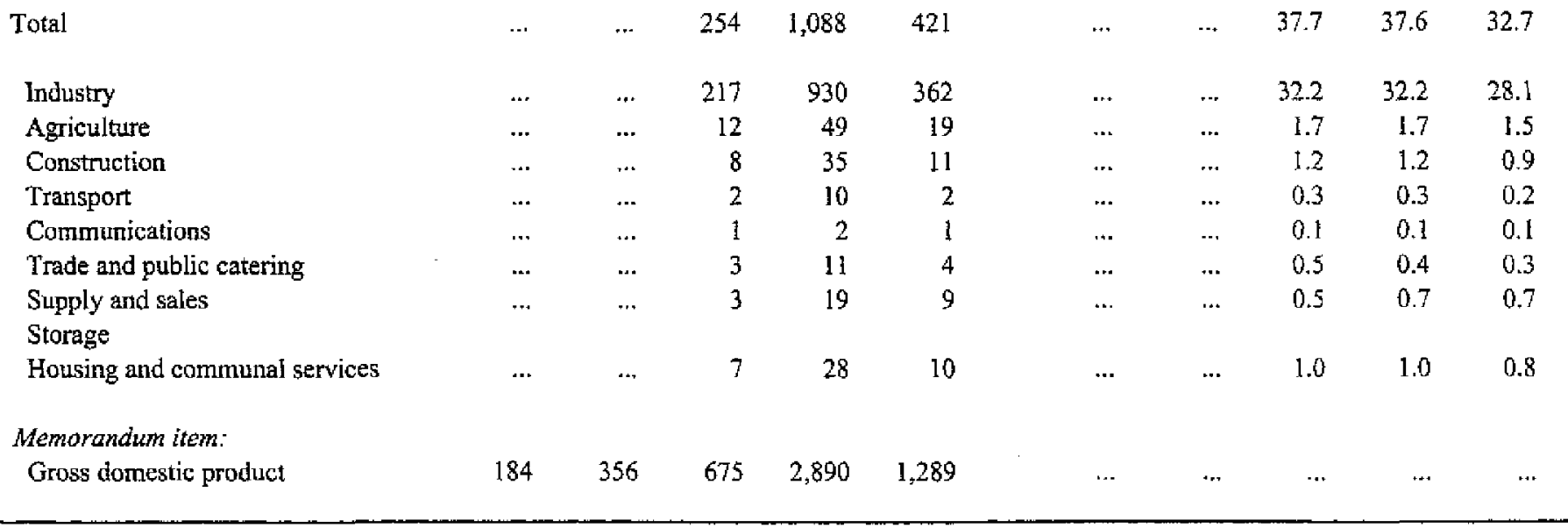

Sources: Ministry of Statistics and Analysis; and Fund staff estimates.

1/ Data have been revised backward to reflect the redenomination of the rubel on January 1,2000 which removed three zeros from the currency. 2/Overdue accounts payable only include overdue payments to the republican and local governments, workers, and to other entities for goods and services. 
Table 20. Belarus: Sectoral Distribution of Energy Debts of Enterprises, 1997-99 I/

\begin{tabular}{|c|c|c|c|c|c|c|c|c|c|c|c|c|}
\hline - & \multicolumn{4}{|c|}{1997} & \multicolumn{4}{|c|}{1998} & \multicolumn{4}{|c|}{1999} \\
\hline & Total & Gas & Oil & Electricity & Totak & Gas & ói & Electricity & Total & Gas & Oil & Electricity \\
\hline \multirow[b]{2}{*}{ Domeslje debts } & \multicolumn{12}{|c|}{ (In billions of rubels) $2 /$} \\
\hline & 30.30 & 19.05 & $\cdots$ & 9.59 & 96.02 & 60.31 & $\ldots$ & 33.71 & 377.25 & 206.44 & $\ldots$ & 160.88 \\
\hline Industry & 15.77 & 9.55 & $\ldots$ & 5.98 & 53.57 & 27.56 & $\ldots$ & 25.25 & 225.82 & 105.68 & $\ldots$ & 115,00 \\
\hline Agricultufe & 3.61 & 0.51 & $\ldots$ & 2.97 & 9.05 & 1.63 & ... & 7.15 & 46.04 & 7.03 & $\ldots$ & 38.20 \\
\hline Transportation, including pipelints & 0.12 & 0.01 & $\ldots$ & 0.05 & 0.53 & 0.20 & ... & 0.14 & 10.49 & 7.99 & $\ldots$ & 0.88 \\
\hline Comtrunications & 0.00 & & $\ldots$ & & 0.00 & & ... & 0.00 & 0.13 & & $\ldots$ & 0.12 \\
\hline Construction & 0.10 & 0.01 & $\ldots$ & 0.06 & 0.23 & 0,04 & ... & 0.16 & 0.85 & 0.21 & $\ldots$ & 0.51 \\
\hline Trade and public catering & 0.02 & & $\ldots$ & 0.02 & 0.07 & 0.00 & $\ldots$ & 0.06 & 0.45 & 0.00 & $\ldots$ & 0.15 \\
\hline Supply and sale & 1.13 & 0.01 & $\ldots$ & 0.03 & 0.58 & 0.00 & $\ldots$ & 0.05 & 0.86 & 0.00 & $\ldots$ & 0.28 \\
\hline Housing and communal services & 9.53 & 8.96 & $\ldots$ & 0.47 & 31.93 & 30.87 & $\ldots$ & 0.86 & 92.40 & 85.48 & $\ldots$ & 5.60 \\
\hline \multirow[t]{2}{*}{ Other } & 0.02 & 0.00 & $\cdots$ & 0.02 & 0.06 & 0.01 & $\ldots$ & 0.05 & 0.20 & 0.03 & $\ldots$ & 0.14 \\
\hline & \multicolumn{12}{|c|}{ (ln millions of U.S. dollars) } \\
\hline Foreiga debts & 0.13 & 0.10 & 0,00 & 0.03 & 0.37 & 0.24 & 0.01 & 0.13 & & & & \\
\hline \multicolumn{13}{|l|}{ Industry } \\
\hline Agriculture & 0.03 & ... & 0.00 & 0.03 & 0.14 & 0.00 & 0.01 & 0.13 & $\ldots$ & $\ldots$ & $\ldots$ & $\ldots$ \\
\hline Transportation, including pipelines & & & $\ldots$ & $\ldots$ & ... & $\ldots$ & $\ldots$ & $\ldots$ & $\ldots$ & $\ldots$ & $\ldots$ & ... \\
\hline Commenications & 0.10 & 0.10 & $\ldots$ & $\ldots$ & 0.23 & 0.23 & $\ldots$ & $\ldots$ & $\ldots$ & $\ldots$ & $\ldots$ & $\ldots$ \\
\hline Construction & $\ldots$ & $\ldots$ & $\ldots$ & $\ldots$ & $\ldots$ & $\ldots$ & $\ldots$ & $\ldots$ & $\ldots$ & $\ldots$ & $\ldots$ & $\ldots$ \\
\hline Trade and public catering & $\ldots$ & $\cdots$ & $\cdots$ & $\cdots$ & -. & $\ldots$ & $\ldots$ & $\ldots$ & ... & $\ldots$ & $\cdots$ & $\cdots$ \\
\hline Supply and sale & $\ldots$ & $\ldots$ & $\ldots$ & $\omega$ & $\cdots$ & $\ldots$ & $\ldots$ & $\ldots$ & $\ldots$ & $\ldots$ & $\ldots$ & $\ldots$ \\
\hline Housing end communal services & 0.00 & $\ldots$ & $\ldots$ & -. & 0.00 & 0.00 & $\ldots$ & $\ldots$ & $\ldots$ & $\ldots$ & $\ldots$ & ... \\
\hline Other & $\cdots$ & $\cdots$ & $\ldots$ & $\cdots$ & $\cdots$ & $\cdots$ & $\cdots$ & $\cdots$ & $\cdots$ & $\cdots$ & $\cdots$ & $\cdots$ \\
\hline & \multicolumn{12}{|c|}{ (As a percent of domestic debts, total and by type of energy) } \\
\hline \multicolumn{13}{|l|}{ Domestic debts by sector } \\
\hline Industry & 52 & 50 & $\ldots$ & 62 & 56 & 46 & $\ldots$ & 75 & ... & $\ldots$ & ... & $\ldots$ \\
\hline Agriculture & 12 & 3 & $\ldots$ & 31 & 9 & 3 & $\cdots$ & 21 & $\cdots$ & $\cdots$ & ... & $\ldots$ \\
\hline \multicolumn{13}{|l|}{ Forejgn debts by sector } \\
\hline Industry & 23 & $\ldots$ & 100 & 100 & 37 & 1 & 100 & 100 & $\ldots$ & ... & $\cdots$ & $\cdots$ \\
\hline \multirow[t]{2}{*}{ Transportation, including pipelines } & 77 & 100 & $\cdots$ & $\cdots$ & 62 & 99 & $\cdots$ & $\cdots$ & $\cdots$ & $\cdots$ & $\ldots$ & $\cdots$ \\
\hline & \multicolumn{12}{|c|}{ (As a percent of GDP) } \\
\hline Mentorandum items: & & & & & & & & & & & & \\
\hline Dornest ic energy debts & 9 & 5 & $\cdots$ & 3 & 14 & 9 & $\cdots$ & 5 & $\cdots$ & ... & $\cdots$ & $\cdots$ \\
\hline Foreign energy debts & 1 & 1 & 0 & 0 & 6 & 4 & $m$ & 2 & $\ldots$ & $\ldots$ & $\ldots$ & ... \\
\hline
\end{tabular}

Sources: Ministry of Statistics snd Analysis; and Fund staff estimales.

$1 /$ These debts are not necessurily overdue

2/ Data tave been revised backward to rcficcl the redenomination of the rubel on January 1,2000 which removed three zeros from the curency. 
Table 21. Belarus: General Government Operations, 1996-2000 (Q1)

(h) mitlions of nubels) $1 /$

\begin{tabular}{|c|c|c|c|c|c|}
\hline & 1996 & 1997 & 1998 & 1999 & $\frac{2000}{Q 1}$ \\
\hline Revenue and grants & 75,199 & 159,896 & 304,164 & $1,332,105$ & 649,681 \\
\hline Revenue (excluding extrabudgetary funds) & 75,199 & 159,896 & 304,164 & $1,332,105$ & 649,681 \\
\hline Current tevenue & 74,539 & 158,362 & 301,145 & $1,322,558$ & 647,820 \\
\hline Tax revenue & 68,707 & 150,038 & 280,691 & $1,231,549$ & 115,459 \\
\hline Income, profits, capital gains & 12,735 & 28,195 & 55,995 & 235,750 & 44,692 \\
\hline Social security contributions & 15,796 & 31,639 & 61,480 & 262,858 & 136,544 \\
\hline Payroll taxes & 4,870 & 7,794 & 10,803 & 47,232 & 12,292 \\
\hline Taxes on property & 1,852 & 4,935 & 9,029 & 18,051 & 14,494 \\
\hline Domestic taxes on goods and services & 29,258 & 66,153 & 123,664 & 587,652 & 268,400 \\
\hline Taxes on intemational trade and transactions & 3,169 & 8,964 & 15,269 & 58,011 & 21,166 \\
\hline Nontax reverue & 5,833 & 8,325 & 20,454 & 91,009 & 69,032 \\
\hline Capital revenue & 660 & 1,533 & 3,019 & 9,546 & 1,861 \\
\hline Grants & 0 & 0 & 0 & 0 & 0 \\
\hline \multicolumn{6}{|l|}{ Fuctionai classification } \\
\hline Expenditure & 78,654 & 164,312 & 307,632 & $1,385,001$ & 640,034 \\
\hline General public services & 3,721 & 8,727 & 15,266 & 59,800 & 23,142 \\
\hline Defense & 2,264 & 6,080 & 9,837 & 38,741 & 18,653 \\
\hline Public order & 2,979 & 4,985 & 8,501 & 41,795 & 21,687 \\
\hline Education & 11,688 & 26,283 & 47,610 & 185,708 & 93,829 \\
\hline Health &, 013 & 19,913 & 32,218 & 142,702 & 69,189 \\
\hline Social security and welfare & 872 & 36,592 & 70,973 & 286,161 & 151,326 \\
\hline Housing and communal amenizies &, 041 & 10,563 & 7,163 & 81,388 & 33,832 \\
\hline Recreation and culture &, 629 & 4,292 & 7,719 & 28,581 & 13,175 \\
\hline Indusiry, construction, and energy sectors & 556 & 1,078 & 2,904 & 17,076 & 3,524 \\
\hline Agriculture, forestry, fishing, and hunting & 944 & 12,314 & 23,322 & 124,882 & 67,493 \\
\hline Mining, manutacturing, and constnuction & 120 & 1,640 & 887 & 3,399 & 669 \\
\hline Transport and communications & 4,352 & 11,663 & 22,237 & 103,210 & 42,951 \\
\hline Other cconomic affairs and services, including research & 1,799 & 6,217 & 19,857 & 27,368 & 14,501 \\
\hline Other expendiare, including disasters and emergencies & 11,678 & 13,964 & 29,138 & 244,190 & 86,062 \\
\hline \multicolumn{6}{|l|}{ Economic dassification } \\
\hline Expenditure and net lending & 78,654 & 164,312 & 307,632 & $1,385,001$ & 640,034 \\
\hline Expenditure & 78,688 & 162,532 & 307,808 & $1,382,258$ & 640,396 \\
\hline Current expenditure & 64,923 & 130,214 & 248,253 & $1,059,185$ & 530,290 \\
\hline Expenditure on goods and services & 33,942 & 65,158 & 122,522 & 483,558 & 231,733 \\
\hline Wages and salaries & 15,274 & 28,438 & 54,347 & 221,065 & 117,529 \\
\hline Goods and services & 18,668 & $36,72 !$ & 68,174 & 262,494 & 114,204 \\
\hline Interest payments & 1,227 & 2,374 & 5,087 & 19,512 & 13,179 \\
\hline Subsidies and current transfers & 29,754 & 62,682 & 120,644 & 556,115 & 285,378 \\
\hline Subsidies & 7,821 & 16,898 & 37,218 & 195,002 & 91,645 \\
\hline Transfers to householits & 21,709 & 45,784 & 81,899 & 350,644 & 192,274 \\
\hline Transfers abroad & 224 & 0 & 1,532 & 10,469 & 1,459 \\
\hline Capital expenditure & 13,765 & 32,318 & 59,555 & 323,072 & 110,106 \\
\hline Net lending & -34 & 1,780 & -176 & 2,744 & -362 \\
\hline Balance & $-3,455$ & $-4,416$ & $-3,468$ & $-52,897$ & 9,647 \\
\hline Financing & 3,455 & 4,416 & 3,468 & 52,897 & $-9,647$ \\
\hline Foreign & -223 & 1,609 & $-1,979$ & $-24,432$ & $-9,990$ \\
\hline Domestic & 3,678 & 2,807 & 5,447 & 77,329 & 344 \\
\hline
\end{tabular}

Source: Belarusian authorities.

1/ Data have heen revised backward to reflect the redenomination of the rubel on January 1,2000 which removed three zeros from the curency. 
Table 22. Belarus: General Government Operations, 1996-2000 (Q1) 1/

(In percent of GDP)

\begin{tabular}{|c|c|c|c|c|c|}
\hline & 1996 & 1997 & 1998 & 1999 & 2000 \\
\hline Revenue and grants & 40.8 & 44.9 & 45.1 & 46.1 & 50.4 \\
\hline Revenue & 36.7 & 40.4 & 40.5 & 41.5 & 45.4 \\
\hline Curtent revenue & 40.5 & 44.5 & 44.6 & 45.8 & 50.3 \\
\hline Tax revenue & 37.3 & 42.1 & 41.6 & 42.6 & 9.0 \\
\hline Income, profits, and capital gains & 6.9 & 7.9 & 8.3 & 8.2 & 3.5 \\
\hline Social security contributions & 8.6 & 8.9 & 9.1 & 9.1 & 10.6 \\
\hline Payroll taxes & 2.6 & 2.2 & 1.6 & 1.6 & 1.0 \\
\hline Taxes on property & 1.0 & 1.4 & 1.3 & 0.6 & I.1 \\
\hline Domestic taxes on goods and services & 15.9 & 18.6 & 18.3 & 20.3 & 20.8 \\
\hline Taxes on international trade and transactions & 1.7 & 2.5 & 2.3 & 2.0 & 1.6 \\
\hline Nontax revenue & 3.2 & 2.3 & 3.0 & 3.1 & 5.4 \\
\hline Capital revenue & 0.4 & 0.4 & 0.4 & 0.3 & 0.1 \\
\hline Grants & 0.0 & 0.0 & 0.0 & 0.0 & 0.0 \\
\hline \multicolumn{6}{|l|}{ Fuctional classification } \\
\hline Expenditure & 42.7 & 46.1 & 45.6 & 47.9 & 49.7 \\
\hline General public services & 2.0 & 2.5 & 2.3 & 2.1 & 1.8 \\
\hline Defense & 1.2 & 1.7 & 1.5 & 1.3 & 1.4 \\
\hline Public order & 1.6 & 1,4 & 1.3 & 1.4 & 1.7 \\
\hline Education & 6.3 & 7,4 & 7.1 & 6.4 & 7.3 \\
\hline Health & 4.9 & 5.6 & 4.8 & 4.9 & 5.4 \\
\hline Social security and wetfare & 10.8 & 10.3 & 10.5 & 9.9 & 11.7 \\
\hline Housing and communal antenities & 2.2 & 3.0 & 2.5 & 2.8 & 2.6 \\
\hline Recreation and culture & 0.9 & 1.2 & 1.1 & 1.0 & 1.0 \\
\hline Fusl and energy sectors & 0.3 & 0.3 & 0.4 & 0.6 & 0.3 \\
\hline Agricujture, forestry, fishing, and bunting & 2.7 & 3.5 & 3.5 & 4.3 & 5.2 \\
\hline Mining, manufacturing, and construction & 0.1 & 0.5 & 0.1 & 0.1 & 0.1 \\
\hline Transport and cornmunications & 2.4 & 3.3 & 3.3 & 3.6 & 3.3 \\
\hline Other economic affairs and services, incl. research & 1.0 & 1.7 & 2.9 & 0.9 & 1.1 \\
\hline Other expenditure, incl. disasters and emergencies & 6.3 & 3.9 & 4.3 & 8.4 & 6.7 \\
\hline Adjustment & 0.0 & 0.0 & 0.0 & 0.0 & 0.0 \\
\hline \multicolumn{6}{|l|}{ Economic classification } \\
\hline Expenditure and net lending & 42.7 & 46.1 & 45.6 & 47.9 & 49.7 \\
\hline Expenditure & 42.7 & 45.6 & 45.6 & 47.8 & 49.7 \\
\hline Current expenditure & 35.3 & 36.6 & 36.8 & 36.6 & 41.1 \\
\hline Expendinure on goods and services & 18.4 & 18.3 & 18.1 & 16.7 & 18.0 \\
\hline Wages and salaries & 8.3 & 8.0 & 8.0 & 7.6 & 9.1 \\
\hline Goods and services & 10.1 & 10.3 & 10.1 & 9.1 & 8.9 \\
\hline Interest payments & 0.7 & 0.7 & 0.8 & 0.7 & 1,0 \\
\hline Subsidies and current transfers & 16.2 & 17.6 & 17.9 & 19.2 & 22.1 \\
\hline Subsidies & 4.2 & 4.7 & 5.5 & 6.7 & 7.1 \\
\hline Transfers to households & 11.8 & 12.9 & 12.1 & 12.1 & 14.9 \\
\hline Transfers abroad & 0.1 & 0.0 & 0.2 & 0.4 & 0.1 \\
\hline Capital expenditure & 7.5 & 9.1 & 8.8 & 11,2 & 8.5 \\
\hline Balance & -1.9 & -1.2 & -0.5 & -1.8 & 0.7 \\
\hline Financing & 1.9 & 1.2 & 0.5 & 1.8 & -0.7 \\
\hline Foreign & -0.1 & 0.5 & -0.3 & -0.8 & -0.8 \\
\hline Domestic & 2.0 & 0.8 & 0.8 & 2.7 & 0.0 \\
\hline \multicolumn{6}{|l|}{ Memorandum item: } \\
\hline Quasi-fiscai deficit & -2.4 & -29 & -3.0 & -3.5 & -1.4 \\
\hline
\end{tabular}

Sources: Belarusian authorities; and Fund staff estimates.

1/ Includes Social Protection Fund. 
Table 23. Belarus: Tax Arrears, 1995-99

(In billions of rubels, unless otherwise indicated; end of period)

\begin{tabular}{|c|c|c|c|c|c|}
\hline & 1995 & 1996 & 1997 & 1998 & 1999 \\
\hline Total tax arrears & 2,509 & 3,923 & 3,560 & 4,469 & 3,045 \\
\hline State budget tax arrears $1 /$ & {$[, 364$} & 1,722 & 1,401 & 2,012 & 2,657 \\
\hline Taxes on income and profits & 339 & 231 & 546 & 531 & 866 \\
\hline Personal income tax & 2 & $\ldots$ & 102 & 24 & 25 \\
\hline Profit tax & 329 & $\ldots$ & 439 & 500 & 835 \\
\hline Enterprise income tax & 7 & $\ldots$ & 5 & 6 & 6 \\
\hline Chernobyl tax & 226 & 215 & 102 & 135 & 138 \\
\hline Taxes on property & 126 & 443 & 189 & 401 & 378 \\
\hline Real estate tax & 92 & 79 & 75 & 188 & 194 \\
\hline Land tax & 34 & 364 & 113 & 214 & 184 \\
\hline Domestic taxes on goods and services & 674 & 833 & 565 & 945 & 1,276 \\
\hline Value-added tax & 531 & 546 & 456 & 857 & 1,156 \\
\hline Excises & 73 & 40 & 59 & 81 & 112 \\
\hline Fuel tax & 10 & 10 & 0 & 0 & 0 \\
\hline Naturai resource tax & 15 & 75 & 47 & 6 & 6 \\
\hline Forestry tax and other taxes & 44 & 162 & 3 & 2 & 1 \\
\hline Social Protection Fund & 960 & 1,783 & 1,841 & 2,180 & ... \\
\hline Fund for Support of Agricultural Producers & 185 & 418 & 318 & 278 & 388 \\
\hline \multicolumn{6}{|l|}{ Memorandum items: } \\
\hline Total tax arrears (in percent of GDP) & 2.1 & 2.1 & 1.0 & 0.7 & 0.1 \\
\hline Deferred taxes $2 /$ & 1 & 1,419 & 3,873 & 5,668 & 6,228 \\
\hline
\end{tabular}

Sources: Belarusian authorities; and Fund staff estimates.

1/ Data are not available for arrears on custom duties and excises on imports.

2/ Tax deferments, end-of-period outstanding stock. 
Table 24. Belarus: General Govemment Debt, 1996-2000 (Q1)

(In millions of robels, unless otherwise indicated; end-of-period)

\begin{tabular}{|c|c|c|c|c|c|}
\hline & 1996 & 1997 & 1998 & 1999 & $\frac{2000}{\mathrm{Q} 1}$ \\
\hline Total debt, net & 17,884 & 31,751 & 217,290 & 367,197 & 677,787 \\
\hline Domestic debt, net $1 /$ & 3,066 & 1,749 & $-5,064$ & 83,581 & 111,394 \\
\hline Republican government $2 /$ & 2,772 & 4,218 & -33 & 100,210 & 143,949 \\
\hline Local govermments & -896 & $-2,469$ & $-5,031$ & $-16,629$ & $-32,554$ \\
\hline Extrabudgetary accounts $3 /$ & $\ldots$ & $\ldots$ & $\ldots$ & $\ldots$ & $\ldots$ \\
\hline Budgetary organizations 4/ & $\cdots$ & $\cdots$ & $\cdots$ & $\ldots$ & ... \\
\hline Foreign debt $5 l$ & 14,818 & 30,002 & 222,354 & 283,616 & 566,393 \\
\hline \multicolumn{6}{|l|}{ Memorandtum items: } \\
\hline Domestic debt (in percent of GDP) $6 /$ & 1.7 & 0.5 & -0.8 & 2.9 & 3.8 \\
\hline Foreign debt (in millions of U.S. doliars) 5/ & 950 & 976 & 1011 & 886 & 859 \\
\hline Foreign debt (in percent of GDP) $5 /$ & 8.0 & 8.4 & 32.9 & 9.8 & 19.5 \\
\hline Official exchange rate, end-of-period (in rubels per U.S. dollar) & 16 & $31^{\circ}$ & 220 & 320 & 675 \\
\hline
\end{tabular}

Sources: Belarusian authorities; and Fund staff estimates.

1/ The data are derived from NBB balance sheets. Negative net cebt in 1998 reflects the revaluation of the government's foreign exchange credits to banks at increasingly depreciated exchange rates.

2/ Central government, including all budgetary funds.

3/ Including social funds.

4/ Cash balances at end of period.

5/ As recorded in the balance of payments under public and publicly guaranteed debt; includes IMF.

6/ Annualized GDP for Q1 2000. 
Table 25. Belarus: Monetary Survey, 1998-2000 (June)

(In millions of rubels; end-of-period)

\begin{tabular}{|c|c|c|c|c|c|c|c|}
\hline & \multirow{2}{*}{$\frac{1998}{\text { December }}$} & \multicolumn{4}{|c|}{1999} & \multicolumn{2}{|c|}{2000} \\
\hline & & March & June & September & December & March & June \\
\hline Accounting exchange rate (in rubels per U.S. dollar) $1 /$ & 220 & 236 & 259 & 290 & 320 & 435 & 675 \\
\hline Net foreign assets & 43,228 & 67,830 & 79,464 & 94,145 & 87,376 & 167,500 & 264,769 \\
\hline Net foreign assets (convertible) & 39,764 & 64,061 & 74,464 & 88,286 & 79,900 & 158,018 & 250,069 \\
\hline Foreign assets & 139,890 & 162,806 & 164,504 & 190,846 & 196,126 & 289,140 & 488,197 \\
\hline Foreign liabilities & $-100,126$ & $-98,746$ & $-90,040$ & $-102,560$ & $-116,226$ & $-131,122$ & $-238,128$ \\
\hline Net foreign assets (nonconvertible) & 3,464 & 3,769 & 5,000 & 5,859 & 7,476 & 9,482 & 14,700 \\
\hline Foreign assets & 4,681 & 4,806 & 11,759 & 8,324 & 10,045 & 19,725 & 30,043 \\
\hline Foreign liabilities & $-1,217$ & $-1,036$ & $-6,759$ & $-2,465$ & $-2,569$ & $-10,244$ & $-15,344$ \\
\hline Net domestic assets & 174,024 & 194,320 & 245,935 & 331,304 & 418,066 & 492,457 & 688,496 \\
\hline Net domestic credit & 247,452 & 283,260 & 324,208 & 428,760 & 601,732 & 776,596 & $1,033,329$ \\
\hline Net credit to general government & 49,548 & 46,224 & 43,007 & 49,218 & 148,115 & 193,181 & 241,260 \\
\hline Net claims on central government & 49,405 & 46,130 & 42,822 & 48,776 & 147,757 & 192,282 & 239,702 \\
\hline Gross credit to local government & 143 & 94 & 185 & 442 & 358 & 899 & 1,558 \\
\hline Claims on economy & 197,903 & 237,037 & 281,201 & 379,542 & 453,617 & 583,414 & 792,069 \\
\hline Claims on nonfinancial public enterprises & 84,081 & 96,263 & 107,527 & 150,235 & 170,598 & 237,409 & 340,145 \\
\hline Claims on private sector & 113,343 & 140,302 & 172,471 & 228,117 & 281,741 & 344,756 & 450,451 \\
\hline Claims on nonbank fisancial institutions & 480 & 471 & 1,203 & 1,190 & 1,278 & 1,250 & 1,473 \\
\hline Other items, net & $-73,427$ & $-88,940$ & $-78,274$ & $-97,455$ & $-183,666$ & $-284,139$ & $-344,833$ \\
\hline Capital & $-31,513$ & $-42,809$ & $-69,112$ & $-90,607$ & $-172,005$ & $-268,250$ & $-294,862$ \\
\hline Other assets, net & $-41,914$ & $-46,130$ & $-9,161$ & $-6,848$ & $-11,661$ & $-15,889$ & $-49,971$ \\
\hline Broad money & 217,252 & 262,151 & 325,398 & 425,449 & 505,442 & 659,957 & 953,265 \\
\hline Rubel broad money & 96,495 & 114,572 & 162,631 & 224,845 & 284,731 & 337,559 & 441,892 \\
\hline Currency outside banks & 27,074 & 32,014 & 55,026 & 69,881 & 86,852 & 108,244 & 157,165 \\
\hline Domestic currency deposits & 69,422 & 82,558 & 107,605 & 154,965 & 197,879 & 229,316 & 284,727 \\
\hline Foreign currency deposits & 120,757 & 147,579 & 162,767 & 200,604 & 220,711 & 322,397 & 511,373 \\
\hline
\end{tabular}

Source: National Bank of Belarus.

1/ Data have been revised backward to reflect the redenomination of the rubel on January 1,2000 which removed three zeros from the curency. 
Table 26. Belarus: Accounts of the National Bank of Belarus, 1998-2000 (June)

(In millions of rubels; end-of-period)

\begin{tabular}{|c|c|c|c|c|c|c|c|}
\hline & \multirow{2}{*}{$\frac{1998}{\text { December }}$} & \multicolumn{4}{|c|}{1999} & \multicolumn{2}{|c|}{2000} \\
\hline & & March & June & September & December & March & June \\
\hline Accounting exchange rate (in rubels per U.S. dollar) I/ & 107 & 236 & 259 & 290 & 320 & 435 & 675 \\
\hline \multicolumn{8}{|l|}{ National Bank of Belanıs } \\
\hline Net foreign assets & 5,745 & 10,863 & 11,109 & 16,389 & 16,633 & 32,287 & 68,902 \\
\hline Net foreign assets (convertible) & 5,324 & 10,447 & 10,864 & 16,380 & 15,858 & 31,744 & 65,937 \\
\hline Foreign assets & 75,863 & 80,955 & 79,621 & 89,974 & 97,502 & 128,015 & 247,576 \\
\hline Foreign liabilities & $-70,539$ & $-70,508$ & $-68,757$ & $.73,594$ & $-81,644$ & $-96,271$ & $-181,639$ \\
\hline Net foreign assets (nonconvertible) & 420 & 416 & 245 & 8 & 775 & 543 & 2,965 \\
\hline Foreign assets & 602 & 456 & 372 & 785 & 853 & 579 & 3,262 \\
\hline Foreign liabilities & -181 & -40 & -126 & -776 & -78 & -36 & -296 \\
\hline Net domestic assets & 60,637 & 69,235 & 87,130 & 122,643 & 168,186 & 193,720 & 239,717 \\
\hline Net domestic credit & 100,035 & 106,987 & 123,162 & 161,494 & 200,993 & 242,994 & 304,530 \\
\hline Net credit to general govemment & 48,441 & 54,376 & 59,762 & 66,556 & 138,683 & 170,427 & 218,676 \\
\hline Chaims on nonfinancial public enterprises & 22 & 28 & 28 & 41 & 44 & 15 & 33 \\
\hline Claims on private sector & 343 & 728 & 794 & 1,272 & 2,041 & 2,760 & 3,325 \\
\hline Claims on banks & 51,229 & 51,855 & 62,578 & 93,624 & 60,226 & 69,792 & 82,495 \\
\hline Other items, net & $-39,398$ & $-37,752$ & $-36,032$ & $-38,851$ & $-32,807$ & $-49,274$ & $-64,812$ \\
\hline Reserve money & 66,381 & 80,098 & 98,239 & 139,032 & 184,819 & 226,007 & 308,620 \\
\hline Currency issued outside banking system & 27,074 & 32,014 & 55,026 & 69,881 & 86,852 & 108,244 & 157,165 \\
\hline Due to banks & 37,855 & 46,805 & 41,796 & 66,170 & 91,979 & 109,332 & 140,581 \\
\hline Required reserves & 18,519 & 26,700 & 31,297 & 39,514 & 49,563 & 55,550 & 86,544 \\
\hline Excess reserves & 19,336 & 20,105 & 10,499 & 26,655 & 42,415 & 53,782 & 54,037 \\
\hline Deposits of other sectors (excluding central government) & 1,453 & 1,279 & 1,417 & 2,982 & 5,988 & 8,431 & 10,873 \\
\hline
\end{tabular}

Source: National Bank of Belarus.

1/ Data have been revised backward to reflect the redenomination of the rabel on January 1, 2000 which removed three zeros from the currency. 
Table 27. Belarus: Deposit Money Banks' Accounts, 1998-2000 (June) 1/

(In millions of rubels; end-of-period)

\begin{tabular}{|c|c|c|c|c|c|c|c|}
\hline & \multirow{2}{*}{$\frac{1998}{\text { December }}$} & \multicolumn{4}{|c|}{1999} & \multicolumn{2}{|c|}{2000} \\
\hline & & March & June & September & December & March & June \\
\hline Net foreign assets & 37,484 & 56,967 & 68,355 & 77,756 & 70,743 & 135,213 & 195,867 \\
\hline Net foreign assets (convertible) & 34,440 & 53,613 & 63,600 & 71,905 & 64,042 & 126,274 & 184,132 \\
\hline Assets (convertible) & 64,027 & 81,851 & 84,883 & 100,872 & 98,624 & 161,125 & 240,620 \\
\hline Liabilities (convertible) & $-29,587$ & $-28,238$ & $-21,283$ & $-28,966$ & $-34,582$ & $-34,851$ & $-56,488$ \\
\hline Net foreign assets (nonconvertible) & 3,044 & 3,353 & 4,755 & 5,851 & 6,701 & 8,939 & 11,734 \\
\hline Assets (nonconvertible) & 4,080 & 4,350 & 11,387 & 7,540 & 9,192 & 19,147 & 26,782 \\
\hline Liabilities (nonconvertible) & $-1,035$ & -997 & $-6,633$ & $-1,689$ & $-2,491$ & $-10,208$ & $-15,047$ \\
\hline Net domestic assets & 151,242 & 171,890 & 200,601 & 274,831 & 341,858 & 408,069 & 589,360 \\
\hline Net domestic credit & 185,963 & 226,089 & 278,581 & 370,567 & 499,495 & 627,951 & 866,506 \\
\hline Net credit to general government & 1,107 & $-8,153$ & $-16,755$ & $-17,338$ & 9,432 & 22,754 & 22,583 \\
\hline Net credit to central government & 965 & $-8,246$ & $-16,940$ & $-17,780$ & 9,074 & 21,855 & 21,025 \\
\hline Claims on local government & 143 & 94 & 185 & 442 & 358 & 899 & 1,558 \\
\hline Claims on nonfinancial public enterprises & 84,059 & 96,235 & 107,499 & 150,193 & 170,553 & 237,393 & 340,112 \\
\hline Claims on private sector & 112,999 & 139,574 & 171,677 & 226,845 & 279,701 & 341,996 & 447,155 \\
\hline Claims on nonbank financial institutions & 480 & 471 & 1,203 & 1,190 & 1,278 & 1,250 & 1,473 \\
\hline Net claims on the National Bank & $-12,683$ & $-2,039$ & 14,956 & 9,677 & 38,531 & 24,557 & 55,211 \\
\hline Other items, net & $-34,720$ & $-54,198$ & $-77,980$ & $-95,736$ & $-157,636$ & $-219,881$ & $-277,146$ \\
\hline Liabilities to nonfinancial institutions $2 /$ & 188,726 & 228,857 & 268,956 & 352,587 & 412,602 & 543,282 & 785,227 \\
\hline Demand deposits & 52,487 & 62,262 & 79,242 & 118,154 & 140,714 & 155,817 & 184,886 \\
\hline Time and savings deposits & 15,562 & 19,224 & 27,067 & 34,058 & 51,315 & 65,649 & 90,634 \\
\hline Foreign currency deposits & 120,678 & 147,371 & 162,646 & 200,375 & 220,572 & 321,816 & 509,707 \\
\hline
\end{tabular}

Source: National Bank of Belarus.

1/ Data have been revised backward to reflect the redenomination of the nubel on January 1,2000 which removed three zeros from the currency.

2/ Excluding central government. 
Table 28. Belarus: National Bank's Directed Credits, 1997-2000 (Q1) 1/

(In millions of rubels; end-of-period)

\begin{tabular}{|c|c|c|c|c|c|c|c|c|c|c|c|c|c|}
\hline & \multicolumn{4}{|c|}{1997} & \multicolumn{4}{|c|}{1998} & \multicolumn{4}{|c|}{1999} & \multirow{2}{*}{$\frac{2000}{Q^{1}}$} \\
\hline & Q1 & $\mathrm{Q2}$ & $Q^{3}$ & $\mathrm{Q}^{4}$ & $\mathrm{Ql}$ & $\overline{Q 2}$ & $\mathrm{Q3}^{3}$ & $Q^{4}$ & $\mathrm{Q}^{1}$ & $Q^{2}$ & $Q^{3}$ & $\overline{Q 4}$ & \\
\hline Directed credit & 5,645 & 7,202 & 12,222 & 13,724 & 17,231 & 25,027 & 29,225 & 31,392 & 31,908 & 8,263 & 38,348 & 27,695 & 27,441 \\
\hline Agriculture & 2,723 & 2,351 & 1,849 & 1,457 & 2,258 & 3,921 & 4,882 & 4,601 & 4,422 & 25 & 2,229 & 22 & 17 \\
\hline Trade & 0 & $\ldots$ & $\ldots$ & $\ldots$ & $\ldots$ & 439 & 500 & 499 & 496 & $\ldots$ & $\ldots$ & $\ldots$ & 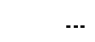 \\
\hline Industry & 276 & 468 & 3,809 & 5,947 & 5,334 & 6,458 & 5,632 & 4,206 & 2,221 & 304 & 11,947 & 3,279 & 3,059 \\
\hline Housing & 1,808 & 3,543 & 5,738 & 7,510 & 8,854 & 13,447 & 17,473 & 20,831 & 23,546 & 7,294 & 24,161 & 24,383 & 24,354 \\
\hline Other & 838 & 840 & 825 & 810 & 785 & 762 & 738 & 1,255 & 1,223 & 11 & 11 & 11 & 11 \\
\hline
\end{tabular}

Source: National Bank of Belarus.

1/ Data have been revised backward to reflect the redenomination of the rubel on January 1,2000 which removed three zeros from the currency. 
Table 29. Belarus: Composition of Bank Lending by Type of Credit and Sector, 1996-2000 (Q1)

\begin{tabular}{|c|c|c|c|c|c|c|c|c|c|c|}
\hline & 1996 & 1997 & 1998 & 1999 & 2000 & 1996 & 1997 & 1998 & 1999 & 2000 \\
\hline & \multicolumn{4}{|c|}{ (In millions of rubels) } & & \multicolumn{4}{|c|}{ (Share of total) } & \\
\hline Total bank credit & 21,489 & 48,506 & 193,300 & 442,697 & 569,333 & 100.0 & 100.0 & 100.0 & 100.0 & 100.0 \\
\hline \multicolumn{11}{|l|}{ Type of credit } \\
\hline Short-tern credit & 14,878 & 27,378 & 94,265 & 196,849 & 257,322 & 69.2 & 56.4 & 48.8 & 44.5 & 45.2 \\
\hline Industry & 6,714 & 14,458 & 42,179 & 90,435 & 107,097 & 31.2 & 29.8 & 21.8 & 20.4 & 18.8 \\
\hline Agriculture & 1,382 & 2,810 & 5,131 & 11,490 & 21,083 & 6.4 & 5.8 & 2.7 & 2.6 & 3.7 \\
\hline Construction & 493 & 617 & 1,330 & 4,408 & 6,356 & 2.3 & 1.3 & 0.7 & 1.0 & 1.1 \\
\hline Trade and catering & 2,286 & 4,341 & 22,887 & 45,155 & 64,585 & 10.6 & 8.9 & 11.8 & 10.2 & 11.3 \\
\hline Other & 4,003 & 10,773 & 22,738 & 45,362 & 58,201 & 18.6 & 22.2 & 11.8 & 10.2 & 10.2 \\
\hline Long-term credit & 6,611 & 21,128 & 99,035 & 245,848 & 312,010 & 30.8 & 43.6 & 51.2 & 55.5 & 54.8 \\
\hline Industry & 2,718 & $6,96 !$ & 48,188 & 77,825 & 133,973 & 12.7 & 14.4 & 24.9 & 17.6 & 23.5 \\
\hline Agriculture & 146 & 639 & 6,548 & 39,473 & 52,333 & 0.7 & 1.3 & 3.4 & 8.9 & 9.2 \\
\hline Housing construction & 1,322 & 8,987 & 24,861 & 86,246 & 101,957 & 6.2 & 18.5 & 12.9 & 19.5 & 17.9 \\
\hline Other & 2,424 & 4,540 & 19,438 & 42,305 & 23,747 & 11.3 & 9.4 & 10.1 & 9.6 & 4.2 \\
\hline \multicolumn{11}{|l|}{ Type of borrower } \\
\hline Short-term credit & 14,878 & 27,378 & 94,265 & 196,849 & 257,322 & 69.2 & 56.4 & 48.8 & 44.5 & 45.2 \\
\hline State enterprises & 6,770 & 11,575 & 41,922 & 66,632 & 94,837 & 31.5 & 23.9 & 21.7 & 15.1 & 16.7 \\
\hline Cooperatives & 6,306 & 13,551 & 44,921 & 115,466 & 141,518 & 29,3 & 27.9 & 23.2 & 26.1 & 24,9 \\
\hline Private sector & 862 & 1,329 & 729 & 2,997 & 2,846 & 4.0 & 2.7 & 0.4 & 0.7 & 0.5 \\
\hline Households & 444 & $86 I$ & 3,707 & 8,521 & 14,527 & 2.1 & 1.8 & 1.9 & 1.9 & 2.6 \\
\hline Other & 497 & 62 & 2,987 & 3,233 & 3,594 & 2.3 & 0.1 & 1.5 & 0.7 & 0.6 \\
\hline Long-term credit & 6,611 & 21,128 & 99,035 & 245,848 & 312,010 & 30.8 & 43.6 & 51.2 & 55.5 & 54.8 \\
\hline State enterprises & 1,650 & 5,217 & 32,488 & 83,303 & 117,628 & 7.7 & 10.8 & 16.8 & 18.8 & 20.7 \\
\hline Cooperatives & 2,454 & 4,906 & 32,328 & 75,395 & 95,156 & 11.4 & 10.1 & 16.7 & 17.0 & 16.7 \\
\hline Private sector & 701 & 1,809 & 27,891 & 76,853 & 116,905 & 3.3 & 3.7 & 14.4 & 17.4 & 20.5 \\
\hline Households & 1,246 & 8,017 & 21,256 & 58,020 & 65,730 & 5.8 & 16.5 & 11.0 & 13.1 & 11.5 \\
\hline Other & 560 & 1,179 & 6,328 & 10,297 & 11,747 & 2.6 & 2.4 . & 3.3 & 2.3 & 2.1 \\
\hline
\end{tabular}

Sources: National Bank of Belaıus; and Fund staff estimates. 
Table 30. Belatus: Auction of Securities Issued by the Ministry of Finance, 1999-2000 (Average per alction)

\begin{tabular}{|c|c|c|c|c|c|c|c|c|c|c|c|c|}
\hline & \multirow{2}{*}{$\begin{array}{l}\text { Maturity } \\
\text { (days) }\end{array}$} & \multirow{2}{*}{$\begin{array}{l}\text { Amount } \\
\text { offered }\end{array}$} & \multirow{2}{*}{$\begin{array}{l}\text { Amount } \\
\text { sold }\end{array}$} & \multirow{2}{*}{$\begin{array}{l}\text { Percent } \\
\text { sold }\end{array}$} & \multirow{2}{*}{$\begin{array}{l}\text { Revenue } \\
\text { raised }\end{array}$} & \multicolumn{3}{|c|}{ Price bids } & \multirow{2}{*}{$\begin{array}{l}\text { Weighted } \\
\text { average }\end{array}$} & \multirow{2}{*}{$\begin{array}{l}\text { Annualized yield } \\
\text { (percent) } 1 / 2 / 3 / 4 /\end{array}$} & \multirow{2}{*}{$\begin{array}{c}\text { Monthly average } \\
\text { yield (percent) } 1 / 2 / 3 / 4 i\end{array}$} & \multirow{2}{*}{$\begin{array}{l}\text { Number of } \\
\text { participants }\end{array}$} \\
\hline & & & & & & low & ctut-off & high & & & & \\
\hline \multicolumn{13}{|l|}{1999} \\
\hline \multicolumn{13}{|c|}{ Short-term secuzities } \\
\hline Jan & 316 & 0 & 7 & $\ldots$ & 5 & 0.0 & 72.8 & 0.0 & 72.8 & 43.2 & 3.6 & 1 \\
\hline Feb & 228 & 1,700 & 1,375 & 80.9 & 1,044 & 49.0 & 78.7 & 64.0 & 75.9 & 51.4 & 4.3 & 2 \\
\hline $\mathrm{Mat}$ & 325 & 4,400 & $:, 422$ & 32.3 & 830 & 46.9 & 63.5 & 83.0 & 58.4 & 82.0 & 6.8 & 4 \\
\hline$A p r$ & 160 & 5,400 & 2,127 & 39.4 & 1,574 & 50.0 & 74.1 & 82.4 & 74.0 & 89.1 & 7.4 & 6 \\
\hline May & 123 & 6,800 & 3,552 & 52.2 & 2,741 & 78.0 & 75.9 & 80.2 & 77.2 & 89.8 & 7.5 & 4 \\
\hline Jun & 102 & 8,500 & 3,450 & 40.6 & 2,758 & 75.0 & 80.4 & 79.0 & 79.9 & 90.0 & 7.5 & 12 \\
\hline Jul & 81 & 5,100 & 7,898 & 154.9 & 6,618 & 67.7 & 80.3 & 69.0 & 83.8 & 90.0 & 7.5 & 10 \\
\hline Aug & 167 & 13,900 & 10,017 & 72.1 & 7,103 & 67.7 & 71.7 & 69.3 & 70.9 & 89.9 & 7.5 & 12 \\
\hline Sep & 178 & 8,100 & 12,479 & 154.1 & 8,671 & 68.1 & 70.2 & 68.7 & 69.5 & 90.0 & 7.5 & 18 \\
\hline Oct & 177 & 7,100 & 9,575 & 134.9 & 6,680 & 68.1 & 69.7 & 68.2 & 69.8 & 89.7 & 7.5 & 17 \\
\hline Nov & 275 & 13,500 & 7,929 & 58.7 & 4,627 & 54.7 & 59.2 & 59.6 & 58.4 & 95.2 & 7.9 & 8 \\
\hline Dec & 302 & 15,000 & 11,331 & 75.5 & 7,974 & 52.6 & 56.9 & $\ldots$ & 70.4 & 74.7 & 6.2 & 5 \\
\hline \multicolumn{13}{|c|}{ Long-term securities } \\
\hline Nov & $\cdots$ & $\cdots$ & 0 & $\cdots$ & 613 & 101.7 & 107.6 & $1: 8.5$ & $\cdots$ & $\cdots$ & $\cdots$ & 1 \\
\hline \multicolumn{13}{|l|}{2000} \\
\hline \multicolumn{13}{|c|}{ Short-term securities } \\
\hline Jant & 263 & 12,900 & 8,231 & 63.8 & 4,107 & 47.7 & 50.4 & 51.6 & 49.9 & 139.7 & 11.6 & 6 \\
\hline Feb & 251 & 17,200 & 19,692 & 114.5 & 9,786 & 43.9 & 50.5 & 47.8 & 49.7 & 148.4 & 12.4 & 11 \\
\hline Mar & 198 & 18,600 & 29,184 & 156.9 & 18,360 & 48.2 & 64.5 & 80.4 & 62.9 & 113.8 & 9.5 & 22 \\
\hline \multicolumn{13}{|c|}{ Long-term securities } \\
\hline $22 \mathrm{Feb}$ & 1,004 & 4,300 & 430 & 10.0 & 430 & 100.0 & 100.0 & 100.0 & 100.0 & $\cdots$ & $\ldots$ & $\cdots$ \\
\hline
\end{tabular}

Sources: National Bank of Belarus; and Fund staff estimates.

$1 /$ Coupon rate: November 4, $1999-89.95 \%$; January 28, $2000-108.93 \%$; April 28, $2000-129.59 \%$.

2/ Coupon rate: November 8, $1999-89.92 \%$; November 25, $1999-89.99 \%$; February 25, 2000 - 130.70\%, May 25, 2000 - 121.47\%.

W Coupon rate: November 8, 1999 - 89.95\%; January 28, 2000-108.93\%; April 28, $2000-129.59 \%$.

4/ Coupon rate: February 22, 2000-127.25\%; May 22, 2000-121.47\%. 
Table 31. Belarus: Mitimum Reserve Requirements, 1995-2000

(In percent of eligible depusits; beginning of period)

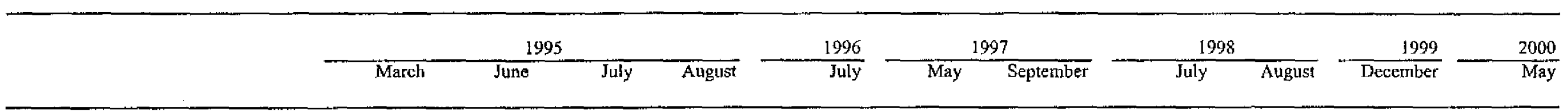

\section{Category of deposits:}

Domestic currency deposits

\begin{tabular}{|c|c|c|c|c|c|c|c|c|c|c|c|}
\hline Demand deposits & 10 & 12 & 12 & 12 & 15 & 17 & 21 & 18 & 16 & 16 & 19 \\
\hline \multicolumn{12}{|l|}{ Time deposits with naturity of: } \\
\hline less than one year & 10 & 12 & 12 & 12 & $15 / 10 / 5$ & 17 & 21 & 18 & 16 & 16 & 19 \\
\hline between one and three years & 10 & 12 & 12 & 12 & 5 & 13 & 17 & 18 & 16 & 16 & 19 \\
\hline greater than three years & 10 & 12 & 12 & 12 & 5 & 5 & 5 & 18 & 16 & 16 & 19 \\
\hline Deposits of nonresident banks & $\cdots$ & $\cdots$ & $\cdots$ & $\cdots$ & $\cdots$ & $\cdots$ & $\cdots$ & 54 & 46 & $\cdots$ & $\ldots$ \\
\hline Belarusbank & 10 & 12 & 12 & 12 & $15 / 10 / 5$ & $17 / 13 / 5$ & $21 / 17 / 5$ & 18 & 16 & $\ldots$ & $\cdots$ \\
\hline oreign exchange deposits & 5.5 & 8 & 10 & 12 & $15 / 10 / 5$ & $17 / 13 / 5$ & $21 / 17 / 5$ & 18 & 16 & 16 & 16 \\
\hline
\end{tabular}

Source: National Bank of Belarus. 


\begin{tabular}{|c|c|c|c|c|c|c|c|c|c|c|c|c|c|c|c|c|c|c|c|}
\hline & \multicolumn{13}{|c|}{1999} & \multicolumn{6}{|c|}{2000} \\
\hline & Jan & Feb & Mar & Aps & May & Jur & dull & & & Bepr & Oct & Noy & Dec & Jan & Feb & Mar & Apr & May & Jun \\
\hline \multicolumn{20}{|l|}{ Reguired reserves } \\
\hline Commercial banks, exeluding Belarustank & 0 & 0 & 0 & 0 & 0 & 0 & & & & 0 & 0 & 0 & 0 & 0 & 0 & 0 & a & 0 & 0 \\
\hline Belarusbank & 24 & 30 & 30 & 45 & 45 & 45 & & & 0 & 0 & 0 & 0 & 0 & 0 & $n$ & 0 & 0 & 0 & 0 \\
\hline Correspondent account overdrafts & ... & $\cdots$ & $\cdots$ & $\cdots$ & ". & $\cdots$ & $\cdots$ & & & ... & $\ldots$ & $\cdots$ & ".. & $\ldots$ & $\cdots$ & $\cdots$ & $\ldots$ & $\ldots$ & $\cdots$ \\
\hline General govenutreu deposils & 9 & 9 & 9 & 9 & $\cdots$ & $\ldots$ & & & & $\cdots$ & $\ldots$ & $\cdots$ & $\cdots$ & $\ldots$ & $\cdots$ & $\cdots$ & $\cdots$ & $\ldots$ & $\cdots$ \\
\hline Credit avetions 1f & $\cdots$ & $\cdots$ & 100 & 150 & $\cdots$ & $\cdots$ & .. & & ... & $\cdots$ & $\cdots$ & $\cdots$ & $\cdots$ & $\cdots$ & $\cdots$ & $\cdots$ & $\cdots$ & - & $\cdots$ \\
\hline \multirow{2}{*}{\multicolumn{20}{|c|}{$\begin{array}{l}\text { Basic Lombard rate } \\
\text { for period less than } 14 \text { days } \\
\text { for } 15 \text { to } 30 \text { days }\end{array}$}} \\
\hline & $\begin{array}{l}52 \\
54\end{array}$ & $\begin{array}{l}64 \\
66\end{array}$ & $\begin{array}{l}64 \\
66\end{array}$ & $\begin{array}{l}150 \\
160\end{array}$ & $\begin{array}{l}150 \\
160\end{array}$ & $\begin{array}{l}150 \\
160\end{array}$ & $\begin{array}{l}12 \\
12\end{array}$ & & $\begin{array}{l}20 \\
25\end{array}$ & $\begin{array}{l}120 \\
125\end{array}$ & $\begin{array}{l}120 \\
125\end{array}$ & $\begin{array}{l}120 \\
125\end{array}$ & $\begin{array}{l}120 \\
125\end{array}$ & $\begin{array}{l}150 \\
160\end{array}$ & $\begin{array}{l}150 \\
160\end{array}$ & $\begin{array}{l}180 \\
390\end{array}$ & $\begin{array}{l}180 \\
199\end{array}$ & $\begin{array}{l}160 \\
170\end{array}$ & $\begin{array}{l}160 \\
170\end{array}$ \\
\hline \multicolumn{20}{|l|}{ Refinance ratios } \\
\hline Basic rate & 48 & 60 & 60 & 90 & 90 & 90 & 9 & 0 & 90 & 90 & 90 & 90 & 110 & 120 & 175 & 150 & 110 & 100 & 90 \\
\hline Aversge cetinance rate & 10 & 10 & 10 & 11 & 11 & 21 & & 6 & 26 & 28 & 29 & 27 & 22 & 23 & 19 & 22 & 18 & 17 & $\ldots$ \\
\hline \multicolumn{20}{|l|}{ Special refinance rates } \\
\hline Belpromstroitsank & $5-62$ & $5-62$ & 584 & $5-92$ & $5-92$ & 5.92 & 5.9 & $5-9$ & 92 & 5.92 & $5-92$ & $5-92$ & $5-112$ & $5-122$ & 5.152 & $5-177$ & $5-132$ & $5-112$ & $\ldots$ \\
\hline Belagroprombank & $1-60$ & $1-60$ & $1-82$ & $1-90$ & 1.90 & $1-90$ & & $2-8$ & 89 & 2.89 & 2.89 & $2-89$ & $2-309$ & $2-119$ & 2-149 & $2-174$ & $2-129$ & $2-309$ & $\ldots$ \\
\hline Individual fantuers & $1-30$ & 1.30 & $1-41$ & $1-45$ & 1.45 & 1.45 & & $\ldots$ & $\ldots$ & $\ldots$ & $\ldots$ & $\ldots$ & $\ldots$ & $\ldots$ & ... & $\ldots$ & $\ldots$ & $\ldots$ & ... \\
\hline Housing & $2-6.5$ & $2-6.5$ & $2-6.5$ & $2-6.5$ & $2-6.5$ & $2-6.5$ & & 2 & 2 & 2 & 2 & 2 & 2 & 2 & 2 & 2 & 2 & 2 & $\ldots$ \\
\hline Credit to gavernment $y$ & $0 / 6.5 / 48$ & $0 / 6.5 / 60$ & $0 / 6.5 / 60$ & $0 / 6.5 / 9000 t$ & $.5 / 9 i \mathrm{i}$ & $6.5 / 90$ & 6.5190 & 06.549 & $0 / 6.5 / 90$ & & 5,900 & $6.5 / 90$ & $0,66.5 / 110$ & $0 / 6.5 / 120$ & $0 / 6.5 / 150$ & $06.5 / 173$ & $0 / 6.5 / 450$ & $9 / 6.5 / 110$ & $\ldots$ \\
\hline
\end{tabular}

Source: National Bank of Belants.

1/ Calculated at the average rate of the last Lambard atction of the previous month.

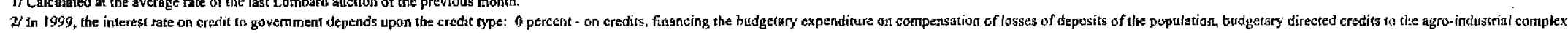
and bousing construction; the refinance rate - on financing the l999 budget deficit; 6.5 percent - on deficit financing of the previaus years. 
Table 33. Belatus: Interest Rates on Bank Deposits, 1999-2000 (May) (In percent per annum)

\begin{tabular}{|c|c|c|c|c|c|c|c|c|c|c|c|c|c|c|c|c|c|}
\hline & \multicolumn{12}{|c|}{1999} & \multicolumn{5}{|c|}{2000} \\
\hline & Jam & Feb & Mat & Apr & May & Juท & Jul & Aug & Sep & Oet & Nay & Dec & $\operatorname{Jan}$ & Feb & Mar & Apr & May \\
\hline Deposits with commercial banks 1 / & 14.2 & 17.7 & 21.4 & 23.5 & 24.1 & 26.4 & 26.6 & 26.2 & 26.1 & 25.5 & 25.5 & 28.4 & 32.9 & 36.1 & 38.4 & $\$ 3.1$ & 41,6 \\
\hline Of which : Belanssbank & 10.6 & 11.8 & 14.0 & 18.7 & 19.3 & 26.5 & 25.5 & 24.6 & 22.5 & 20.4 & 21.4 & 25 & 26.0 & 27.8 & 28.8 & 35.6 & 33.2 \\
\hline Belpromstrotbank & 8.9 & 10.9 & 17.7 & 19.8 & 17.9 & 19.1 & 22.5 & 23 & 24,4 & 22.9 & 21.5 & 20 & 22.1 & 28.6 & 30,0 & 40.2 & 40.6 \\
\hline Belagroprombank & 19.2 & 21.7 & 22.8 & 23.5 & $2: 4$ & 19 & 18.2 & 23.6 & 28.1 & 31.8 & 31.3 & 34 & 36.9 & 38.6 & 40.0 & 38.8 & 39.5 \\
\hline New deposits 27 & 41.9 & 43.6 & 550 & 64.2 & 58.4 & 67.0 & 64.0 & 61.9 & 52.7 & 58.6 & 59.3 & 71.6 & 86.9 & 103.4 & 88.1 & 96.9 & 91.9 \\
\hline Up to 1 month & 45.2 & 47.3 & 63.0 & 75.4 & 71.0 & 80.9 & 78.2 & 71.7 & 58.6 & 68.1 & 66.7 & 79.8 & 99.1 & 113.5 & 87,0 & 103.4 & 92.8 \\
\hline I to 3 months & 46.5 & 49.9 & 64.0 & 70.1 & 69.7 & 71.5 & 73.3 & 73.0 & 78.5 & 68.3 & 66.5 & 81.1 & 90.4 & II 2.6 & 111.2 & 108.5 & 1100 \\
\hline 3106 manths & 49.8 & $\$ 2.4$ & 56.1 & 67.9 & 70.0 & 71.5 & 66.1 & 67.5 & 70.3 & 71.1 & 81.2 & 87.3 & 94.9 & 112.5 & 117.6 & 107.7 & [1 13,4 \\
\hline 6 to 12 montths & 45.6 & 52.5 & 69.1 & 72.3 & 64.2 & 63.9 & 72.2 & 71.4 & 59.1 & 61.8 & 54.0 & 75.0 & 83.2 & 113.9 & 75.8 & 80.4 & 91.7 \\
\hline 1 to 3 years & 51.4 & $\$ 8.2$ & 63.7 & 68.6 & 69.2 & 68.0 & 72.0 & 61.8 & 72.5 & 80.4 & 74.9 & 87.0 & 112.0 & 123.8 & 137.3 & 141.2 & 138.4 \\
\hline More than 3 years & 57.0 & 57.0 & 66.7 & 44.6 & 75.6 & 70.1 & 13.2 & 75.0 & 75.0 & 88,7 & 99.8 & $\mathrm{~J} 19.9$ & 120.0 & 139.4 & 169.9 & 175.5 & 152.4 \\
\hline
\end{tabular}

Source: National Bank of Belanus.

1/ Deposits received between the fwenty-fitst day of the preceeding month and the twenticth day of the curent manth.

zl Deposits received within the current manth. The interest rates for deposits with up to one month tnaturity are the average ratio on deposits from ejglt days to one month; the nverall average includes the rates on deposits for one week or less 
Table 34. Belarus: interest Rates on Bank Credit, 1999-2000 (May)

([n percent per annum; period average)

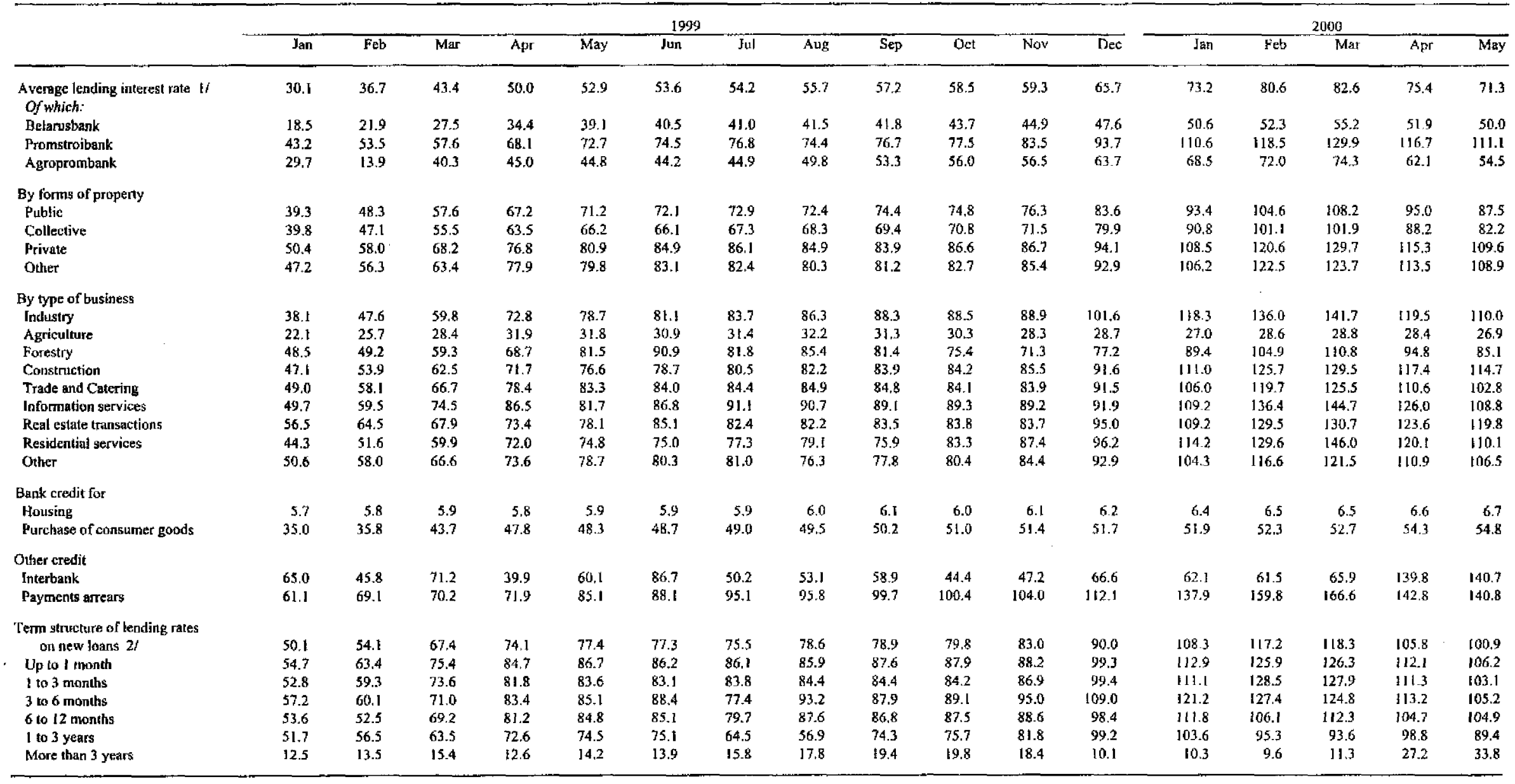

Source: National Bank of Belarus.

I/ Interest rates on credits granted between the twenty-first day of the preceeding and the fwenticth day of the current monith.

2/ Itterest rates for maturities up to one motth are the average rates on credits from eight days to one month; the overall average includes the sates on credits for one week or less. 
Table 35. Belarus: Interest Rates on New Foreign Exchange Credits and Deposits, 1999-2000 (May)

(In percent per annum)

\begin{tabular}{|c|c|c|c|c|c|c|c|c|c|c|c|c|c|c|c|c|c|}
\hline & \multicolumn{12}{|c|}{1999} & \multicolumn{5}{|c|}{2000} \\
\hline & Jan & Feb & Mar & Apr & May & Jun & Jul & Aug & Sep & Oet & Nov & $\overline{\mathrm{Dec}}$ & $\operatorname{Jan}$ & Feb & Mar & $\mathrm{Apr}$ & May \\
\hline Credits I/ & 19.8 & 19.5 & 17.5 & 19.1 & 18.5 & 18.7 & $\uparrow 7.8$ & 17.9 & 15.3 & 15.3 & 17.5 & 14.6 & 15.1 & 17.0 & 16.4 & 17.3 & 15.8 \\
\hline Up to 1 month & 21.0 & 20.8 & 18.7 & 17.3 & 24.5 & 25.6 & 27.2 & 18.7 & 15.4 & 25.2 & 19.3 & 15.9 & 17.9 & 20.7 & 16.1 & 20.0 & 18.0 \\
\hline 1 to 3 months & 21.5 & 20.5 & 23.7 & 22.1 & 20.4 & 19.3 & 18.8 & 20.5 & 18.1 & 15.7 & 19.0 & 18.0 & 18.2 & 16.9 & 15.9 & 16.3 & 14.8 \\
\hline 3 to 6 months & 22.7 & 20.3 & 20.5 & 21.3 & 18.8 & 18.1 & 17.8 & 9.8 & 16.7 & 18.8 & 14.5 & 17.3 & 18.3 & 18.9 & 19,0 & 18.5 & 14.7 \\
\hline 6 to 12 months & 2.1 .6 & 21.9 & 15.2 & 18.6 & 18.4 & 18.4 & 17.3 & 19.2 & 19.3 & 18.8 & 18.6 & 18.1 & 11.2 & 17.3 & 17.1 & 17.9 & 17.0 \\
\hline 1 to 3 years & 16.7 & 15.5 & 17.6 & 20.1 & 21.3 & 19.2 & 15.2 & 18.0 & 12.1 & 13.3 & 15.6 & 11.0 & 15.3 & 15.6 & 14.9 & 15.6 & 15.9 \\
\hline More than 3 years & 13.1 & 13.2 & 12.2 & 14.3 & 13.9 & 14.9 & 14.6 & 15.0 & 15.2 & 15.8 & 16.2 & 16.0 & 15.2 & 16.2 & 17.0 & 15.8 & 16.7 \\
\hline Deposits 1/ & 10.2 & 12.3 & 10.7 & 11.9 & 12.5 & 10.1 & 8.8 & 8.7 & 9.1 & 8.6 & 9.3 & 8.0 & 9.1 & 9.4 & 9.8 & 10.0 & 10.1 \\
\hline Up to 1 month & 5.3 & 8.5 & 5.8 & 8.0 & 9.2 & 5.9 & 4.7 & 8.5 & 4.4 & 5.1 & 9.4 & 5.4 & 5.8 & 9.7 & 7.5 & 11.0 & 11.7 \\
\hline 1 to 3 months & 11.6 & 11.3 & 10.5 & 11.1 & 10.2 & 9.2 & 10.4 & 6.3 & 8.7 & 9.6 & 6.1 & 6.5 & 7.3 & 7.8 & 8.6 & 8.5 & 10.1 \\
\hline 3 to 6 months & $\$ 1.3$ & 11.7 & 11.5 & 10.9 & 11.3 & 11.5 & 10.7 & 10.0 & 10.1 & 9.3 & 9.8 & 9.5 & 10.9 & 10.4 & 10.2 & 10.1 & 9.7 \\
\hline 6 to 12 months & 13.7 & 14.8 & 12.5 & 12.7 & 11.9 & 12.0 & 11.8 & 11.1 & 10.9 & 10.9 & 11.9 & 10.8 & 10.8 & 10.9 & 10.7 & 9.6 & 10.0 \\
\hline 1 to 3 years & 11.5 & 13.5 & 12.6 & 17.0 & 23.1 & 12.8 & 12.8 & 11.7 & 12.0 & 11.8 & 11.5 & 10.5 & 11.4 & 9.4 & 9.9 & 12.6 & 12.2 \\
\hline More than 3 years & 15.9 & 12.3 & 8.3 & 16.4 & 15.1 & 14.2 & 15.3 & 15.3 & 15.6 & 15.0 & 15.3 & 14.3 & 14.1 & 13.9 & 12.8 & 14.4 & 14.5 \\
\hline
\end{tabular}

Source: National Bank of Belarus.

1/ Rates are on loans granted and deposits received between the twenty-first day of the preceeding and the twentieth day of the current month. 
Table 36. Belarus: Structural Characteristics of the Banking Sector, 1997-2000 (March) (In percent of total; end-of-period)

\begin{tabular}{|c|c|c|c|c|c|c|}
\hline & $\begin{array}{l}\text { Former } \\
\text { specialized } \\
\text { banks }\end{array}$ & $\begin{array}{c}\text { Belagroprom- } \\
\text { bank }\end{array}$ & $\begin{array}{l}\text { Belpromstroi- } \\
\text { bank }\end{array}$ & $\begin{array}{l}\text { Belvnesheconom- } \\
\text { bark }\end{array}$ & $\begin{array}{c}\text { Belarus } \\
\text { bank }\end{array}$ & $\begin{array}{c}\text { Other } \\
\text { commercial } \\
\text { banks }\end{array}$ \\
\hline \multicolumn{7}{|l|}{ Paid-in capital } \\
\hline 1997 & 46.8 & 3.0 & 3.3 & 13.7 & 26.8 & 53.2 \\
\hline 1998 & 30.2 & 0.0 & 7.2 & 12.0 & 11.0 & 69.8 \\
\hline 1999 & 81.7 & 29.6 & 8.2 & 3.0 & 40.9 & 18.3 \\
\hline $2000($ March $)$ & 81.7 & 32.0 & 8.3 & 2.8 & 38.6 & 18.3 \\
\hline \multicolumn{7}{|c|}{ Domestic currency loans } \\
\hline 1997 & 84.8 & 34.2 & 11.8 & 2.0 & 36.8 & 15.2 \\
\hline 1998 & 82.2 & 29.6 & 9.7 & 1.9 & 41.0 & 17.8 \\
\hline 1999 & 81.7 & 29.6 & 8.2 & 3.0 & 40.9 & 18.3 \\
\hline 2000 (March) & 81.7 & 32.0 & 8.3 & 2.8 & 38.6 & 18.3 \\
\hline \multicolumn{7}{|c|}{ Domestic currency deposits } \\
\hline 1997 & 70.3 & 13.5 & 18.6 & 3.0 & 35.2 & 29.7 \\
\hline 1998 & 70.4 & 11.5 & 26.3 & 2.7 & 29.9 & 29.6 \\
\hline 1999 & 68.4 & 14.2 & 18.0 & 2.5 & 33.7 & 31.6 \\
\hline 2000 (March) & 70.6 & 17.1 & 15.6 & 2.6 & 35.3 & 29.4 \\
\hline \multicolumn{7}{|c|}{ Refinancing from NBB } \\
\hline 1997 & 99.7 & 40.4 & 0.8 & 0.1 & 58.4 & 0.3 \\
\hline 1998 & 99.8 & 37.0 & 1.0 & 0.0 & 61.8 & 0.2 \\
\hline 1999 & 90.7 & 40.6 & 0.9 & 0.1 & 49.1 & 9.3 \\
\hline 2000 (March) & 95.1 & 41.2 & 0.9 & 0.1 & 52.9 & 4.9 \\
\hline
\end{tabular}

Source: National Bank of Belarus. 
Table 37. Belarus: Commercial Banks, Selected Indicators, 1996-2000 (March)

(In millions of rubels, unless otherwise indicated; end-of-period)

\begin{tabular}{|c|c|c|c|c|c|}
\hline & 1996 & 1997 & 1998 & 1999 & $\frac{2000}{\text { March }}$ \\
\hline Capital fund & $3,335.4$ & $5,402.2$ & $20,526.0$ & $133,434.1$ & $148,910.5$ \\
\hline Authorized funds & $3,202.2$ & $5,608.1$ & $4,841.7$ & $\ldots$ & $\ldots$ \\
\hline Unrealized exchange rate gains & 219.6 & 800.2 & $11,941.2$ & $\ldots$ & $\cdots$ \\
\hline Retained profits & 371.2 & 370.2 & 765.4 & $\ldots$ & $\ldots$ \\
\hline Reevaiuation fund & 788.8 & $1,521.4$ & $2,796.6$ & $\ldots$ & $\ldots$ \\
\hline Idle resources & 16.7 & $\ldots$ & 0.0 & $\ldots$ & $\ldots$ \\
\hline Main funds amortization & 600.0 & $1,038.5$ & $\ldots$ & $\ldots$ & $\ldots$ \\
\hline Long-term capital investments & 24.6 & 47.3 & $\ldots$ & $\ldots$ & $\ldots$ \\
\hline Nonmaterial assets & 33.0 & 73.1 & 138.5 & $\ldots$ & $\ldots$ \\
\hline Reserves of nonconvertible currencies & $\ldots$ & $\ldots$ & $\ldots$ & $\ldots$ & $\cdots$ \\
\hline Shortfall in provisions against unrealized losses & 542.3 & $1,731.4$ & $2,137.0$ & $\cdots$ & $\cdots$ \\
\hline Shares purchased by banks & 29.7 & 7.4 & 14.5 & & \\
\hline \multicolumn{6}{|l|}{ Assets } \\
\hline Balance shcet assets & $77,833.6$ & $169,055.0$ & $580,532.0$ & $800,992.1$ & $1,072,990.7$ \\
\hline Risk weighted assets & $20,919.0$ & 44.767 .5 & $181,208.1$ & $423,876.2$ & $674,3: 4.7$ \\
\hline (In percent of balance sheet assets) & 26.9 & 26.5 & 31.2 & 52.9 & 62.8 \\
\hline Capital adequacy ratio & 15.9 & 12.1 & 11.3 & 31.5 & 22.1 \\
\hline Gross credit & $26,263.1$ & $61,407.4$ & $241,607.5$ & $524,344,4$ & $680,377.3$ \\
\hline (In percent of assets) & 33.7 & 36.3 & 41.5 & 65.5 & 63.4 \\
\hline Arrears to banks & $2,933.2$ & $6,496.9$ & $29,514.8$ & $53,193.5$ & $71,026.3$ \\
\hline (In percent of gross credit) & 11.2 & 10.6 & 12.2 & 10.1 & 10.4 \\
\hline (In percent of capital fund) & 87.9 & 120.3 & 143.8 & 39.9 & 47.7 \\
\hline Principal arrears & $2,626.9$ & $6,047.2$ & $27,563.6$ & $49,437.4$ & $65,348.2$ \\
\hline (In percent of gross credit) & 10.0 & 9.9 & 11.4 & 9.4 & 9.6 \\
\hline Interest arrears & 306.3 & 449.7 & $1,951.2$ & $3,756.1$ & $5,678.1$ \\
\hline (In percent of gross credit) & 1.2 & 0.7 & 0.8 & 0.7 & 0.8 \\
\hline Reguired provisions against bad loans & $2,058.8$ & $4,228.6$ & $23,961.9$ & $42,563.3$ & \\
\hline (In percent of total loans) & 8.0 & 6.9 & 9.9 & 8.1 & $\ldots$ \\
\hline (In percent of capital fund) & 61.7 & 78.3 & 116.7 & 31.9 & $\ldots$ \\
\hline Actual provisions against bad loans & $1,548.4$ & $2,484.0$ & $12,106.2$ & $30,617.5$ & ... \\
\hline (In percent of total loans) & 6.0 & 4.1 & 5.0 & 5.8 & 0.0 \\
\hline (In percent of capital fund) & 46.4 & 460 & 59.0 & 22.9 & $\ldots$ \\
\hline Profits & 676.9 & 743.3 & $2,102.6$ & $9,223.6$ & $4,903.7$ \\
\hline (In percent of gross credit) & 2.6 & 1.2 & 0.9 & 1.8 & 0.7 \\
\hline \multicolumn{6}{|l|}{ Memorandum items: } \\
\hline \multicolumn{6}{|l|}{ Liquidity ratio } \\
\hline Requirement & 1.0 & 1.0 & 1.0 & 1.0 & 1.0 \\
\hline Unweighted average & 3.0 & 2.4 & 3.3 & 1.5 & 1.2 \\
\hline
\end{tabular}

Source: National Bank of Belarus.

1/ Including waivers on compliance with bad loan provisioning.

2/ Excluding waivers on compliance with bad loan ptovisioning. 
Table 38. Belarus: Six Largest Commercial Banks, Selected Indicators, 1996-2000 (March) U/ (In milhions of rubels, unless otherwise indicated; end-of-period)

\begin{tabular}{|c|c|c|c|c|c|c|}
\hline & \multirow{2}{*}{1996} & \multirow{2}{*}{1997} & \multicolumn{2}{|c|}{1998} & 1999 & March 2000 \\
\hline & & & Unadjusted 2 & Adjusted $\overline{3} /$ & Unadjusted $2 /$ Adjusted $3 /$ & Unadjusted 2/ Adjusted $3 /$ \\
\hline Capial fund & $2,196.2$ & $3,208.2$ & $8,114.6$ & $\overline{1,157.3}$ & $108,416.2$ & $114,522.7$ \\
\hline (In percent of ail banks' sapitat fund) & 65.8 & 59.4 & 39.5 & 10.7 & 81.3 & 76.9 \\
\hline \multicolumn{7}{|l|}{ Assets } \\
\hline Balance sheet assets & $67,571,4$ & $151,136.7$ & $494,923.3$ & $494,923.3$ & 667,3512 & $892,203.1$ \\
\hline (In percent of all banks' assets) & 86.8 & 89.0 & 85.3 & 85.3 & 83.3 & 83.2 \\
\hline Rjsk-weighted assets & $18,039.1$ & $39,524,4$ & $142,528.2$ & $142,528.2$ & $344,802.7$ & $561,434.5$ \\
\hline (In percent of all banks' assets) & 85.8 & 88.3 & 78.7 & 78.7 & 81.3 & 83.3 \\
\hline (In percent of balance sheet assets) & 26.7 & 26.2 & 28.8 & 28.8 & 51.7 & 62.9 \\
\hline Capital adequacy ratio & 12.2 & 8.1 & 7.7 & 0.8 & 0.3 & 0.2 \\
\hline Gross credit & $22,755.5$ & $54,454.4$ & $201,147.6$ & $201,147.6$ & $469,124.9$ & $606,553.4$ \\
\hline (In percent of total banks' gross credit) & 86.6 & 88.2 & 83.3 & 33.3 & 89.5 & 0.9 \\
\hline (In percent of assets) & 33.7 & 36.0 & 40.6 & 40.6 & 70.3 & 0.7 \\
\hline Artears to banks & $2,528.6$ & $6,107.4$ & $26,005.3$ & $26,003.3$ & $47,498.2$ & $63,332.2$ \\
\hline (In percent of total arrears) & 86.2 & 92.0 & 88.1 & 88.1 & 89.3 & 88.8 \\
\hline (In percent of gross credit) & 11.1 & 11.2 & 12,9 & 12.9 & 10.1 & 10.4 \\
\hline (In percent of capital fund) & Il5.1 & $\$ 90.4$ & 320.5 & $2,259.0$ & 43.8 & 55.3 \\
\hline Principal arrears & $2,261.5$ & $5,696.0$ & $24,184.1$ & $24,184.1$ & $43,914.2$ & $57,957.0$ \\
\hline (In percent of gross credit) & 9.9 & 10.5 & 12.0 & 12.0 & 9.4 & 9.6 \\
\hline Interest arrears & 267.1 & 411.4 & $1,819.2$ & 1.819 .2 & $3,584.0$ & $5,375.2$ \\
\hline (In percent of gross credit) & 1.2 & 0.8 & 0.9 & 0.9 & 0.8 & 0.9 \\
\hline Required provisions against bad loans & $1,845.0$ & $3,978.6$ & $21,636.3$ & $21,636.3$ & $37,274.8$ & $49,777.5$ \\
\hline (In percent of tolal loans) & 7.2 & 7.4 & 10.8 & 10.8 & 7.9 & 8.2 \\
\hline (In pereent of capital fund) & 84,0 & 124,0 & 266.6 & $1,879,6$ & 34.3 & 43.5 \\
\hline Actual provisions against bad loans & $1,326.0$ & $2,298.1$ & $11,540.5$ & $11,140.5$ & $28,139.5$ & $41,594.6$ \\
\hline (In percent of total loans) & 5.1 & 4.3 & 5.5 & 5.5 & 6.0 & 6.8 \\
\hline (In percent of capital fund) & 60.4 & 71.6 & 137.3 & 112.1 & 26.0 & 36.3 \\
\hline Profits & 559.1 & 569.6 & $1,248.0$ & $1,248.0$ & $6,879.2$ & $3,871.9$ \\
\hline (In percent of total profits) & 82.6 & 76.6 & 59.4 & 59.4 & 74.6 & 79.0 \\
\hline (In percent of gross credit) & 2.5 & l.1 & 0.6 & 0.6 & 1.5 & 0.6 \\
\hline \multicolumn{7}{|l|}{ Memorandum item: } \\
\hline Liquidity ratio & 1.4 & 1.2 & 16 & & 1.5 & 1.3 \\
\hline
\end{tabular}

Source: National Bank of Belarus.

1/ Inciudes Belarusbank, Promstroibank, Agroprombank, Businessbank, Priorbank, and Vnesheconombank.

2 Including waivers on compliance with bad loan provisioning.

$3 i$ Excluding wajvers on compliance with bad loan provisioning. 
Table 39. Belarus: Commercial Banks and Branches of Foreign Banks

(As of May 1, 2000)

\begin{tabular}{|c|c|c|c|c|}
\hline & & $\begin{array}{c}\text { Date of } \\
\text { establishment }\end{array}$ & $\begin{array}{l}\text { Number } \\
\text { of branches }\end{array}$ & $\begin{array}{c}\text { Total assets } \\
\text { (in millions of rubels) }\end{array}$ \\
\hline 1 & Belagrobank & Sep 3,1991 & 132 & 160,763 \\
\hline 2 & Belpromstroibank & $\operatorname{Dec} 28,1991$ & 60 & 112,101 \\
\hline 3 & Belarusbank & Oct 27,1995 & 175 & 421,228 \\
\hline 4 & Belbusinessbank & Sep 1, 1992 & 45 & 58,868 \\
\hline 5 & Belbank Razvitiye & Nov 5,1993 & 7 & 17,743 \\
\hline 6 & Priorbank & Jul 12, 1991 & 29 & 84,988 \\
\hline 7 & Belkombank & May 7,1991 & 12 & 6,429 \\
\hline 8 & Belvnesheconombank & Dec 12,1991 & 23 & 96,318 \\
\hline 9 & Poisk & May 15, 1991 & 17 & 9,640 \\
\hline 10 & Belnarodni & Apr 16, 1992 & $\ldots$ & 3,665 \\
\hline 11 & Belarus Industrial Bank & Oct 30,1991 & 5 & 3,425 \\
\hline 12 & Belgazprombank & Aug 19, 1991 & 5 & 13,505 \\
\hline 13 & Absolutbank & $\operatorname{Dec} 29,1993$ & 1 & 1,562 \\
\hline 14 & Belkoopbank & Feb 20, 1992 & 12 & 1,294 \\
\hline 15 & Gem-Bank & Aug 26, 1991 & $\ldots$ & 8,879 \\
\hline 16 & Belbirzhevoibank & Oct 7,1992 & 7 & 18,475 \\
\hline 17 & Minsk Kompleksbank & Feb $2 !, 1994$ & $\ldots$ & 34,323 \\
\hline 18 & Bank Reconverzi i Razvitiya & Feb 22, 1994 & $\ldots$ & 3,120 \\
\hline 19 & Minsk Tranzitnibank & Mar 14, 1994 & 5 & 4,579 \\
\hline 20 & Novokom & Apr 1,1994 & $\ldots$ & 1,556 \\
\hline 21 & Belbaltiya & Jun 30,1994 & 1 & 13,403 \\
\hline 22 & Tekhnobank & Aug 5, 1994 & 4 & 9,646 \\
\hline 23 & Zolotoi Taler & Oct 5,1994 & $\ldots$ & 4,780 \\
\hline 24 & Infobank & Nov 11, 1994 & 3 & 11,028 \\
\hline 25 & Mosbusinessbank, Minsk branch & Dec 28, 1994 & $\ldots$ & 6,772 \\
\hline 26 & Slavneftebank & Oct 7,1996 & 1 & 17,492 \\
\hline 27 & Mezhtorgbank & Jan. 28, 1999 & $\ldots$ & 5,032 \\
\hline 28 & Moscow-Minsk & Apr 7,2000 & $\ldots$ & 2,048 \\
\hline
\end{tabular}

Sources: National Bank of Belarus; and Fund staff estimates. 
Table 40. Belarus: Official Exchange Rates, 1996-2000 (Q1)

\begin{tabular}{|c|c|c|c|c|c|c|c|c|c|}
\hline & \multirow[t]{2}{*}{1996} & \multirow[t]{2}{*}{1997} & \multirow[t]{2}{*}{1998} & \multirow[t]{2}{*}{1999} & \multicolumn{4}{|c|}{1999} & \multirow{2}{*}{$\frac{2000}{Q 1}$} \\
\hline & & & & & Q1 & $\mathrm{Q} 2$ & Q3 & $\overline{Q 4}$ & \\
\hline \multicolumn{10}{|c|}{ Nominal exchange rate } \\
\hline \multicolumn{10}{|c|}{ Rubel per U.S. dollar $1 /$} \\
\hline Average & 13 & 26 & 46 & 236 & 172 & 248 & 274 & 250 & 382 \\
\hline End-of-period & 16 & 31 & 107 & 319 & 236 & 259 & 290 & 320 & 435 \\
\hline \multicolumn{10}{|c|}{ Rubel per Russian ruble } \\
\hline Average & 3 & 5 & 5 & 10 & 7 & 10 & 11 & 12 & 14 \\
\hline End-of-period & 3 & 5 & 5 & 12 & 10 & 11 & 12 & 12 & 15 \\
\hline \multicolumn{10}{|c|}{ Real exchange rate index (Dec. $1990=100$ ) $2 /$} \\
\hline \multicolumn{10}{|c|}{ Rubel per U.S. dollar } \\
\hline Average & 58 & 54 & 66 & 88 & 79 & 88 & 88 & 96 & 105 \\
\hline End-of-period & 56 & 54 & 57 & 103 & 85 & 87 & 89 & 103 & 102 \\
\hline \multicolumn{10}{|c|}{ Rubel per Russian ruble } \\
\hline Average & 49 & 46 & 62 & 89 & 82 & 90 & 88 & 95 & 102 \\
\hline End-of-period & 48 & 47 & 59 & 100 & 88 & 89 & 89 & 100 & 98 \\
\hline
\end{tabular}

Sources: National Bank of Belarus; and Fund staff estimates.

1/ Data have been revised backward to reflect the redenomination of the rubel on January 1,2000 which removed three zeros from the currency.

2/ An increase in the index indicates a real appreciation, 
Table 41. Belarus: Direction of Trade: Exports and Imports, 1995-99

(In millions of U.S. dollars, unless otherwise indicated)

\begin{tabular}{|c|c|c|c|c|c|}
\hline & 1995 & 1996 & 1997 & 1998 & 1999 \\
\hline Total exports & 4,803 & 5,652 & 7,301 & 7,070 & 5,909 \\
\hline $\begin{array}{l}\text { CIS exports } \\
\text { Of which: }\end{array}$ & 3,027 & 3,764 & 5,379 & 5,160 & 3,622 \\
\hline Russia & 2,185 & 3,024 & 4,730 & 4,608 & 3,222 \\
\hline Ukraine & 607 & 478 & 425 & 387 & 281 \\
\hline Kazakhstan & 76 & 85 & 53 & 48 & 28 \\
\hline Other countries & 153 & 177 & 121 & 117 & 91 \\
\hline Non-CIS exports & 1,776 & 1,888 & 1,922 & 1,910 & 2,287 \\
\hline Germany & 268 & 198 & 217 & 200 & 215 \\
\hline Poland & 271 & 338 & 245 & 185 & 208 \\
\hline Other countries & 1,180 & 1,268 & 1,367 & 1,422 & 1,864 \\
\hline Total imports & 5,564 & 6,939 & 8,689 & 8,549 & 6,674 \\
\hline $\begin{array}{l}\text { CIS imports } \\
\text { Of which: }\end{array}$ & 3,677 & 4,570 & 5,817 & 5,554 & 4,289 \\
\hline Russia & 1,965 & 3,522 & 4,673 & 4,670 & 3,767 \\
\hline Ukraine & 509 & 889 & 968 & 740 & 416 \\
\hline Kazakhstan & 56 & 59 & 39 & 36 & 13 \\
\hline Other countries & 87 & 100 & 137 & 108 & 93 \\
\hline Non-CIS imports & 1,887 & 2,369 & 2,872 & 2,995 & 2,385 \\
\hline Germany & 424 & 601 & 691 & 758 & 693 \\
\hline Poland & 197 & 195 & 250 & 283 & 213 \\
\hline Other countries & 1,168 & 1,422 & 1,793 & 1,829 & 1,479 \\
\hline \multicolumn{6}{|l|}{ Memorandum items: } \\
\hline Share of CIS exports to total exports & 62 & 67 & 74 & 73 & 61 \\
\hline Russia & 45 & 54 & 65 & 65 & 55 \\
\hline Share of CIS imports to total imports & 66 & 66 & 67 & 65 & 64 \\
\hline Russia & 35 & 51 & 54 & 55 & 56 \\
\hline
\end{tabular}

Source: Ministry of Statistics and Analysis; and Fund staff estimates. 
Table 42. Belarus: Extemal Trade in Goods by Economic Branches, 1996-99 (In billions of nabels)

\begin{tabular}{|c|c|c|c|c|c|c|c|c|c|c|c|c|}
\hline & \multicolumn{3}{|c|}{1996} & \multicolumn{3}{|c|}{1997} & \multicolumn{3}{|c|}{1998} & \multicolumn{3}{|c|}{1999} \\
\hline & Imports & Exports & Trade batance & Imports & Expotts & Trade balance & Impors & Exponts & Trade balance & lmpors & Exports & Trade balanec \\
\hline Total & 92,851 & 75,142 & $-17,708$ & 230,294 & 193,084 & $-37,210$ & 428,703 & 364,260 & $-64,443$ & $1,776,653$ & $1,574,700$ & $-201,953$ \\
\hline CIS & 61,430 & 49,777 & $-1], 653$ & 153,830 & 142,583 & $-11,247$ & 274,422 & 255,664 & $-18,758$ & $1,144,48 t$ & 968,077 & $-176,405$ \\
\hline Non-CIS & 31,421 & 15,368 & $-16,053$ & 76,463 & 50,501 & $-25,962$ & 154,281 & 108,596 & $-4 \$, 685$ & 632,172 & 606,623 & $-25,549$ \\
\hline Industry & 88,229 & 73,633 & $.14,597$ & 221,827 & 189,810 & $-32,017$ & 410,697 & 356,406 & $-54,291$ & $1,680,32 \mathrm{t}$ & $1,535,208$ & $-145,113$ \\
\hline CAS & 58,036 & 45,368 & $-12,668$ & 148,830 & $140,2,15$ & $-8,616$ & 261,910 & 249,864 & $-12,046$ & $1,078,346$ & 931,395 & $-[46,95 !$ \\
\hline Non-CIS & 30,199 & 24,565 & $-5,634$ & 72,997 & 49,596 & $-23,401$ & 148,787 & 106,542 & $.42,245$ & 601,975 & 603,813 & 1,838 \\
\hline Power genteration & 2,415 & 4 & $-2,411$ & 4,515 & 70 & $-4,445$ & 11,365 & 6 & $-11,358$ & 35,970 & 30 & $-35,940$ \\
\hline CIS & 1,556 & 4 & $-1,552$ & 3,192 & 1 & $-3,191$ & 5,719 & 6 & $-5,713$ & 30,472 & 29 & $-30,443$ \\
\hline Non-CIS & 857 & 0 & -857 & 1,322 & 69 & $-1,254$ & 5,646 & 0 & $-5,64 \$$ & 5,498 & 1 & $-5,497$ \\
\hline Refineries products & 25,545 & 8,843 & $-16,702$ & 55,299 & 15,813 & $-39,486$ & 85,872 & $18,23 !$ & $-67,64 !$ & 32,660 & 132,129 & 99.470 \\
\hline CIS & 25,262 & 5,545 & $-19,717$ & 54,622 & 11,504 & $-43,118$ & 84,757 & 15,146 & $-69,611$ & 24,459 & 41,146 & $: 6,686$ \\
\hline Non-Cls & 311 & 3,397 & 3,086 & 676 & 4,308 & 3,632 & 1,115 & 3,086 & 1,970 & 8.200 & 90,984 & 82,783 \\
\hline Metallurgy & 10,789 & 5,354 & $-5,436$ & 27,792 & 15,475 & $-12,317$ & 55,796 & 31,449 & $-24,347$ & 218,961 & 105,017 & -112.944 \\
\hline cls & 8,667 & 3,105 & $-5,562$ & 21,896 & 10,109 & $-11,788$ & $44,5.11$ & 20,167 & $-24,344$ & 161,726 & 45,844 & $-115,882$ \\
\hline Nan-CIS & 1,922 & 2,049 & 126 & 5,896 & 5,366 & -530 & 11,285 & 11,282 & -3 & 57,235 & 60,174 & 2,938 \\
\hline Chemicals and perrochemicals & 15,294 & 16,952 & 1,659 & 38,802 & 40,440 & 1,638 & 70,955 & 79,765 & 8,811 & 606,205 & 353,885 & $.252,320$ \\
\hline $\operatorname{cis}$ & 8,062 & 8,086 & 24 & 20,378 & 22,054 & 1,677 & 37,876 & 45,012 & 7,136 & 478,757 & 159,117 & $-319,640$ \\
\hline Non-CIS & 7,232 & 8,877 & 1,645 & 18,425 & 18,385 & -39 & 33,079 & 34,753 & 1,674 & 127,448 & 194,768 & 67,320 \\
\hline Macline building and metal processing & 17,554 & 23,660 & 6,106 & 49,934 & 64,957 & 15,023 & 107,686 & 112,490 & 4,804 & 413,427 & 534,713 & 121,287 \\
\hline CIS & 7,366 & 18,054 & 10,686 & 26,231 & $\$ 4,230$ & 27,999 & 50,880 & 89,535 & 38,654 & $196,18 \mathrm{~L}$ & 401,128 & 204,947 \\
\hline Non-CIS & 10,188 & 5,597 & $-4,591$ & 23,703 & 10,727 & $-12,976$ & 56,806 & 22,956 & $-33,850$ & 217,246 & 133,586 & $-83,660$ \\
\hline Wood and paper & 2,379 & 4,255 & 1,877 & 6,436 & 13,732 & 7,296 & 13,323 & 25,711 & 12,389 & 54,232 & 103,565 & 49,133 \\
\hline $\mathrm{cls}$ & 1,205 & 3,193 & 1,987 & 3,616 & 11,332 & 7,716 & 7,295 & 19,769 & 12,474 & 33,204 & 66,853 & 33,649 \\
\hline Non-CIS & 1,173 & 1,062 & -110 & 2,820 & 2,399 & -420 & 6,027 & 5,942 & -86 & $2 !, 028$ & 36,712 & 15,683 \\
\hline Construction materials & 853 & 1,755 & 902 & 3,772 & 4,809 & 1,037 & 5.207 & 7,837 & 2,631 & 34,89 & 40,890 & $5,9,99$ \\
\hline $\mathrm{CIS}$ & 535 & 1,458 & 923 & 2,888 & $4,14.3$ & 1,254 & 2,723 & 6.369 & 3,646 & 25,762 & 30,182 & 4,421 \\
\hline Non-cts & 318 & 296 & .22 & 883 & $6 \pi 6$ & -217 & 2,483 & 1,468 & $-1,015$ & 9,130 & 10,618 & 1,488 \\
\hline Light industry & 3,935 & 6,107 & 2,172 & 10,584 & 18,289 & 7,705 & 18,477 & 35,042 & 16,564 & $96,39 !$ & 147,838 & 51,447 \\
\hline $\mathrm{CIS}$ & 916 & 3,127 & $2,2 \Downarrow 1$ & 4,855 & 12,120 & 7,264 & 7,441 & 21,037 & 13,596 & 33.080 & 86,689 & 53,609 \\
\hline Non-CIS & 2.719 & 2,680 & -39 & 5,729 & 6,170 & 441 & 11,036 & 14,005 & 2,969 & 63,311 & 61,149 & $-2,562$ \\
\hline Food-processing indusirjes & 8,180 & 5,648 & $-2,532$ & 22,093 & 14,599 & $-7,494$ & 33.717 & 31,672 & $-2,045$ & 175,541 & $1] 0,2] f$ & $-65,327$ \\
\hline CIS & 3,131 & 5,438 & 2,307 & $9,5,33$ & 13,955 & 4,423 & 14,211 & 30,264 & 16,053 & 84,692 & 96,400 & 11,709 \\
\hline Non-CIS & 5,046 & 210 & $-4,835$ & 12,561 & 644 & $-11,917$ & 19,506 & 1,409 & $-18,097$ & 90,849 & 13,814 & $.77,035$ \\
\hline Other industry & 1,286 & 1,054 & -231 & 2,602 & 1,628 & -974 & 8,300 & 14,202 & 5,902 & 12,044 & 6,016 & $-6,028$ \\
\hline cis & 859 & 658 & $-20 !$ & 1,619 & 767 & -852 & 6,496 & 2,560 & $-3,936$ & 10,014 & 4,006 & $-6,003$ \\
\hline Non-CIS & 427 & 397 & -30 & 983 & 861 & -122 & 1,804 & 11,642 & 9,838 & 2,030 & 2,011 & -20 \\
\hline Agriculnure & 4,566 & 1,467 & $-3,098$ & 8,465 & 3,273 & $.5,193$ & 12,299 & 4,645 & $-7,654$ & 73,371 & $27,10 ?$ & $-46,264$ \\
\hline CIs & 3,363 & 676 & $-2,687$ & 5,000 & 2,368 & $-2,632$ & 7,259 & 2,593 & $-4,660$ & 44,934 & 24,360 & $.20,574$ \\
\hline Non-ClS & 1,209 & 797 & -412 & 3,466 & 905 & $-2,561$ & 5,046 & 2,052 & $-2,994$ & 28,437 & 2,747 & $-25,690$ \\
\hline Other activities & 56 & 43 & .13 & i & I & 0 & 5.707 & 3,209 & $-2,498$ & $22,96 \mathrm{l}$ & 12,385 & $-10,576$ \\
\hline CIS & 37 & 30 & .7 & $i$ & 1 & 0 & 5,259 & 3,207 & $-2,052$ & 21,202 & 12,323 & $-8,879$ \\
\hline Non-CIS & 19 & 13 & -6 & 0 & 0 & 0 & 448 & 2 & -446 & 1,760 & 63 & $-1,697$ \\
\hline
\end{tabular}


Table 43. Belarus: Balance of Payments, 1996-2000 (Q1)

(In millions of U.S. dollars, unless otherwise indicated)

\begin{tabular}{|c|c|c|c|c|c|}
\hline & 1996 & 1997 & 1998 & 1999 & $\frac{2000}{Q^{1}}$ \\
\hline Current account balance & -515.9 & -787.6 & -865.5 & -256.7 & -138.0 \\
\hline Merchandise trade balance & $-1,148.5$ & $-1,335.4$ & $-1,350.1$ & -598.5 & -296.3 \\
\hline Exports & $5,790.1$ & $7,382.6$ & $7,138.1$ & $5,949.3$ & $1,678.8$ \\
\hline Imports & $-6,938.6$ & $-8,718.0$ & $-8,488.2$ & $-6,547.8$ & $-1,975.1$ \\
\hline Services (net) & 572.1 & 554.0 & 481.9 & 298.0 & 132.6 \\
\hline Receipts & 908.0 & 918.8 & 925.1 & 733.8 & 223.2 \\
\hline Payments & -335.9 & -364.8 & -443.2 & -435.8 & -90.6 \\
\hline Income (net) & -30.8 & -84.6 & -92.9 & -64.6 & -1.1 \\
\hline Receipts & 74.1 & 31.2 & 26.8 & 29.0 & 6.1 \\
\hline Payments & -104.9 & -115.8 & -119.7 & -93.6 & -7.2 \\
\hline Transfers (net) & 91.3 & 78.4 & 95.6 & 108.4 & 26.8 \\
\hline Capital and financial accounts & 447.9 & 719.7 & 470.9 & 309.7 & -101.0 \\
\hline Capital account & 101.1 & 133.2 & 170.1 & 60.4 & 15.0 \\
\hline Financial account & 346.8 & 586.5 & 300.8 & 249.3 & -116.0 \\
\hline Direct investment (net) & 72.6 & 197,9 & 146.9 & 224.2 & 8.5 \\
\hline Portfolio investment (net) & -14.5 & -19.8 & 14.6 & -32.2 & 4.8 \\
\hline Trade Credits (net) & 93.2 & 418.6 & 128.2 & 46.7 & -55.8 \\
\hline Loans (net) & 76.9 & 72.4 & 12.5 & 26.7 & 37.1 \\
\hline Assets & 0.0 & -4.2 & 7.1 & -7.0 & -1.3 \\
\hline Liabilities & 76.9 & 76.6 & 5.4 & 33.7 & 38.4 \\
\hline General govemment & 33.4 & 62.4 & 24.7 & -41.5 & 12.2 \\
\hline Disbursements & 108.3 & 138.2 & 90.7 & 59.4 & 32.2 \\
\hline Amortization & -74.9 & -75.8 & -66.0 & -100.9 & -20.0 \\
\hline Other Sectors & 43.5 & 14.2 & -19.3 & 75.2 & 26.2 \\
\hline Other (net) & 118.6 & -82.6 & -1.4 & -16.1 & -110.6 \\
\hline Assets & -37.6 & -5.5 & 4.4 & -4.5 & -78.1 \\
\hline Liabilities & 156.2 & -77.1 & -5.8 & -11.6 & -32.5 \\
\hline Errors and omissions & -146.2 & 132.9 & 75.3 & 34,3 & 183.3 \\
\hline Overall balance & -214.2 & 65.0 & -319.3 & 87.3 & -55.7 \\
\hline Financing & 214.2 & -65.0 & 319.3 & -87.3 & 55.7 \\
\hline Gross official reserves $1 /$ & -78.6 & 75.4 & 54.6 & 34.5 & 2.9 \\
\hline Use of Fund resources & 0.0 & 0.0 & -24.4 & -58.0 & -24.3 \\
\hline Exceptional financing $2 /$ & 292.8 & -140.4 & 289.1 & -63.8 & 77.1 \\
\hline \multicolumn{6}{|l|}{ Memorandum items: 3} \\
\hline Current account (as percent of GDP) & -3.7 & -5.8 & -6.1 & -2.2 & -4.2 \\
\hline Trade balance (as percent of GDP) & -8.3 & -9.8 & -9.5 & -5.2 & -9.1 \\
\hline Overall balance (as percent of GDP) & -1.5 & 0.5 & -2.2 & 0.8 & -1.7 \\
\hline Gross convertible official reserves $4 /$ & 369.2 & 393.7 & 345.0 & 309.0 & 294.0 \\
\hline In months of imports of goods & 0.6 & 0.5 & 0.5 & 0.6 & $\ldots$ \\
\hline Medium and long-term debt 5 ' & 950.0 & 976.0 & 1011.0 & 886.0 & 859.0 \\
\hline (as percent of GDP) & 6.8 & 7.2 & 7.1 & 7.7 & $\ldots$ \\
\hline Short-term debt $6 /$ & 997.7 & 1173.3 & 1472.0 & 1508.3 & $\ldots$ \\
\hline (as percent of GDP) & 7.2 & 8.6 & 10.3 & 13.1 & $\ldots$ \\
\hline Debt service ratio $7 i$ & 2.3 & 2.0 & 1.8 & 3.1 & 2.6 \\
\hline (cxcluding bartered exports) & 2.7 & 3.0 & 2.7 & 4.9 & $\ldots$ \\
\hline Export Value Index (annual percentage change) & 20.6 & 27.5 & -3.3 & -16.7 & 26.7 \\
\hline Import Value Index (antmal percentage change) & 26.9 & 25.6 & -2.6 & -22.9 & 43.1 \\
\hline
\end{tabular}

Sources: Belarusian authorities; and Fund staff estimates.

$1 /$ Adjusted for valuation changes.

2/ Includes accumulation, repayment, and forgiveness of arrears.

3/ Ratios for 1999 reflect the steep devaluation of the exchangc rate.

4/ End-1996 figure is adjusted for exceptional short-term credits.

5/ Refers to public and publicly-guaranteed debt only. The 1996 figure reflects the cancellation by Russia of $\$ 471$ million in technical credits.

6/ Includes arrears and scheduled amortization payments falling due within the following year.

7/ Amortization and interest payments on public and publicly-guaranteed debt over exports of goods and services. 
Table 44. Belarus: Selected International Liabilities, 1996-2000 (Q1)

(In millions of U.S. dollars, unless otherwise indicated; end-of-period)

\begin{tabular}{|c|c|c|c|c|c|}
\hline & 1996 & 1997 & 1998 & 1999 & 2000 \\
\hline \multicolumn{6}{|l|}{ Total medium- and long-term public and publicly- } \\
\hline guaranteed external debt & 950 & 976 & 1,011 & 886 & 859 \\
\hline Multilateral (including IMF) & 500 & 532 & 548 & 449 & 416 \\
\hline IMF & 277 & 259 & 245 & 178 & 150 \\
\hline World Bank & 125 & 138 & 142 & 130 & 131 \\
\hline EBRD & 61 & 102 & 126 & 111 & 106 \\
\hline European Union & 37 & 33 & 35 & 30 & 29 \\
\hline Bilateral & 450 & 444 & 463 & 437 & 443 \\
\hline \multicolumn{6}{|l|}{ Of which: } \\
\hline Russia 1/ & 14 & 65 & 90 & 81 & 75 \\
\hline United States & 86 & 86 & 86 & 85 & 84 \\
\hline Germany & 277 & 206 & 194 & 166 & 161 \\
\hline Japan & 39 & 30 & 32 & 32 & 32 \\
\hline Total short-term external debt (end-of period) & 918 & 1,070 & 1,284 & 1,309 & 1,331 \\
\hline Trade credits & 338 & 697 & 637 & 706 & 661 \\
\hline Liabilities of the banking system & 244 & 159 & 139 & 116 & 104 \\
\hline Arrears & 297 & 156 & 447 & 386 & 462 \\
\hline \multicolumn{6}{|l|}{ Of which: } \\
\hline Gas & 203 & 94 & 243 & 234 & 304 \\
\hline Oil & 39 & 39 & 59 & 19 & 10 \\
\hline Electricity & 31 & 21 & 129 & 96 & 107 \\
\hline Otber & 40 & 58 & 60 & 102 & 104 \\
\hline
\end{tabular}

Sources: Belarusian authorities; and Fund staff estimates.

1/ Fund staff estimate on an annualized basis. 
Table 45. Belans: Disbursements and Payments on Medium- and Long-term Public and Publicly-guaranteed Debt, 1997-2001 (In millions of U.S. dollars; end of period)

\begin{tabular}{|c|c|c|c|c|c|}
\hline & 1997 & 1998 & 1999 & 2000 & 2001 \\
\hline & \multicolumn{2}{|c|}{ Actual } & \multicolumn{3}{|c|}{ Projection } \\
\hline \multicolumn{6}{|c|}{ Disbursements of medium- and long-term pubiic and publicly- } \\
\hline guaranteed debt, excluding IMF & 138 & 90 & 39 & 78 & 35 \\
\hline Multilateral (Official) & 63 & 42 & 6 & 8 & 0 \\
\hline World Bank: & 13 & 4 & 1 & 3 & 0 \\
\hline EBRD & 50 & 38 & 5 & 5 & 0 \\
\hline European Union & 0 & 0 & 0 & 0 & 0 \\
\hline Bilateral (Official) & 75 & 48 & 33 & 70 & 35 \\
\hline Russia & 52 & 29 & 3 & 0 & 0 \\
\hline Germany & 11 & 11 & 11 & 20 & 10 \\
\hline Other & 12 & 8 & 19 & 50 & 25 \\
\hline Other creditors & 0 & 0 & 0 & 0 & 0 \\
\hline \multicolumn{6}{|c|}{ Payments on existing stock of medium- and long-term public } \\
\hline and publicly-guaranteed debt, including IMF & 129 & 137 & 189 & 219 & 187 \\
\hline Principal & 66 & 86 & 140 & 170 & 145 \\
\hline Interest & 63 & 51 & 49 & 49 & 42 \\
\hline IMF & 16 & 37 & 69 & 65 & 36 \\
\hline Principal & 0 & 25 & 58 & 58 & 32 \\
\hline Interest & 16 & 12 & 11 & 7 & 4 \\
\hline World Bank & 8 & 8 & 21 & 26 & 25 \\
\hline Principal & 0 & 0 & 13 & 17 & 17 \\
\hline Initerest & 8 & 8 & 8 & 9 & 8 \\
\hline EBRD & 14 & 27 & 25 & 27 & 27 \\
\hline Principal & 7 & 18 & 15 & 18 & 19 \\
\hline Interest & 7 & 9 & 10 & 9 & 8 \\
\hline Bilateral and EU & 91 & 65 & 74 & 101 & 99 \\
\hline Principal & 59 & 43 & $\$ 4$ & 77 & 77 \\
\hline Interest & 32 & 22 & 20 & 24 & 22 \\
\hline
\end{tabular}

Source: Belarusian authorities. 
Table 46. Belarus: Gas Supply and Arrears, 1997-2000 (March)

(In millions of U.S. dollars; end-perjod stocks)

\begin{tabular}{|c|c|c|c|c|c|c|}
\hline & \multirow[b]{2}{*}{ Cost of gas supplied } & \multirow[b]{2}{*}{$\begin{array}{l}\text { Total stock of arrears } \\
\text { for gas supplied } 1 /\end{array}$} & \multicolumn{2}{|c|}{ Orwhich: } & \multirow[b]{2}{*}{$\begin{array}{l}\text { Supply of natural } \\
\text { gas (in } \\
\text { millions of } \mathrm{m} 3 \text { ) }\end{array}$} & \multirow[b]{2}{*}{$\begin{array}{l}\text { Net prica } \\
\text { (USS per } \\
\text { thousand m3) }\end{array}$} \\
\hline & & & $\begin{array}{l}\text { Arrears to } \\
\text { Gazpron }\end{array}$ & $\begin{array}{l}\text { Arrears to other } \\
\text { cieditors }\end{array}$ & & \\
\hline 1997 Dec & 70.0 & 237.1 & 94.4 & 122.7 & 1,427 & 49.06 \\
\hline $1998 \mathrm{Jan}$ & 85.9 & 222.2 & 156.4 & 65.8 & 1,719 & 49.97 \\
\hline Feb & 75.6 & 241.3 & 181.4 & 59.9 & 1,512 & 50.02 \\
\hline Mar & 69.6 & 259.3 & 210.9 & 48.4 & 1,391 & 50.03 \\
\hline Apr & 59.8 & 277.6 & 206.9 & 70.7 & 1,195 & 50.04 \\
\hline May & 58.3 & 291.1 & 226.4 & 64.7 & 1,149 & 50.74 \\
\hline Jun & 45.4 & 305,8 & 241.1 & 64.7 & 895 & 50.73 \\
\hline Jul & 49.9 & 313.8 & 238.5 & 75.3 & 982 & 50.81 \\
\hline Aug & 49.5 & 312,1 & 205.6 & 106.5 & 973 & 50.87 \\
\hline Sep & $\$ 4.4$ & 290.9 & 212.5 & 78.4 & 1,069 & 50.89 \\
\hline Oct & 76.7 & 306.5 & 241.9 & 64.6 & 1,514 & 50.66 \\
\hline Nov & 82.1 & 333.8 & 290.2 & 43.6 & 1,620 & 50.68 \\
\hline Dec & 89.1 & 380.1 & 232.2 & 147.9 & 1,784 & 49.94 \\
\hline $1999 \mathrm{Jan}$ & 52.2 & 355.9 & 216.4 & 139.5 & 1,738 & 30.00 \\
\hline Feb & 44.4 & 336.0 & 245.2 & 90.8 & 1,479 & 30.00 \\
\hline Mar & 41.6 & 318.1 & 280.7 & 37.4 & 1,385 & 30.00 \\
\hline Apr & 37.8 & 302.5 & 273.1 & 29.4 & 1,261 & 30.00 \\
\hline May & 34.8 & 298.6 & 273.1 & 25.5 & $1,16 !$ & 30.00 \\
\hline Jun & 31.3 & 310.0 & 286.6 & 23.4 & 1,029 & 30.46 \\
\hline Jul & 32.1 & 307.9 & 272.5 & 35.4 & 1,049 & 30.51 \\
\hline Aug & 33.0 & 305.7 & 261.7 & 44.0 & 1,082 & 30.52 \\
\hline Sep & 34.5 & 317.2 & 259.0 & 58.2 & 1,135 & 30.41 \\
\hline $\mathrm{Oet}$ & 41.7 & 320.5 & 279.9 & 40.6 & 1,373 & 30.42 \\
\hline Nov & 49.0 & 266.1 & 218.1 & 48.0 & 1,634 & 30.00 \\
\hline Dec & 53.6 & 274.1 & 198.0 & 76.1 & 1,750 & 30.42 \\
\hline $2000 \mathrm{Jant}$ & 54.5 & 308.7 & 220.8 & 87.9 & 1,795 & 30.44 \\
\hline Feb & 50.5 & 316.7 & 238.6 & 78.1 & $\$, 653$ & 30.46 \\
\hline Mar & 52.8 & 326.4 & 236.6 & 89.8 & 1,731 & 30.48 \\
\hline
\end{tabular}

Source: Belanusian authorities.

1/ Arrears include penalties on arrears accumulated. 
Table 47. Belarus: Transformation of Property, 1996-2000 (Q1)

\begin{tabular}{|c|c|c|c|c|c|}
\hline & 1996 & 1997 & 1998 & 1999 & $\frac{2000}{Q 1}$ \\
\hline Number of privatized enterprises & 473 & 493 & 405 & 201 & 0 \\
\hline Cumulative since 1991 & 2,007 & 2,500 & 2,905 & 3,106 & 3,106 \\
\hline In percent of total eligible for privatization & 11 & 11 & 67 & 50 & 55 \\
\hline \multicolumn{6}{|l|}{ Transformed by activity } \\
\hline Industry & 37 & 80 & 62 & 29 & 0 \\
\hline Construction & 29 & 39 & 33 & 5 & 0 \\
\hline Agro-processing & 125 & 70 & 25 & 19 & 2 \\
\hline Transport & 25 & 26 & 7 & 3 & 5 \\
\hline Service & 41 & 44 & 49 & 31 & 0 \\
\hline Trade and catering & 210 & 232 & 151 & 102 & 1 \\
\hline Other & 44 & 67 & 78 & 12 & 2 \\
\hline \multicolumn{6}{|l|}{ Transformed by method } \\
\hline Conversion into joint-stock companies & 221 & 178 & 89 & 94 & 0 \\
\hline Buy-outs of leased enterprises & 58 & 76 & 53 & 33 & 0 \\
\hline Sale by corrpetitive bidding & 166 & 182 & 163 & 60 & 0 \\
\hline Sale in auctions & 42 & 41 & 24 & 14 & 0 \\
\hline Sale to individuals & 0 & 0 & 0 & 0 & 0 \\
\hline Saie to juridical persons & 0 & 0 & 0 & 0 & 0 \\
\hline
\end{tabular}

Source: Ministry for the Management of State Property and Privatization. 
Table 48. Belarus: Housing Privatization, 1996-2000 (Q1) 1/

\begin{tabular}{|c|c|c|c|c|c|}
\hline & 1996 & 1997 & 1998 & 1999 & $\frac{2000}{\mathrm{Q} 1}$ \\
\hline & \multicolumn{5}{|c|}{ (In thousandis) } \\
\hline Number of apartments privatized during the period & 75 & 77 & 86 & 192 & 25 \\
\hline Cumulative number of apartments privatized since 1989 & 701 & 778 & 864 & 1,056 & 1,081 \\
\hline \multirow[t]{2}{*}{ In percent of total government and public owned } & 6 & 6 & 7 & 18 & 2 \\
\hline & \multicolumn{5}{|c|}{ (In mitlions of square meters) } \\
\hline Amount of housing privatized & 4 & 4 & 4 & 10 & 1 \\
\hline Cumulative number of apartments privatized since 1989 & 37 & 41 & 45 & 55 & 57 \\
\hline Average size of privatized apartments & 51 & 51 & 52 & 53 & 54 \\
\hline
\end{tabular}

Source: Ministry of Statistics and Analysis.

1/ The total number of dwelling units that had been privatized during 1989-98 corresponds to 44 percent of the total stock of govemment and publicly-owned housing. Adding annual percentages will give a different result due to expansion of the housing stock during this period. 